Andrews University

Digital Commons @ Andrews University

2009

\title{
A Discipleship Model "Go and Make Disciples" for the Hispanic Hoover Seventh-day Adventist Church in Alabama
}

Ezequiel Osorio

Andrews University

Follow this and additional works at: https://digitalcommons.andrews.edu/dmin

Part of the Practical Theology Commons

\section{Recommended Citation}

Osorio, Ezequiel, "A Discipleship Model "Go and Make Disciples" for the Hispanic Hoover Seventh-day Adventist Church in Alabama" (2009). Professional Dissertations DMin. 582.

https://dx.doi.org/10.32597/dmin/582

https://digitalcommons.andrews.edu/dmin/582

This Project Report is brought to you for free and open access by the Graduate Research at Digital Commons @ Andrews University. It has been accepted for inclusion in Professional Dissertations DMin by an authorized administrator of Digital Commons @ Andrews University. For more information, please contact repository@andrews.edu. 


\begin{abstract}
A DISCIPLESHIP MODEL "GO AND MAKE DISCIPLES" FOR THE HISPANIC HOOVER SEVENTH-DAY ADVENTIST CHURCH IN ALABAMA
\end{abstract}

by

Ezequiel Osorio

Adviser: Michael Steenhoven 


\title{
ABSTRACT OF GRADUATE STUDENT RESEARCH
}

Dissertation

\author{
Andrews University \\ Seventh-day Adventist Theological Seminary
}

Title: A DISCIPLESHIP MODEL "GO AND MAKE DISCIPLES" FOR THE HISPANIC HOOVER SEVENTH-DAY ADVENTIST CHURCH IN ALABAMA

Name of researcher: Ezequiel Osorio

Name and degree of faculty: Michael Steenhoven, D.Min.

Date completed: April 2009

\section{Statement of the Problem}

The concept of discipleship is not well understood in Christendom including in the SDA church. Many churches are adding new converts to their membership, but these new converts are not being trained and equipped to become true disciples. This phenomenon is having effect in the Hoover Hispanic Seventh-day Adventist Church (HHSDA $)^{1}$. A better understanding of the discipleship concept is necessary, for that reason, a discipleship seminar named "Go and Make Disciples" was created for the members at HHSDA. 
Method

A seminar method was used in this project. The researcher used the sanctuary of the HHSDA church as the classroom. A seminar manual, based on the literature studied, was designed. Two sources of literature were considered: (1) literature dealing with methods of discipleship, and (2) literature dealing with a biblical and theological understanding of discipleship. The duration of the seminar was five days, with two hours for each session. Approximately 30 members between ages 18-50 years old participated in the seminar. Two questionnaires were given to the participants, one before the seminar to evaluate the understanding of discipleship and another thirty days after the conclusion of the seminar.

Results

The results showed that the participants acquired a better understanding of discipleship and the difference between a disciple and a believer. They were encouraged to work more faithfully in the preaching of the gospel. Following Jesus' model, four groups of twelve with their leaders were formed. Each participant set a goal of reaching two souls for Jesus

\section{Conclusion}

The preaching of the gospel is not going to be concluded until the members recognize the importance of the Great Commission given by Jesus. For that reason it is imperative to continue teaching, training, and equipping the saints for the task of mission. 
Andrews University

Seventh-day Adventist Theological Seminary

\title{
A DISCIPLESHIP MODEL "GO AND MAKE DISCIPLES" FOR THE HISPANIC HOOVER SEVENTH-DAY ADVENTIST CHURCH IN ALABAMA
}

\author{
A Dissertation \\ Presented in Partial Fulfillment \\ of the Requirements for the Degree \\ Doctor of Ministry
}

by

Ezequiel Osorio

April 2009 
(C) Copyright by Ezequiel Osorio 2009 All Rights Reserved 


\title{
A DISCIPLESHIP MODEL "GO AND MAKE DISCIPLES"
}

FOR THE HISPANIC HOOVER SEVENTH-DAY

ADVENTIST CHURCH IN ALABAMA

\author{
A dissertation \\ presented in partial fulfillment \\ of the requirements for the degree \\ Doctor of Ministry
}

by

Ezequiel Osorio

APPROVAL BY THE COMMITTEE:
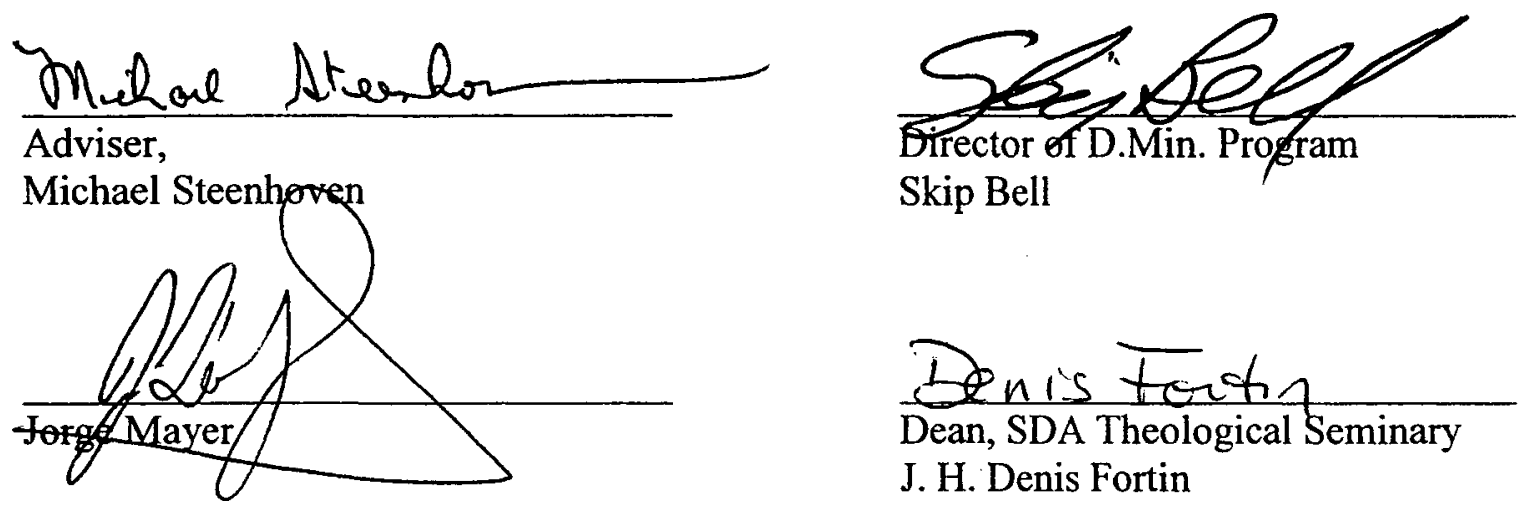

Skip Bell
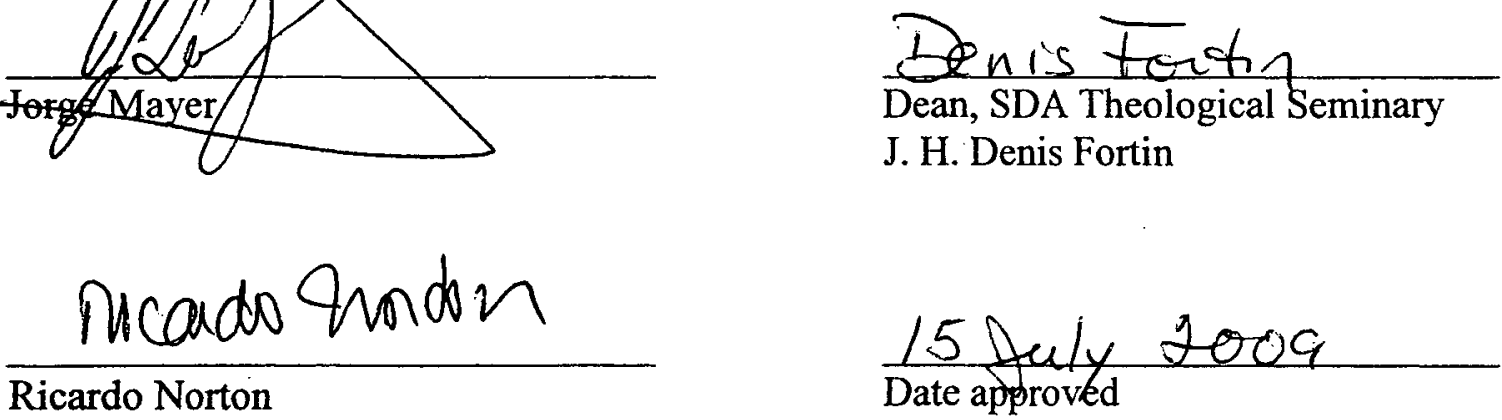

J. H. Denis Fortin

Ricardo Norton

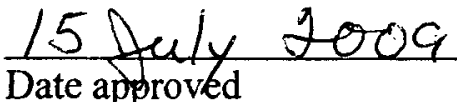




\section{DEDICATION}

This dissertation is dedicated with all my love to: my parents Jose Victor Osorio and Maria Audelia Gonzalez, my brothers and sisters, my dear wife Maria Gabriela, and my beloved children Marianela, Flor de Maria and Edgar David. 


\section{TABLE OF CONTENTS}

TABLE OF FIGURES $\ldots \ldots \ldots \ldots \ldots \ldots \ldots \ldots \ldots \ldots \ldots \ldots \ldots \ldots \ldots \ldots \ldots \ldots \ldots$ vii

ACKNOWLEDGMENTS $\ldots \ldots \ldots \ldots \ldots \ldots \ldots \ldots \ldots \ldots \ldots \ldots \ldots$ viii

Chapter

1. INTRODUCTION TO THE PROJECT $\ldots \ldots \ldots \ldots \ldots \ldots \ldots \ldots$

Statement of the Problem ..................... 1

Justification for the Dissertation $\ldots \ldots \ldots \ldots \ldots \ldots \ldots \ldots$. 5

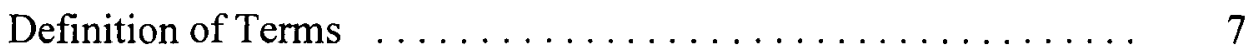

Limitations of the Project $\ldots \ldots \ldots \ldots \ldots \ldots \ldots \ldots \ldots \ldots$

Description of the Dissertation Process $\ldots \ldots \ldots \ldots \ldots \ldots \ldots .6$

Expectations of the Dissertation .................. 9

2. THEOLOGICAL FOUNDATIONS FOR DISCIPLESHIP $\ldots \ldots \ldots, 11$

Linguistic Terminology for Discipleship $\ldots \ldots \ldots \ldots \ldots \ldots \ldots \quad 11$

Old Testament Terms for Discipleship . . . . . . . . . . . 15

Talmid .................................. 15

Limmûd .............................. 17

The Intertestamental Background $\ldots \ldots \ldots \ldots \ldots \ldots \ldots \ldots, 17$

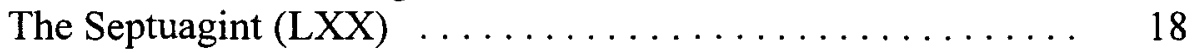

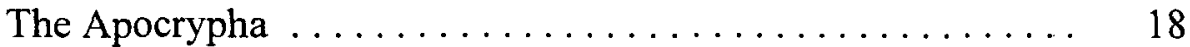

The Qumram Literature . . . . . . . . . . . . . . . . . . . . 19

Other Disciples in the Gospels $\ldots \ldots \ldots \ldots \ldots \ldots \ldots \ldots .20$

Disciples of John the Baptist $\ldots \ldots \ldots \ldots \ldots \ldots \ldots .20$

Disciples of the Pharisees ..................... 21

The Disciples of Moses $\ldots \ldots \ldots \ldots \ldots \ldots \ldots \ldots \ldots . \ldots \ldots$

Early Disciples of Jesus Who Left Him ............ 22

The New Testament Background $\ldots \ldots \ldots \ldots \ldots \ldots \ldots \ldots, 22$

The Concept of Discipleship $\ldots \ldots \ldots \ldots \ldots \ldots \ldots \ldots . \quad 22$

The Twelve .......................... 23

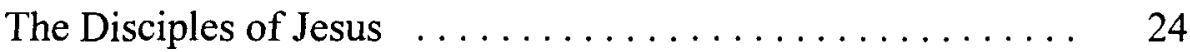

Jesus' Method of Making Disciples $\ldots \ldots \ldots \ldots \ldots \ldots \ldots \ldots \cdot 25$

Men Were His Method ...................... 25

Jesus' Strategy in Recruiting Disciples $\ldots \ldots \ldots \ldots \ldots \ldots 26$

Jesus' Training Strategy ...................... 27 
The Concept of Discipleship in Ellen G. White Writings . . . . . 29

Understanding the Great Commission $\ldots \ldots \ldots \ldots \ldots \ldots . \quad 30$

Conclusion $\ldots \ldots \ldots \ldots \ldots \ldots \ldots \ldots \ldots \ldots \ldots, 35$

3. CHARACTERISTICS OF A DISCIPLE $\ldots \ldots \ldots \ldots \ldots \ldots \ldots \ldots \ldots$

Jesus' Insight of a Disciple .................... 37

Brief Discussion of Jesus' Insight of a Disciple . . . . . . . . 38

Marks of a Disciple ...................... 46

The First Mark of a Disciple: Daily Prayer . . . . . . . 47

The Second Mark of a Disciple: Worship $\ldots \ldots \ldots \ldots \ldots .48$

The Third Mark of a Disciple: Bible Reading . ........ 49

The Fourth Mark of a Disciple: Service ............ 50

The Fifth Mark of a Disciple: Spiritual Friendship ....... 51

The Sixth Mark of a Disciple: Giving $\ldots \ldots \ldots \ldots \ldots \ldots .65$

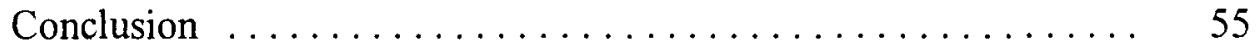

4. STUDY OF DISCIPLESHIP MODELS $\ldots \ldots \ldots \ldots \ldots \ldots \ldots$

Jesus' Model of Discipleship $\ldots \ldots \ldots \ldots \ldots \ldots \ldots \ldots \ldots \ldots$

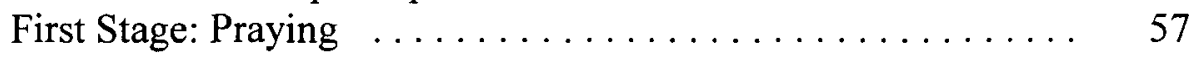

Second Stage: Choosing ................. 59

Third Stage: Invitation, "Tell Them What" and "Tell

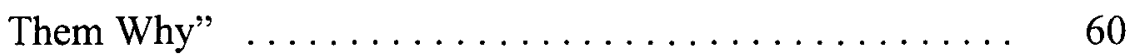

Fourth Stage: Training, "Show Them How" and "Do It with Them" $\ldots \ldots \ldots \ldots \ldots \ldots \ldots \ldots \ldots \ldots . \ldots \ldots$

Fifth Stage: Empowering, the Promise of the Holy Spirit .... 67

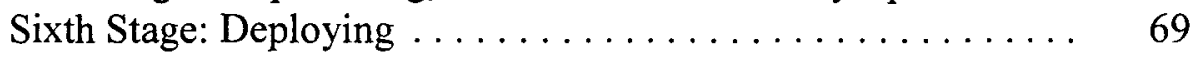

The Pauline Model ....................... 70

Discipleship Pyramid ...................... $\quad 70$

Contemporary Models of Discipleship .............. 71

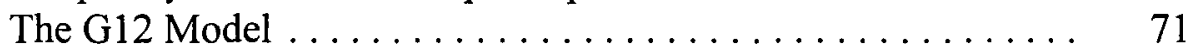

The $G 12$ Principle ...................... 73

Methodology of Model G12 ................ 73

The Method of Four Stages in G12 Model . . . . . . . . . 74

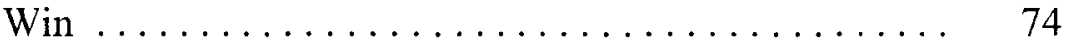

Consolidate ............................ 74

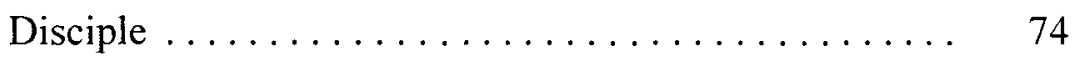

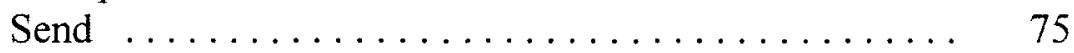

Factors of Growth of G12 Model . . . . . . . . . . . . . $\quad 75$

Some Critics of G12 Model .................... $\quad 76$

The Jethro Model $\ldots \ldots \ldots \ldots \ldots \ldots \ldots \ldots \ldots \ldots$

The Jethro Structure $\ldots \ldots \ldots \ldots \ldots \ldots \ldots \ldots \ldots . \quad 79$

The 5 X 5 Structure .................... 79

The Cell Group in the Jethro Structure .......... 79 
The Sub Zone $\ldots \ldots \ldots \ldots \ldots \ldots \ldots \ldots \ldots \ldots \ldots$

The Zone .......................... 81

The District ....................... 82

Basic Principles of the $5 \times 5$ Model $\ldots \ldots \ldots \ldots \ldots \quad 82$

Conclusion $\ldots \ldots \ldots \ldots \ldots \ldots \ldots \ldots \ldots \ldots \ldots, 83$

5. THE PRESENTATION OF THE SEMINAR "GO AND MAKE DISCIPLES” AT HHSDA CHURCH IN BIRMINGHAM ........ 84

History of the Church ....................... 84

Presentation of the Seminar "Go and Make Disciples" ........ 85

Phase 1: Preparation ...................... 85

Phase 2: The Presentation of the Discipleship Seminar

"Go and Make Disciples" . . . . . . . . . . . . . $\quad 88$

Purpose ............................ 88

Objectives ........................ 88

The Seminar Lessons $\ldots \ldots \ldots \ldots \ldots \ldots \ldots \ldots$

The Dynamic of Presentation ................ 90

Timetable of the Presentations $\ldots \ldots \ldots \ldots \ldots \ldots \ldots . \quad 90$

Summary of Each Presentation . . . . . . . . . . . . 90

Phase 3: Organizing the Church $\ldots \ldots \ldots \ldots \ldots \ldots \ldots .94$

Levels of Discipleship $\ldots \ldots \ldots \ldots \ldots \ldots \ldots \ldots \ldots$

Matrix-Cell ......................... 96

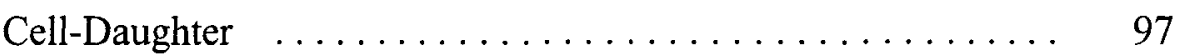

Conclusion $\ldots \ldots \ldots \ldots \ldots \ldots \ldots \ldots \ldots \ldots \ldots \ldots \ldots \ldots \ldots \ldots$

6. SUMMARY AND RECOMMENDATIONS $\ldots \ldots \ldots \ldots \ldots \ldots .100$

Summary ............................ 100

Experience and Results during the Seminar . . . . . . . . . 104

Results .............................. 105

Recommendations ......................... 106

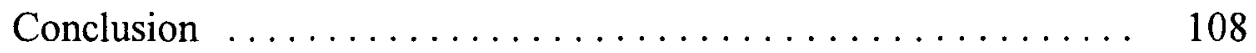

Appendix

A. SEMINAR LESSONS $\ldots \ldots \ldots \ldots \ldots \ldots \ldots \ldots \ldots \ldots \ldots \ldots$

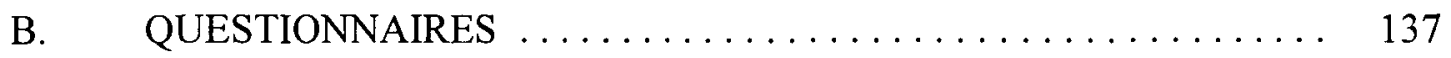

C. EVALUATIONS AND RESULTS $\ldots \ldots \ldots \ldots \ldots \ldots \ldots \ldots . \ldots \ldots 2$

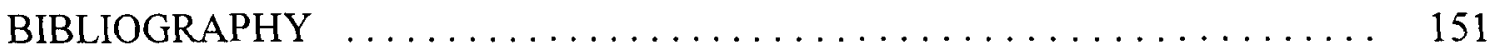

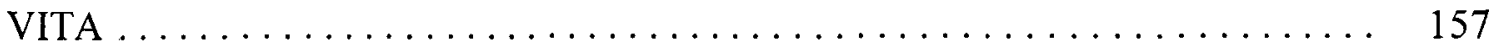




\section{LIST OF FIGURES}

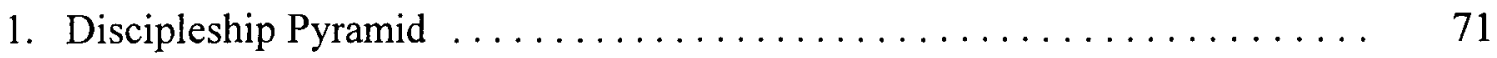

2. Sub-Zone Supervisor $\ldots \ldots \ldots \ldots \ldots \ldots \ldots \ldots \ldots \ldots \ldots \ldots \ldots \ldots \ldots \ldots$

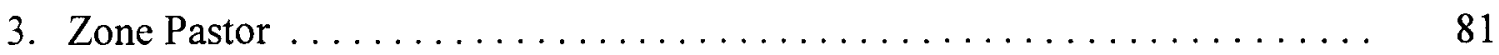

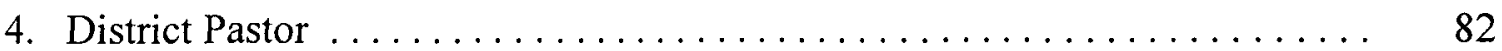

5. Difference between a Disciple and a Believer $\ldots \ldots \ldots \ldots \ldots \ldots \ldots . . \ldots 1$

6. Four Levels of Discipleship $\ldots \ldots \ldots \ldots \ldots \ldots \ldots \ldots \ldots \ldots \ldots$

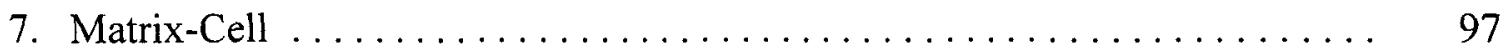

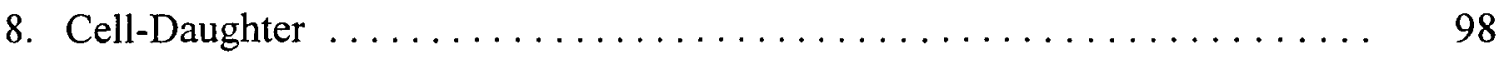




\section{ACKNOWLEDGEMENTS}

I want to acknowledge and express my gratitude to God our Heavenly Father and His Son Jesus Christ for allowing me to reach this level of my life. I want to recognize that without the direction of the Holy Spirit it would not be possible to fulfill my goals and dreams.

I wish to express my gratefulness to Dr. Kenley Hall, D.Min. Program Project Coach, for his support and guidance toward the completion stage of this task. Also to Dr. Michael Steenhoven and Dr. Jorge Mayer, members of my advisory committee, who spent many hours reading the manuscript and sharing their insights.

I also want to give thanks to all my teachers in the D.Min. program, especially to Dr. Alfonso Valenzuela and Dr. Ricardo Norton for their inspiration. My gratitude to Bonnie Beres, and Vanessa Pahm for their help in correcting and editing the manuscript.

Finally, I want to give my deepest gratitude to my wife Gabriela Osorio, for her support and understanding in order that I could achieve my objectives. My gratitude is also extended to my dear three children: Marianela, Flor de Maria, and Edgar David; they were my inspiration to finish this project. 


\section{CHAPTER 1}

\section{INTRODUCTION TO THE PROJECT}

\section{Statement of the Problem}

The concept of discipleship is not well understood in Christendom including in the SDA church. The HHSDA church needs a discipleship program that can help the members to understand the concept of discipleship in order to fulfill the Great Commission "Go and make disciples" which is the core of church growth. Discipleship and church growth are equally important. There is no church growth without discipleship and there is no discipleship without church growth. There is no doubt that God desires to see His church grow, not only numerically but also spiritually.

Bob Morehead says, "God intends His church to grow, He created it to grow, He designed it to grow, He equipped it to grow, He empowered it to grow. And, grow it did."1

The book of Acts tell us that the early church started with 120 disciples gathered in the upper room (Acts 1:13-15). When the Holy Spirit came to empower them to evangelize, as a result 3,000 people were baptized (Acts 2:41). From 3,000 the church grew to 5,000 (Acts 4:4), then on to "multitudes" (Acts 5:14).

The reason of this spectacular growth in the apostolic church was that the

'Bob Moorehead, The Growth Factor (Joplin, MO: College Press Publishing Company, 1991), 24. 
disciples were committed to do what Christ told them to do. They preached empower by the Holy Spirit and in a few years they had won thousands of people for the Kingdom of heaven.

Peter Wagner says, "The Bible is in favor of church growth,", so the question is, Why is the church not growing, as it should be? While the world population is growing fast, the church needs to do something to reach the multitudes. Wagner establishes two principles in church growth; the first is "the pastor must want the church to grow and be willing to pay the price," and the second is "the people must want the church to grow and be willing to pay the price."3

The price both church members and pastors should pay is the price of sacrifice and commitment, this includes time and resources. Therefore, the first reason why the church is not growing as it should is because both members and pastors are having problems in paying the price.

As this problem relates to pastors, Wagner said that in a survey made by Larry Richards 5,000 pastors from different denominations were asked to prioritize "the greatest needs in strengthening the life and program of your church." The report stated that "Less than half of the pastors gave high priority to planning and implementing church growth. Rather than growth, their priorities were centered on maintenance. Many pastors feel that making the existing church members more comfortable is of higher importance than reaching the lost for Jesus Christ." ${ }^{.4}$

\footnotetext{
${ }^{2}$ Peter Wagner, Leading Your Church to Growth (Venture, CA: Regal Books, 1984), 19.

${ }^{3}$ Ibid., 44 .

${ }^{4}$ lbid.
} 
The second reason why the church is not growing is vital. This is that the church has not understood the core of the great commission. Matthew registered the last words of Jesus regarding the Great Commission: "All authority in heaven and on earth has been given to me. Therefore, go and make disciples of all nations, baptizing them in the name of the Father, and of the Son and of the Holy Spirit, and teaching them to obey everything I have commanded you. And surely I am with you always, to the very end of the age" (Matt 28:18-20, NIV).

Sometimes there is a false concept of evangelism. Evangelism is not only reaching people with the good news of salvation and bringing them to accept Christ as their Savior and Lord. Evangelism is making them disciples of Christ. Robert E. Coleman, commenting on the Great Commission, says:

The Great Commission of Christ given to His church summed it up in the command to 'make disciples of every creature' (Matt. 28:19). The word here indicates that the disciples were to go out into the world and win others who would come to be what they themselves were-disciples of Christ. This mission is emphasized even more when the Greek text of the passage is studied, and it is seen that the words 'go,' 'baptize,' and 'teach' are all participles, which derive their force from the one controlling verb 'make disciples.'

The emphasis in the above paragraph is to make disciples, because the only way to evangelize the world is through reproduction and multiplication. Bill Hull refers to this passage and says: "The imperative command of the text is make disciples. This is the formula for evangelizing the world and the methodology required to bring reproduction and multiplication to world mission. The great commission without multiplication is evangelism paralyzed from the neck down. By specifically commanding

\footnotetext{
${ }^{5}$ Robert E. Coleman, The Master Plan of Evangelism (Grand Rapids, MI: Fleming H. Revell, 1963), 108.
} 
the making of disciples, Jesus specified the work product of the church."

If it is true that the order "to make disciples" is vital in the reproduction process of the church, it is also true that, in order to accomplish this commitment, the church needs to be obedient to the word of Jesus.

Bill Hull comments on this principle saying, "'Teaching them to obey everything I have commanded you ...' refers to the Great Commission itself. Teaching the church to obey the Great Commission is a vital, but neglected, work. The question arises, if a church does not obey the great commission, is that church obeying God; is it an obedient church? No, it is not."?

The third reason why the church is not growing and not following the divine counsel is negligence. The disciple-making task has been neglected by many Western Christians as David Watson stated: "Christians in the West have largely neglected what it means to be disciples of Christ. The vast majority of Western Christian church members, pew-fillers, hymn-singers, sermon spirit-filled-charismatic are not true disciples of Christ."

The last reason is that many churches have lost their vision, as a result of not doing the right thing; the church is very busy solving peripheral problems, Watson says, "With all our reports, committees, conferences, seminars, missions, crusades, ecumenism, and liturgical reports, little attention has been given to the meaning of discipleship."9

${ }^{6}$ Bill Hull, The Disciple Making Pastor (Grand Rapids, MI: Fleming H. Revell, 1988), 52.

${ }^{7}$ Ibid., 53.

${ }^{8}$ David Watson, Called and Committed: World Changing Discipleship (Wheaton, IL: Harold Shaw Publishers, 1982), 2-3.

${ }^{9}$ Ibid., 4. 
The task to make disciples is a learning-teaching process. The pastor as a leader of the church has to teach, motivate, and encourage the membership to learn all about discipleship. It is understandable that the effort is not easy, but at the end it will be profitable.

\section{Justification for the Dissertation}

There are several reasons that justify this project. Being a pastor for more than twenty five years, I have seen the need that the church has in creating a program where all the members may be involved in discipleship. I consider the following reasons:

1. Jesus himself, before his ascension, ordered his disciples "Go and make disciples" (Matt 28:19). Making disciples is not a choice, it is a mandate of the Lord, and as it is discussed in chapter three of this dissertation, one of the characteristics of a disciple is to be obedient to the Lord. Unfortunately, the church has not understood the process of making disciples, and has focused her efforts in preaching, teaching and baptizing. At the same time, many new converts when they enter into the church, are neglected; as a result many of them go back to their old lifestyles.

2. One of the tasks of the church is to retain the new members. A discipleship program will help new members understand and accomplish this commission. The church members should comprehend that preaching, teaching, and baptizing are important, but maintaining the new members is the most important matter in soul winning. When the church baptizes a new member and that person remains in the church it is a real gain. However, if that new member leaves the church after being baptized, then the church is not growing. Imagine worldwide church membership if all the people who have been baptized were to remain, the church would be strong and healthy, but 
sometimes the statistics are alarming; the General Conference of SDA reported in 2007, more than 34 percent in losses..$^{10}$ It is imperative to find a way to help the SDA churches implement a method to keep from backsliding. Remaining in Jesus and in His word is the solution. And, this is also a true characteristic of a disciple.

3. One of the joys of doing missionary work is seeing the person with whom we have studied accept Christ in his/her life and enjoy the blessings of being a newborn Christian. When the church members experiment this sentiment they will appreciate the opportunity they have to work to enhance the kingdom of heaven.

4. Another reason to have a discipleship program in the church is that, through such programs, the members are going to grow in grace and knowledge as the apostle Peter says, "But grow in grace, and in the knowledge of our Lord and Savior Jesus Christ. To him be glory both now and forever. Amen" (2 Pet 3:18). The member who grows, bears fruits which are a healthy characteristic of a true disciple (John 15:8). The member who does not bear fruits is at risk of losing his salvation, but not because salvation is through works (John 15:6). Salvation is by faith, but the true disciple is the one who abides in Jesus bringing forth fruits for Christ's glory.

5. Because the HHSDA church was planted recently (2004), it is important to have a discipleship program so that the members can understand their role as disciples of Christ.

\footnotetext{
${ }^{10}$ World Church Statistics, http://www.adventiststatistics.org/view_Summary.asp?FieldAbr=GC (accessed April 23, 2009).
} 


\section{Definition of Terms}

Terms used in this project report and definitions as they apply to this report are as follows:

Christian Discipleship is a process of making disciples for Christ. It is a concept that was born when Jesus Christ hand-selected His first followers. Christian discipleship began, according to John's Gospel, the day after Jesus was baptized and continues today through the work of the Holy Spirit (John 1:35-39).

Disciple, by definition, is a convinced adherent of a school or individual. In the case of Jesus, His disciples were those who followed Him while He was on earth, as well as those who continue to follow Him and His teachings today.

Disciple-maker is a newborn Christian who is committed to follow Jesus as His Master, and is dedicated to make others disciples of Christ.

Discipleship is a process of introducing people to Jesus Christ, helping them to grow into spiritual maturity and helping them to be disciple-makers.

Discipleship Models refers to the different models of discipleship found in the Bible.

Discipleship Training is training the lay person to follow the teachings of Jesus specifically in the aspect of discipleship, and to prepare him/her to fulfill the Great Commission.

\section{Limitations of the Project}

This discipleship model was created to train and empower the lay people of the HHSDA church at Birmingham, Alabama. Therefore, this project applies to a specific 
culture. The Hispanic members in our churches tend to maintain their culture, language, and traditions.

That differentiates this church from other SDA churches, especially in those that use the English language. Moreover, this model can be adapted by other SDA churches with some modifications.

\section{Description of the Dissertation Process}

The preliminary steps in preparing this dissertation were reviewing the literature related to the topic of discipleship. The literature included the Bible, the writings of Ellen G. White, books from different authors, and articles on the issues that pertain to the subject.

The first week in September 2008, the church board had a meeting to approve the presentation of a seminar in discipleship. This seminar was to be given as soon the researcher was ready for the presentation. The seminar took place on January 16-21, 2009 , in the sanctuary of the HHSDA church. Two questionnaires were prepared to ascertain the knowledge of the members about discipleship. The content of the seminar "Go and Make Disciples" was prepared in five lessons. The following is an overview of each chapter.

Chapter 2 discusses the theological foundations for discipleship based primarily in the Bible, Ellen G White writings, and from the current literature. An exhaustive study was done on the meaning of the term disciple. This term was studied from the perspective of the Old Testament (OT), the intertestamental period, the New Testament (NT) epoch, and the apocrypha literature.

In chapter 3 , the characteristics of a disciple, in connection with Jesus' definition 
of a disciple, are discussed. Other characteristics presented by other authors are also discussed. The purpose is to present discipleship as the ideal model for the laity as shown by Jesus Christ and to present the discipleship model as the desirable direction of the church members in order for them to embrace the vision of evangelism and to fulfill the Great Commission.

Chapter 4 deals with various models of discipleship, models from the Bible and from other denominations. The purpose of studying these models is to extract the principles that can be applied to HHSDA church.

In chapter 5, the seminar of discipleship "Go and Make Disciples" was presented to the HHSDA church at Birmingham, with the purpose of training the lay people. This seminar was presented in five sessions, with a preparatory phase, a workshop phase, and an evaluation phase. In the preparatory phase, a survey was conducted to find out the level of understanding about the theory and practice of discipleship. In the second phase, a workshop was conducted to study more deeply the meaning of discipleship and the importance of practicing what was being learned. Lastly, the evaluation phase shows the results of all the processes of the project and how it helped the church members understand more fully their role in the church, not as simple hearers but as doers of the Lord's will.

The project ends with summary, conclusions, and recommendations.

\section{Expectations of the Dissertation}

The main goal of this project is to create awareness on the minds of the members at HHSDA Church in Birmingham, Alabama, regarding the theme of discipleship. The 
HHSDA church needs to move from a membership-model church to a discipleship-model church.

In achieving this goal, the church will increase its membership. The members will be more active in missionary work; therefore, they will grow in knowledge and spirituality and we will not see the tragedy of losing members due to lack of opportunities for being active workers for the Lord.

This project has the tools for training the church members in being more effective and fruitful.

This project might serve as a model for other Hispanic churches in Gulf States Conference, and beyond its frontiers. Above all, the purpose of this project is for the glory of the Lord. 


\section{CHAPTER 2}

\section{THEOLOGICAL FOUNDATIONS FOR DISCIPLESHIP}

\section{Linguistic Terminology for Discipleship}

When discussions on the term discipleship arise, many different answers can be found. "Contributing to this dilemma is the fact that the word 'discipleship' does not specifically exist in the New Testament," explains Michel Dixon. Nevertheless, different terminologies can be found for the word discipleship in the New Testament. Karl Rengstorf suggests the Greek word akolouthein (to follow) as an expression used instead of the word discipleship. ${ }^{2}$

"Disciple" and "Follower" are used synonymously in the New Testament. Richard N. Longenecker explains, "Disciple and follower were common expressions in the secular parlance of antiquity. Yet they seem not to have been widely used with religious significance in Jesus' day. 'Disciple' (mathētēs) appears at most only three times in the LXX (possibly at Jer 13:21;20:11;20:11;46:9, though with variant readings in each case in important manuscripts)."”

${ }^{1}$ Michael C. Dixon, "Discipleship in I Peter as a Model for Contextual Mission" (D.Min. dissertation, Southern Baptist Theological Seminary, 1989), 4.

${ }^{2}$ Karl H. Rengstorf, "Manthano," Theological Dictionary of the New Testament (Grand Rapids, MI: Eerdmans, 1965), 4:406.

${ }^{3}$ Richard N. Longenecker, Patterns of Discipleship in the New Testament (Grand Rapids, MI: Eerdmans, 1996), 2. 
The Greek word akolouthein (to follow) appears rarely in the LXX in a religious context. This word is used in the secular sense of physically following someone (cf. Num 23:20; 1 Kgs 16:22; Ruth 1:14; Isa 45:14; Hos 2:5). This word can also mean to accompany someone like an attendant (cf. 1 Sam 25:42). Longenecker adds further:

Both "disciple" and "follower," therefore, while common in secular parlance, seem also to have had some currency in the religious language of Jesus' day. The rabbinic writings, which codify earlier Jewish teachings and situations, reflect such a currency. And the increased frequency of these terms in our canonical Gospels and to some extent in Acts vis-à-vis their appearance in Paul's letters, which were written earlier, seems to suggest that this religious usage was increasing during the time the New Testament was written. ${ }^{4}$

Gerhard Kittel agrees that "distinctive statistical evidence shows that special use of akolouthein is strictly limited to discipleship of Christ." "The disciple leaves everything to go after Jesus (Mark 10:28; vf 1:8; 5:11). This

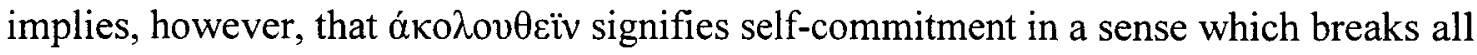
other ties (Matt 8:22; Luke 9:61 f.). The disciple does what the pupil of the Rabbi does, externally in the same forms as the latter, but internally in attachment to Jesus."

Longenecker says, "The verb 'to follow' (akolouthein) and its participle 'those who follow' (hoi akolouthountes) appears frequently in the Gospels with reference to the crowds who traipsed after and thronged around Jesus (Matt 4:25; 8:1; 12:15; 14:13; Mark 5:24; 10:32; 11:9; Luke 7:9; 9:11; John 6:2)." But these terms are also used several times by the evangelists in the religious sense of following Jesus as His disciples (Matt

${ }^{4}$ Ibid., 4.

${ }^{5}$ Gerhard Kittel, "Akoloutheo," Theological Dictionary of the New Testament (Grand Rapids, MI: Eerdmans, 1965), 1:213.

${ }^{6}$ Ibid., 1:213-14.

${ }^{7}$ Longenecker, 4. 
8:19; 9:9; Mark 1:18; 2:14; Luke 5:11, 27, 28; John 1:40, 43).

"This discipleship is essentially a religious gift. Discipleship means participation in the salvation offered in Jesus," adds Gerhard Kittel. ${ }^{8}$

Discipleship not only means a participation in the salvation offered by Christ, but also means sharing Jesus Christ's destiny. In the passages Matt 8:19-22, Mark 8:34-35, and John 12:25, 26, one can read that Jesus is telling His disciples and all of those who want to be His followers that it is imperative to have an exclusive fellowship with Him but also be willing to participate in His sufferings.

Perhaps the key word in understanding discipleship in the New Testament is the word disciple. This word is essential to our theological comprehension of discipleship. The translation of the word disciple in the New Testament frequently comes from the Greek word mathetes. Walton H. Rose Sr. says, "This word occurs two hundred and fifty times in the New Testament, but it can be found only in the Gospels and the Acts of the Apostles."9

Rengstorf says, "The word denotes the men who have attached themselves to Jesus as their Master." ${ }^{10}$ Being a disciple of Christ in the New Testament means to be a learner, pupil, apprentice, or adherent.

The Greek word mathetes (disciple) comes from the Greek verb manthano, which means to learn. The plural for mathetes (disciple) is mathetai (disciples). The gender for the Greek word mathetes is masculine, however, the term is also used in the feminine

${ }^{8}$ Kittel, 1:214.

${ }^{9}$ Walton H. Rose Sr., "The Use of Small Groups as an Element of Discipleship in the Fairhaven, Flint, Michigan, Seventh-day Adventist Church" (D.Min. dissertation, Andrews University, 1996), 8.

${ }^{10}$ Rengstorf, 4:441. 
form mathetria. The only passage where the feminine form mathetria can be found is Acts 9:36, referring to Tabitha of Joppa, whom Peter raised from the dead.

Another word which is related to discipleship in the New Testament is the Greek word mimetes. This word comes from the infinitive verb mimeomai that can be translated as a mimic or actor. The Expanded Vine's Expository Dictionary of New Testament Words says that this word is always translated "to imitate" in the Revised Version (RV), and the American Version (AV), to follow (a) imitating the conduct of missionaries (2 Thess 3:7, 9); the faith of spiritual guides (Heb 13:7); (b) that which is good (3 John 11). John R. Kohlenberg says, "The verb is always used in exhortations, and always in the continuous tense, suggesting a constant habit or practice."11 Moulton and Milligan explain, "It is noteworthy that in all its NT occurrences $\mu \iota \mu \epsilon \tau \epsilon \varsigma$ is joined with $\gamma \nu \iota \nu \epsilon \sigma \tau \eta \alpha^{\prime}$ denoting moral effort."12

The term mimetes is much used by the apostle Paul in his writings. He says, "Be ye imitators of me, even as I also am of Christ" (1 Cor 11:1). He adds, "I beseech you therefore, be ye imitators of me" (1 Cor 4:16). Paul's idea of imitation involves the concrete obedience of following the examples and word of Christ. This understanding led Michaelis to conclude that "mathetes and mimetes are one and the same."13

\footnotetext{
"John R. Kohlenberg, "Mimetes" The Expanded Vine's Expository Dictionary of New Testament Words (Minneapolis: Bethany House Publishers, 1984), 578.

${ }^{12}$ James Hope Moulton and George Milligan, The Vocabulary of the Greek Testament (Grand Rapids, MI: Eerdmans, 1952), 412.

${ }^{13}$ Wilhelm Michaelis, "Mimetes," Theological Dictionary of the New Testament (Grand Rapids, MI: Eerdmans, 1965), 4:673.
} 


\section{Old Testament Terms for Discipleship}

\section{Talmid}

The Old Testament is not very rich in the usage of the term disciple because, as Robert D. Meye stated, "The system of discipleship developed in the Greek world did not have a direct parallel in ancient Israel."

Karl H. Rengstorf, on the basis of his observation that there is an absence of "disciple" terminology in the Old Testament, concludes that there is a corresponding absence of the concept of discipleship as well: "If the term is missing, so, too, is that which it serves to denote. Apart from the formal relation of teacher and pupil, the OT, unlike the classical Greek world and Hellenism, has no master-disciple relation. Whether among the prophets or the scribes we seek in vain for anything corresponding to it." $" 15$

Michael J. Wilkins says that "the terms used for mathetes in the Hebrew language is talmîdh."16 Meye adds that the verb manthanein is well represented in the Septuagint ( 55 times), translating a form of the verb lamadh, which means "learn" in about thirty instances. Learning in the Old Testament generally has its specific object the command and fear of the Lord (e.g., Deut 4:10; 5:1; Ps 119:7, 71, 73; Isa 1:17; 26:9, 10). On the contrary, they are not to learn the ways of the heathen (Jer 10:2). ${ }^{17}$

${ }^{14}$ Robert P. Meye, Jesus and the Twelve (Grand Rapids, MI: Eerdmans, 1968), 94.

${ }^{15}$ Rengstorf, 4:427.

${ }^{16}$ Michael James Wilkins, "The Concept of Disciple in Mathew's Gospel" (Ph.D. dissertation, Fuller Theological Seminary, 1986), 66.

${ }^{17}$ Ibid., 94. 
According to Walter C. Kaiser, the meaning of the Hebrew word talmîdh is

scholar. He says that,

Only one OT passage, $1 \mathrm{Chr} 25: 8$, uses this word. There "the small and the great, the teacher and the scholar" are included in the selection of the twenty-four divisions of priests. In rabbinical times, the teacher of the law was called the talmîdîm Rabbi and his pupils were known as talmîdîm, i.e., apprentices. Yet in another sense, all Israel were talmidim, apprenticed to the Torah of God. The Jewish Talmud gets its name from this root. ${ }^{18}$

The Old Testament states that it is God Himself who appears as a teacher of Israel (e.g., Ps 94:10-11; Job 22:2; Deut 4:10), and the prophets were only instruments through whom God spoke, but the direct teacher of the people of Israel was God Himself.

Rengstorf continues his argument saying that since all of Israel is elect, no distinction can be made between individuals who "learn" more of God than others within the covenant community. In addition, he contends that since the "ideal" of discipleship in the Old Testament is that between Israel and Yahweh, to be the disciple of any other master would preempt the supreme place of Yahweh. ${ }^{19}$

Rengstorf's conclusion is that:

More particularly, however, the whole people are always the subject of learning. God has chosen His people in order that as a whole it may serve Him as the Lord by fulfilling His will. If the same demand is made on the individual, this is because, as a member of the chosen people of God, he has a special task, e.g., as king, and he shares the responsibility of the whole people in this specific way. ${ }^{20}$

The conclusion is that the didactic pattern in the Old Testament is different from the Greek philosophers or rabbinic schools.

\footnotetext{
${ }^{18}$ Walter C. Kaiser, "Lāmad," Theological Wordbook of the Old Testament (Chicago: Moody Press, 1980), 1:480.

${ }^{19}$ Ibid., 427-31.

${ }^{20}$ Ibid., 427.
} 
Robert Meye explains the case of Elisha and Elijah by saying,

One could point to the instance of Elisha's following of Elijah (1 Kgs 19:19ff; $2 \mathrm{Kgs}$ 2:1-15; cf also $1 \mathrm{Kgs} \mathrm{20:35;} 2 \mathrm{Kgs} 4: 38 ; 6: 1 \mathrm{ff})$ as an Old Testament pattern of discipleship. However, the pattern there is quite different form that either the Greek or rabbinic schools, and does not specifically resemble the pattern established by Jesus. For example, it is not all clear that a dominant part of Elisha's course was the reception of a teaching form Elijah-and this is clearly of great importance in the case of Jesus and his disciples. ${ }^{21}$

\section{Limmûd}

The second term for the word disciples in the Old Testament is limmûd. The adjective limmûd comes from the verb lāmad which means "learn" (qal), "teach" (piel). Kaiser finds three passages in Isaiah using this term. He says: "The taught ones in Isa 8:16 are the Lord's disciples who know his law. The servant of the Lord, however, has the tongue and ear of the learned (Isa 50:4). Therefore all Israel's children await the messianic era with joy, for all will be taught by the Lord (Isa 54:13). ${ }^{, 22}$

Wilkins says that the word limmud occurs six times in the Old Testament, always in the prophets (Isa 8:16;50:4 [2x]; 54:13; Jer 2:24; 13:23). He says that "in Jeremiah the adjective has the meaning of 'accustomed to' something, while in Isaiah it means 'taught' or 'instructed.", 23

\section{The Intertestamental Background}

In order to better understand the concept of discipleship and its implications in the

\footnotetext{
${ }^{21}$ Meye, 95 .

${ }^{22}$ Kaiser, 1:480.

${ }^{23}$ Wilkins, 67.
} 
New Testament, it is necessary to review the usage of the term during the intertestamental period.

\section{The Septuagint (LXX)}

During the intertestamental period the Greek language predominated in the ancient world so that it was necessary to translate the Hebrew books of the Old Testament. According to the tradition, seventy (or seventy-two) Jewish scholars translated the Hebrew Bible into Greek for Ptolomy II Philadelphus, between the years 285-246 BC.

Wilkins explains that the term mathetes does not occur in the accepted tradition of the Septuagint. It is found only in alternate readings of Jer 13:21, 20:11, and 26:9. He adds that "The closest approximation to the term is in $1 \mathrm{Chr} 25: 8$ where the participle 'manthanonton' translates the noun 'talmîdh.' There is no technical, student concept associated with the participle. The participle suggests that this is an apprentice; one who is engaged in learning the musical trade from a master musician." 24

\section{The Apocrypha}

Apocrypha (from the Greek word à $\pi$ ó $\rho v \varphi \alpha$, meaning "those having been hidden away") are texts of uncertain authenticity, or writings where the authorship is questioned. These books were written between c. 250-50 B.C. and do not contain examples of the use of mathetes in the Greek translation. ${ }^{25}$

The related terms found are grammateus (scribe), e.g., 1 Esdr 2:17, 25, 30; 8:3;

\footnotetext{
${ }^{24} \mathrm{Ibid} ., 140$.

${ }^{25}$ Ibid., 141.
} 
didasko (teach), e.g., Sir 9:1; 22:7; 4 Macc 5:24; 18:10; manthano (learn), e.g., Bar 3:14; Sir 30:17; and "school" Sir 51:23.

It seems that there is no Master-disciple relationship in this period of time. The emphasis is on the term "scribe." Rengstorf says that the scribal category in Sir 38:2539:11 implies a rigorous schooling in writing, making copies of the scriptures, and interpretation of scripture and oral tradition. ${ }^{26}$

\section{The Qumran Literature}

The Qumran community was developed into a cloistered brotherhood in the desert. Although the term for "disciple" is not found in Qumran literature, the structure and the organization may offer some help. Wilkins says: "The community at Qumran was a sect of Judaism which saw itself as a righteous remnant of Israel. The Teacher of Righteousness was the founder/organizer of the Qumran community (CD 1:10-11), and it developed into a cloistered, communal, brotherhood in the desert."27

The Qumran community was dedicated to studying the Torah. Allan Culpepper suggests that "there was a school at Qumran within the community and they interpreted Scripture and tradition according to the precepts of its revered Teacher of Righteousness. ${ }^{228}$ Robert P. Meye suggests that there are radical differences between the community of Qumran and the community of Jesus. As has been mentioned before,

\footnotetext{
${ }^{26}$ Rengstorf, 4: 438.

${ }^{27}$ Ibid., 144-145.

${ }^{28}$ R. Allan Culpepper, "The Johannine School; An Evaluation of the Johannine-School Hypothesis Based on an Investigation of the Nature of Ancient Schools." SBL Dissertation Series, No. 26. (Missoula,
} MT: Scholars, 1975), 170. 
Qumran cloistered itself in the desert, but Jesus moved about within Israel. ${ }^{29}$

The importance of this community is that even though there is no discipleship terminology, its structure and organization seem to be similar to the Old Testament community, where primary discipleship was given to Yahweh, but they had social structures which could be described as a master-disciple relationship.

\section{Other Disciples in the Gospels}

It is important to realize that the New Testament speaks not only about the disciples of Christ, but tells us that there were at least four other groups of disciples; the disciples of John the Baptist, the disciples of the Pharisees, the disciples of Moses, and the disciples who left Jesus.

\section{Disciples of John the Baptist}

The scriptures do not say how John the Baptist recruited his disciples. John started his ministry preaching in the desert of Judea, calling the people to repent and baptizing them in the Jordan River (Matt 3:1-11).

According to the Gospel of John (John 1:35-37), the first disciples of Jesus were John's disciples. This fact is important because John the Baptist set the basis for the discipleship of Jesus Christ.

The influence of John the Baptist on his disciples lasted after his death, because we find Apollos in Alexandria (Acts 18:24-25) and other disciples in Ephesus (Acts: 19:1-3).

Rengstorf rightly points out that, even though the relation of John to Jesus might

\footnotetext{
${ }^{29}$ Meye, 96.
} 
not have always been clear in the minds of his followers, "Men like Apollos and the disciples at Ephesus were easily able to turn to Jesus because John's way of preparation for the soon-coming Messiah remained central in the movement."30

\section{Disciples of the Pharisees}

The Bible also says that the sect of the Pharisees had disciples. Mark 2:18 mentions that the disciples of John, as well as the disciples of the Pharisees, fasted. In Matt 22:16 these disciples can be found questioning an important Pharisaic issue: paying taxes to Caesar. ${ }^{31}$

W. F. Albright and C. S. Mann say that the disciples of the Pharisees in the gospels indicate "those who were being instructed in, and who were assimilating, the teachings and practices of the Pharisees. ${ }^{, 32}$

And Wilkins points out that "all through the Gospels the Pharisees are concerned with fidelity to the Scripture, the traditions, and the unblemished practice of both. Therefore it would be expected that their mathetai were students of the law and tradition, and were practitioners of legalistic adherence to both." ${ }^{.33}$

\section{The Disciples of Moses}

The only passage where it talks about being disciples of Moses is John 9:28. The Pharisees called themselves disciples of Moses. Rather, they were claiming to be

\footnotetext{
${ }^{30}$ Rengstorf, 4:456-57.

${ }^{31}$ David Hill, The Gospel of Matthew NCB (London: Marshall, Morgan and Scott, 1972), 304.

${ }^{32}$ W. F. Albright and C.S. Mann, Matthew (Garden City, NY: Doubleday, 1971), 26, 76.

${ }^{33}$ Wilkins, 157.
} 
disciples of Moses' teachings, although they really did not follow Moses' teachings. As R. Lenski states, "The Pharisees were disciples of a fictitious Moses, whom they had invented for themselves, and who did not exist. ${ }^{34}$

\section{Early Disciples of Jesus Who Left Him}

The passage regarding these disciples who left Jesus is found only in John 6:60-66. In John 6:68 it specifically says, "From this time many of his disciples turned back and no longer followed him."

It seems that these disciples of Jesus had followed Him for some period of time, but after they heard what Jesus said, they found it too hard to accept. They did not belong to the twelve because Jesus asked them if they wanted to leave too (John 6:67).

Merrill C. Tenney, commenting on this passage says, "Those who could not understand him, or who were unwilling to trust him completely, withdrew. It was a turning point in their experience. They lacked the spiritual perception to grasp his meaning.,"35

\section{The New Testament Background The Concept of Discipleship}

Christian discipleship is a concept that was born when Jesus Christ selected His first followers. A disciple, by definition, is a convinced adherent of a school or individual. In the case of Jesus, His disciples were those who followed Him while $\mathrm{He}$ was on earth, as well as those who continue to follow Him and His teachings today.

${ }^{34}$ R. C. H. Lenski, St John's Gospel (Minneapolis, MN: Augsburg Publishing House, 1961), 696.

${ }^{35}$ Merrill C. Tenney, The Gospel of John, The Expositor's Bible Commentary, vol. 9 (Grand Rapids, MI: Zondervan, 1981), 79. 
Christian discipleship began, according to John's gospel, the day after Jesus was baptized (John 1:35-39). According to this passage, the first two men to follow Him heard John the Baptist declare that Jesus was the Lamb of God. Andrew and his friend (most likely John) believed what they heard and followed Jesus. Before long, they were telling others about this amazing Man of God.

Andrew recruited his brother Simon (whom Jesus called Peter); the next day Jesus found Philip in Galilee; Philip found Nathaniel and soon a movement was born.

\section{The Twelve}

The New Testament records the list of the names of the twelve disciples of Christ four times (Matt 10:2-4, Mark 3:13-19; Luke 6:12-16; Acts 1:13). Even though there are certain differences regarding the order of the list, the twelve names are the same. The only difference is that after the ascension of Christ, Luke records only eleven, due to the fate of Judas Iscariot. Jesus does not indicate why He determined the number of disciples should be twelve, but it may be because of the twelve tribes of Israel. The number twelve was considered important enough that between the ascension of Jesus and Pentecost, the Church replaced Judas with a new apostle. The eleven disciples chose Mathias to replace Judas (Acts 1:20,21). The new disciple had to be a witness of the life and resurrection of Jesus.

The twelve had a great relevance for Jesus, perhaps because Jesus wanted to have a closer relationship with them. Michael Wilkins says,

The four Gospels witness unanimously to a core of twelve disciples who were called by Jesus into a special relationship with him. Jesus chose twelve out from among a much larger number of disciples. These Twelve became his constant companions. They joined with him in proclamation of the kingdom message and were training to become apostles of the future church (cf. Luke 6:13,17). These twelve disciples 
were so prominent in Jesus' ministry that at many points in the gospel record the word disciple is synonymous with the Twelve. ${ }^{36}$

The Disciples of Jesus

The New Testament presents several aspects related to Jesus' process of making disciples.

First, the call of the disciples of Jesus:

1. The Initiative of Jesus. A fundamental mark of the $\mu \alpha \theta \eta \tau \alpha i$ of Jesus is that they were called by Him to discipleship. This aspect dominates all the accounts of the way in which they began to follow Jesus. Passages like Mark 5:18ff, Luke 9:57ff and Luke 5:1ff attest that the call was an initiative of Jesus.

2. Some Disciples Were Not Personally Called. There were some other disciples who were not called directly by Jesus. Among them were a large number of common people (Luke 6:13), a variety of men and women who supported Jesus' ministry and accompanied Him from Galilee (Matt 8:21; Mark 15:41; Luke 8:2-3; 23:49, 55; 24:13, 18, 33). Also there were tax collectors (Zacchaeus, Luke 19:1-10), scribes (Matt 13:52), and religious leaders (Nicodemus and Joseph of Arimathea, John 19:38-42).

Second, the disciples of Jesus in their relation to Him:

1. The Commitment of the Disciples to Jesus. The relation between Jesus and His disciples was unique. It was a personal relationship from Jesus to them and vice versa. Rengstorf suggests that "the allegiance of the disciples to Jesus is confirmed by their conduct in the days between the crucifixion and the resurrection",37

\footnotetext{
${ }^{36}$ Michael J. Wilkins, Following the Master: Discipleship in the Steps of Jesus (Grand Rapids, MI: Zondervan Publishing House, 1992), 125, 126.

${ }^{37}$ Rengstorf, 4:446.
} 
2. The Obedience of the Disciples to Jesus. Matt 10:37 suggests that a disciple of Jesus should be able to renounce all that is indispensable for the sake of following Jesus.

3. The Obligation of the Disciples to Suffer for Jesus. Jesus explained to the disciples that they would have to suffer for the kingdom of heaven. That was the price they had to pay. In Matt 10:21-23 it says,

And brother will give up brother to death and the father his child: and children will go against their fathers and mothers, and put them to death. And you will be hated by all men because of my name: but he who is strong to the end will have salvation. But when they are cruel to you in one town, go in flight to another: for truly, I say to you, you will not have gone through the towns of Israel before the Son of man comes.

\section{Jesus' Method of Making Disciples}

Men Were His Method

The method that Jesus used to make disciples differs substantially from the other teachers like Jewish rabbis and Greek philosophers. Jesus focused on the person not on the results. His goal was to change lives and have a personal relationship with His disciples. Jesus made disciples by calling them to be with Him. David Watson, in his book Called and Committed: World Changing Discipleship says that it was a call "to be with him and commit themselves wholeheartedly to him., ${ }^{38}$

Jesus started calling a few men to follow Him. Coleman says, "This revealed immediately the direction His evangelistic strategy would take. His concern was not with programs to reach the multitudes but with men whom the multitudes would follow." 39

Jesus' method was first to win the heart of His disciples even before He started

\footnotetext{
${ }^{38}$ Watson, 2-3.

${ }^{39}$ Coleman, 39.
} 
preaching. Coleman suggests: "Remarkable as it may seem, Jesus started to gather these men before He ever organized an evangelistic campaign or even preached a sermon in public. Men were to be His method of winning the world to God." ${ }^{40}$

The initial objective of Jesus' plan was to enlist those who could bear witness to His life and carry on His work after He returned to His Father.

\section{Jesus' Strategy in Recruiting Disciples}

First, Jesus looked for men willing to learn. The strategy that Jesus used to recruit His disciples astonished the minds of most people. He did not choose His disciples from the high classes of the society, from the political leaders, or from the religious hierarchy. He chose them from the common class of people.

Concerning the class of people Jesus chose, Coleman says,

What is more revealing about these men is that at first they do not impress us as being key men. None of them occupied prominent places in the synagogue, nor did any of them belong to the Levitical priesthood. For the most part they were common laboring men; probably having no professional training beyond the rudiments of knowledge necessary for their vocation ... They had no academic degrees in the arts and philosophies of their days. ${ }^{41}$

William Barclay adds, "The disciples were very simple people. They did not come from the schools or universities, neither from the ecclesiastic class and the aristocracy." 42

The disciples, in addition to being common people and not having the qualities according to the standards of society, had something that Jesus was looking for. They

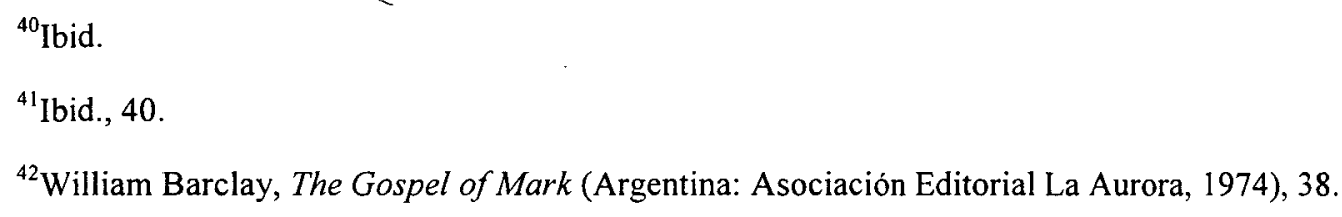


were willing to learn. Coleman points out, "Jesus saw in the simple men the potential of leadership for the kingdom. They were indeed 'unlearned and ignorant' according to the world's standard (Acts 4:13), but they were teachable." ${ }^{43}$

The second strategy used by Jesus in choosing His disciples was to call a small group. He concentrated on a few people. The question is why? Coleman answers: "The answer to this question focuses at once on the real purpose of his plan for evangelism. Jesus was not trying to impress the crowd, but to usher in the kingdom. This meant that He needed men who could lead the multitudes. ${ }^{\circ 4}$

\section{Jesus' Training Strategy}

Jesus spent most of His earthly ministry training His disciples. His concern was to teach them the work they would have to do after He left this earth. In Matthew chapter 10 is the outline that Jesus used in training His disciples. First, Jesus gave them power over unclean spirits to cast them out. Second, He gave them the power to heal every kind of disease and sickness. After Jesus empowered them, He gave them several instructions that we can summarize as follows:

1. The disciples should preach first to the lost sheep of the house of Israel (v v. 5-6).

2. The message was specific: "The kingdom of heaven is at hand" (v. 7).

3. Heal the sick, raise the dead, cleanse the lepers and cast out demons (v. 8).

${ }^{43}$ Coleman, 41 .

${ }^{44}$ Ibid., 47. 
4. The disciples were not to be worried about material things, because the worker is worthy of his support ( $\mathrm{v}$ v. 9-10).

5. Jesus taught the disciples how to interact with people in the cities, villages, and houses (v v. 11-15)

6. The disciples had to be wise as serpents and innocent as doves, since they were sent out as sheep in the midst of wolves (v. 16).

7. The disciples would be delivered before governors and kings, but they did not have to worry because the Holy Spirit would speak through them (v v. 17-20).

8. Finally, Jesus told them that they would be persecuted for His sake, but those who endured to the end would be saved (v. 22).

Ellen G. White explains the method Jesus used to train His disciples very well when she said:

For three years and a half the disciples were under the instruction of the greatest Teacher the world has ever known. By personal contact and association, Christ trained them for His service. Day by day they walked and talked with Him, hearing His words of cheer to the weary and heavy-laden, and seeing the manifestation of His power in behalf of the sick and the afflicted. Sometimes He taught them, sitting among them on the mountainside; sometimes beside the sea or walking by the way, He revealed the mysteries of the kingdom of God. Wherever hearts were open to receive the divine message, He unfolded the truths of the way of salvation. He did not command the disciples to do this or that, but said, "Follow Me." On His journeys through country and cities, He took them with Him, that they might see how He taught the people. They traveled with Him from place to place. They shared His frugal fare, and like Him were sometimes hungry and often weary. On the crowded streets, by the lakeside, in the lonely desert, they were with Him. They saw Him in every phase of life. ${ }^{45}$

\footnotetext{
${ }^{45}$ Ellen G. White, The Acts of the Apostles (Hagerstown, MD: Review and Herald, 1911), 18, 19.
} 


\section{The Concept of Discipleship in Ellen G. White Writings}

Ellen G. White does not expand too much on the concept of discipleship. What she does is mention several characteristics of disciples, which will be discussed in chapter three. However, she states that with the calling of the disciples, Jesus set the foundation of the Christian Church.

With the calling of John and Andrew and Simon, of Philip and Nathaniel, began the foundation of the Christian church. John directed two of his disciples to Christ. Then one of these, Andrew, found his brother, and called him to the Savior. Philip was then called, and he went in search of Nathaniel. These examples should teach us the importance of personal effort, of making direct appeals to our kindred, friends, and neighbors. There are those who for a lifetime have professed to be acquainted with Christ, yet who have never made a personal effort to bring even one soul to the Savior. They leave all the work for the minister. He may be well qualified for his calling, but he cannot do that which God has left for the members of the church. ${ }^{46}$

Another principle we find in Ellen G. White's writings is that every true disciple is born into the kingdom of heaven as a missionary. White states that "every true disciple is born into the kingdom of God as a missionary. He who drinks of the living water becomes a fountain of life. The receiver becomes a giver. The grace of Christ in the soul is like a spring in the desert, welling up to refresh all, and making those who are ready to perish eager to drink of the water of life." ${ }^{, 47}$

True discipleship, according to the thinking of Ellen G. White, is the mission of the church. There is no other duty more important for the church than those involved in soul winning. It is expected that every new believer, if indeed he/she has been born again, feels the joy and the responsibility of working for his Master. Ellen G. White says there is a rich reward for those who are willing to work in soul winning. She comments,

\footnotetext{
${ }^{46}$ Ellen G. White, Desire of Ages (Hagerstown, MD: Review and Herald, 1898), 141.

${ }^{47}$ Ibid., 195.
} 
"A rich reward will be given to the true workers, who put all there is of them into the work. There is no greater bliss on this side of heaven than in winning souls to Christ. Joy fills the heart as the workers realize that this great miracle could never have been wrought by human agencies, but only through the One who loves souls ready to perish. ${ }^{48}$

\section{Understanding the Great Commission}

The Great Commission was given by Jesus to His disciples before He departed to His Father's kingdom. Matthew says, "Go ye therefore, and make disciples of all the nations, baptizing them into the name of the Father and of the Son and of the Holy Spirit: teaching them to observe all things whatsoever I commanded you: and lo, I am with you always, even unto the end of the world (Matt 28:19-20)."

In order to understand this passage, it is necessary to have a basic understanding of the grammatical structure of the sentences. Jesus' command is in the form of an imperative in the main verb "make disciples," which is surrounded by three participles (go, baptize, teach), which describe what must be done to fulfill the command.

A disciple is a learner or a pupil. Jesus' call to discipleship is recorded as early as Matt 11:29, when He said, "Take my yoke upon you and learn from Me." To be a learner is to be a disciple. Thus, Jesus' command was for the disciples to enroll others in His school, assisting others in becoming learners about Christ. Gary L. McIntosh says, "This word for making disciples is an exceptional word that is used only four times in the New Testament and only in the Great Commission as a command. The word disciple implies not only acquiring knowledge but living out what one learns. To be a disciple is to be

\footnotetext{
${ }^{48}$ Ellen G. White, Evangelism (Hagerstown, MD: Review and Herald, 1973), 333.
} 
committed adherent who is personally involved in carrying out the will of the master."49

The Greek word for to make disciples, matheteuo, is found only four times in the New Testament, three times in Matthew (13:52; 27:57; 28:19), and once in Acts $(14: 21)$. The form of the verb in the Great Commission passage is in imperative aorist accusative second person plural.

The mandate to make disciples in the Great Commission is accompanied by three other verbs in the form of participles. The first participle, "going," describes action that is concurrent with the imperative verb "make disciples." This participle picks up the force of the mandate and is thus correctly translated as an imperative "go." Without the action of "going," it is impossible to make disciples. This word makes the mandate explicit and intentional. It is not, "If you happen to be going," but "Go!" which indicates a sense of urgency. Followers of Christ are to take the initiative in making disciples of all nations. We are not to wait casually for some accidental contact, but we are to go. It is logical to think that "going" must take place before a disciple can be made; thus it presupposes the idea of winning others to Christ or evangelizing. It also implies that believers are to spend time with unbelievers building personal relationships with them.

The other two participles are "baptizing" and "teaching." These participles describe the means by which disciples are made. Each time a person is won to Christ through going, he or she is to be baptized and taught. The two participles "baptizing" and "teaching" are in the present tense, which indicates that the act of baptizing the new converts is a continual event, and teaching them is to be an ongoing process. Baptizing implies the attachment of new believers to Christ and His church, while teaching implies

${ }^{49}$ Gary L. McIntosh, Biblical Church Growth (Grand Rapids, MI: Baker Books, 2003 ), 65. 
the continual maturation of the believers as they are taught all things. Thus, Christ commands us to assist people to become disciples by taking the initiative in sharing the gospel with the unsaved by going and then helping them to be attached to Him and His church through baptism, and helping them to mature through the teaching process.

The Great Commission given to the disciples was to be carried to all nations. The extent of His command is universal. The Greek word for "all nations" is panta ta ethne. The word ethne is translated "nations" but should not be understood as a political nation, such as Mexico, France, or China. The basic meaning of this word is tribe, people, family, or ethnic group. This means that the command is extensive and inclusive. No one has to be put aside. Every creature in the world has to have the opportunity to listen and accept the gospel. It is their responsibility to accept or reject it.

The Great Commission ends with a promise given by the Lord Jesus. This promise is very important for several reasons. First, it tells us that the Great Commission is for us today. Jesus said that His commission to make disciples would be an ongoing process until His kingdom would be established. It would be a permanent process. Second, Jesus promised to be with His disciples until the end of the age. It is obvious that the disciples died in the first century, but the promise of His presence is for those who followed Him through the ages until the end of the world.

McIntosh explains that "biblical church growth views discipleship as the process of finding and winning the lost, folding them into a local church, and building them up in the faith." 50

This process comes directly from Jesus' command to make disciples. This

$$
{ }^{50} \text { Ibid., } 68 .
$$


process is clear when we apply the three participles that come with the imperative verb "to make disciples."

The first step in the process of making disciples is finding and winning the lost. The first participle in the process is "going." This participle takes the force of the imperative verb "to make disciples" and comes before the command. Logically, if we do not go, we will not find the lost and be able to make them disciples. The Bible tells us that the special mission of Jesus was to seek and save the lost (Luke 19:10). Jesus' earthly ministry, starting with His virgin birth until His death, resurrection, intercession, and glorious return is attached to God's desire to save souls. Arthur Glasser comments on this: "The crucifixion and resurrection of our Lord are inherent to the record of the gospel of Jesus Christ. And yet, the events surrounding his cross and empty tomb do not climax the gospel narratives. The climax is his issuance of the mandate to disciple the nations. This mandate is to be obeyed. Jesus Christ expects us to give ourselves to the task of gathering the lost." 51

To save the lost, the church has to give evangelism first priority in the process of making disciples. Ellen G. White states that evangelism should be the "real work." She says, "Evangelistic work, opening the Scriptures to others, warning men and women of what is coming upon the world, is to occupy more and still more of the time of God's servants. $" 52$

The second step in the process of making disciples, according to the Great Commission, is the participle "baptizing." Without "going" and seeking for the lost and

\footnotetext{
${ }^{51}$ Harvie Conn, ed., Theological Perspectives on Church Growth (Phillipsburg, New Jersey: Presbyterian and Reformed Publishing, 1977), 31.

${ }^{52}$ White, Evangelism, 17.
} 
preaching the gospel to them, there are no decisions made for Christ. Baptism is a commitment to be bond first to Christ and then to His church. The apostle Paul explains very well the meaning of baptism in Rom 6:3-7:

Do you know that all of us who have been baptized into Christ Jesus have been baptized into his death? Therefore we have been buried with Him through baptism into death, so that as Christ was raise from the dead through the glory of the Father, so we too might walk in newness of life. For if we have become united with Him in the likeness of His death, certainly we also be in the likeness of His resurrection, knowing this, that our old self as crucified with Him, in order that our body of sin might be done away with, so that we would no longer be slaves to sin for he who has died is freed from sin.

The new believers are identified with Jesus in His death and resurrection. This new identity becomes the basis for their new life. But the new believers are also identified with the church, the body of all believers. It is interesting that through baptism the new believer is united to the church.

The writer of the Acts of the Apostles said that when Peter preached his sermon at Pentecost, about three thousand people were baptized and added to the church (Acts 2:41). Thus, when the new believer is baptized, he or she is connected with Jesus Christ and also to the church.

The third step in the process of making disciples is "teaching." This is the third participle that completes the process of making disciples. The purpose of this step is to keep the new believers in the church. We could call this step the process of growing or the process of sanctification. It is a lifelong process. E. G. White comments on this:

Sanctification is not the work of a moment, an hour, a day, but of a lifetime. It is not gained by a happy flight of feeling, but is the result of constantly dying to sin, and constantly living for Christ. Wrongs cannot be righted nor reformations wrought in the character by feeble, intermittent efforts. It is only by long, persevering effort, sore discipline, and stern conflict that we shall overcome. We know not one day how strong will be our conflict the next. So long as Satan reigns, we shall have self to subdue, besetting sins to overcome; so long as life shall last, there will be no stopping 
place, no point which we can reach and say, I have fully attained. Sanctification is the result of lifelong obedience. ${ }^{53}$

The principle of teaching in the process of making disciples is vital. Teaching is the process of transferring knowledge through a personal experience. In the Great Commission Jesus said, "Teaching them to observe all that I commanded you: and lo, I am with you always, even unto the end of the world. Amen" (Matt 28:20).

The apostle Paul commends the following to his disciple Timothy: "Prescribe and teach these things. Pay close attention to yourself and to your teaching; persevere in these things; for as you do this you will insure salvation both yourself and for those who hear you" (1 Tim 4:11, 16).

To understand the Great Commission, it is important to have a wide understanding of Jesus' command about the process of making disciples. McIntosh summarizes this process:

Discipleship is a process that involves all three of these elements - going, baptizing, and teaching. If a church focuses on only one of the three, it will have difficulty seeing biblical church growth take place. Some churches do a fine job of winning people to Christ; however, because they do little in the way of assimilation, they end up with few people to teach. Other churches focus on the teaching of believers but find few new converts coming into their fellowship to be taught. Still others stress a warm welcome but find people leaving after awhile due to the shallow teaching. Churches that experience solid biblical church growth will have a process that gives balanced emphasis to all three of these areas. ${ }^{54}$

\section{Conclusion}

We are living at the end of time. Jesus' last commandment was and still is "Go and make disciples of all nations ..." (Matt 28:19). If the gospel has to be spread to the

\footnotetext{
${ }^{53}$ White, The Acts of the Apostles, 560, 561.

${ }^{54}$ McIntosh, 73.
} 
entire world, there is only one way to do it: follow Jesus' order.

Moorehead says,

Mission is not optional. It is what the church is all about. What we call the Great Commission has too often been the Great Omission. Yet, Jesus declared that mission is why the church exists. That's why the Great Commission appears five times in the New Testament (Matt 28:18-20; Mark 16:15, 16; Luke 24:47; John 20:21; Acts 1:8). What oxygen is to fire, mission is to the church. As fire exists by burning, so the Church exists by mission. ${ }^{55}$

To make disciples was Jesus' objective because He knew that is the way to reach the unreached. But to be a disciple is not only to be a follower of Jesus, it is to integrate Jesus in our daily lives.

Joana Dewey says, "Discipleship is not a list of ways in which we should behave; rather, it is a way of life, in which one part is not separate from another." ${ }^{.56}$

${ }^{55}$ Moorehead, 104.

${ }^{56}$ Joana Dewey, Mark on Discipleship (Cincinnati, OH: Education and Cultivation Division, 1976), 50. 


\section{CHAPTER 3}

\section{CHARACTERISTICS OF A DISCIPLE}

To be a disciple is to be more than a follower of Christ. There is a big difference between a true disciple of Christ and a simple follower. In this chapter, we are going to study the characteristics of a true disciple. Bill Hull says, "Jesus ordered us to 'make disciples.' Disciples are both the people who please the Lord and the people who will reach the world. Therefore, a clear identification of a disciple is imperative.

Understanding what a disciple is and what a disciple does are top priority for the church.",

\section{Jesus' Insight of a Disciple}

Since Jesus was the disciple-maker par excellence, His description of disciple is the most important factor in defining a disciple. Christ was speaking to the disciples when He gave the Great Commission to the church. He said, "Make disciples." Jesus suggested seven basic essentials for becoming a disciple:

1. The disciple makes Jesus preeminent in his life (Luke 14:26-33).

2. The disciple has to remain in the Word of God (John 8:31).

3. The disciple is willing to deny himself, take up a cross daily, and follow Him (Luke 9:23).

${ }^{1}$ Hull, 54. 
4. The disciple is a reproduction of his Master (Matt 10:24, 25).

5. The disciple loves others as Christ loves them (John 13:34, 35).

6. The disciple is obedient to the Lord's commandments (John 14:15).

7. The disciple makes others disciples (Matt 28:19, 20; John 15:8).

\section{Brief Discussion of Jesus' Insight of a Disciple}

1. The disciple makes Jesus preeminent in his life (Luke 14:26-33).

The life of the disciple is permeated by the life of Jesus. Nothing else can take the place of Jesus. According to Luke 14:26-33 Jesus Christ has to be above the family, above the disciple's own life, and above all possessions. Ellen G. White said, "Christ in the heart, Christ in the life, this is our safety. The atmosphere of His presence will fill the soul with abhorrence of all that is evil. Our spirit may be so identified with His that in thought and aim we shall be one with Him.".2

2. The disciple has to remain in the Word of God (John 8:31).

The Word of God is food for the soul. As Stormie Omartian wrote, "God's Word is food for our souls. We cannot live without it. It is written that 'man shall not live by bread alone, but by every word that precedes from the mouth of God' (Matt 4:4). If we are not continually fed with God's Word, we will starve spiritually."3 The disciple of Jesus needs to study the Word of God on a daily basis. Jesus was very emphatic when He said, "If you remain in my word, then you are truly my disciples" (John 8:31). The Greek word for remaining is meno and is also found in the context of abiding in John 15.

\footnotetext{
46.

${ }^{2}$ Ellen G. White, Colporteur Ministry and Help in Daily Living (Nampa, ID: Pacific Press, 1990),

${ }^{3}$ Stormie Omartian, The Power of a Praying Woman (Eugene, OR: Harvest House Publishers, 2002), 87.
} 
In this chapter, the evangelist develops the abiding concept by the use of the metaphor of the vine and branches and teases out the intimate and binding covenant relationship between Jesus and His disciples. Jesus is presented as the True Vine and the Father as the Vinedresser who cares for the well-being of the vine and the branches (vv. 1-2). Jesus' disciples are represented as the fruitful branches that are made clean by Jesus' word. The disciples can only abide in Jesus through His word, in order to be clean and bring fruits which are the result of being attached to the True Vine, Jesus Christ. Rekha M. Chennattu underlined the importance of the concept of abiding in Christ. He says, The mutual and binding covenant relationship between Jesus and His disciples is underlined. The community of the disciples designated in the metaphor as the fruitful branches (vv. 3-5) abiding in Jesus, the True Vine, becomes the new vineyard of Yahweh. The Johannine community is told that they are called to remain faithful to Yahweh by abiding in Jesus, the True Vine. Abiding is, therefore, an imperative for the disciples, and it is an evocative and powerful metaphor of communion shared among the disciples in the community. ${ }^{4}$

3. The disciple should deny himself, taking his cross daily (Luke 9:23-25).

The center of a disciple's life is not himself. The center is Jesus Christ. The apostle Paul declares this emphatically when he said, "I have been crucified with Christ; and it is no longer I who live, but Christ lives in me; and the life which I now live in the flesh I live by faith in the Son of God, who loved me, and delivered Himself up for me" (Gal 2:20). The apostle Paul declares further, "But may it never be that I should boast, except in the cross of our Lord Jesus Christ, through which the world has been crucified to me, and I to the world" (Gal 6:14). Henry Blackaby, commenting on this verse, says, "The cross shows us how to die to the world's hold upon us, and it opens up our

${ }^{4}$ Rekha M. Chennattu, Johannine Discipleship as a Covenant Relationship (Peabody, MA: Hendrickson Publishers, 2006), 114, 115. 
understanding for walking the path of discipleship, for a life-time of following our Savior and shepherd." The cross was the ultimate price Christ paid for our sins, that is why it is very important for the disciple to understand it. Blackaby adds that "without the cross, there is no discipleship."

4. The disciple is a reproduction of his Master (Matt 10:24, 25).

Jesus said, "The disciple is not above his master, nor the servant above his lord. It is enough for the disciple that he be as his master, and the servant as his lord. If they have called the master of the house Beelzebub, how much more shall they call them of his household?" (Matt 10:24,25). Even though this passage is talking about persecution, in the sense that, as Christ was persecuted (Matt 10:28), the disciple will have to endure that same hardship. Jesus said, "It is enough for the disciple that may be as his master." Here Jesus established a discipleship principle that the disciple has to be a reproduction of his master. The disciple has to reproduce in himself the character of his master; in other words, the disciple has to be like Jesus.

Daniel Patte, in his book The Challenge of Discipleship, A Critical Study of the Sermon on the Mount as Scripture, comments that:

Before the advent of the kingdom, no one, except Christ, can display all the kinds of behavior described in the beatitudes. Thus, discipleship remains an 'imitation of Christ' (imitatio Christi), even if there are other people who are partial models of discipleship despite their imperfections.

Imitating the one who embodies the beatitudes (Christ and, secondarily, other models) does not mean acting exactly as Christ does (his behavior is not a norm to be implemented...). It means being both like him and unlike him.

${ }^{5}$ Henry Blackaby, Experience the Cross (Sisters, OR: Multnomah Publishers, 2005), 156.

${ }^{6}$ Ibid. 
Disciples should follow Jesus (thus, continuity), but at some distance-following implies being behind (thus, some discontinuity). ${ }^{\text {? }}$

To be an imitator of Jesus is a big challenge. From the human perspective, it is impossible for men to become like Jesus. This is a work of the Holy Spirit. The Holy Spirit is the One who works inside the human heart in order to change the sinful nature. When the Holy Spirit has transformed our hearts and we have accepted the Lordship of Jesus, then we can say as the apostle Paul said, "Be imitators of me, just as I also am of Christ" (1 Cor 10:1).

Jesus declared emphatically that to be a disciple is to become like the master.

Luke 6:40 says, "The disciple is not above his master: but every one that is perfect shall be as his master." But, what does it mean to become like Jesus? Michael J. Wilkins explains,

Becoming like Jesus includes going out with the same message, ministry, and compassion (Matt 10:5ff.); practicing the same religious and social traditions (Matt 12:1-8; Mark 2:18-22); belonging to the same family of obedience (Matt 12:46-50); exercising the same servanthood (Mark 10:42-45; Matt 20:26-28; John 13:12-17); and experiencing the same suffering (Matt 10:16-25; Mark 10:38-39). The true disciple was to know Jesus well, was to have followed him so closely, that he or she would become like him. The ultimate goal was to be conformed to his image (cf Luke 6:40; Rom 8:28, 29)."

5. The disciple loves others as Christ loves them (John 13:34-35).

One of the essential ingredients in discipleship is love. First, love to God and love to people. The apostle Paul wrote to the Corinthian church:

If I speak with the tongues of men and of angels, but have not love, I am become sounding brass, or a clanging cymbal. And if I have [the gift of] prophecy, and know all mysteries and all knowledge; and if I have all faith, so as to remove mountains, but

\footnotetext{
${ }^{7}$ Daniel Patte, The Challenge of Discipleship: A Critical Study of the Sermon the Mount as Scripture (Harrisburg, PA: Trinity Press International, 1999), 90.

${ }^{8}$ Wilkins, Following the Master, 357.
} 
have not love, I am nothing. And if I bestow all my goods to feed [the poor], and if I give my body to be burned, but have not love, it profited me nothing (1 Cor 13:1-3).

Love is the foundation of discipleship. Without love it is impossible to be a disciple. Russell Burrill comments,

Love is to be the absolute, infallible test of one's discipleship. You can tell that a person is a disciple when that person loves as Jesus does-unconditionally. It does not mean that love is fully perfected, but the agape love of Jesus should be found, at least embryonically, in the life of the one who is a disciple. Again, Jesus is giving us tests of discipleship. If the Great Commission commands us to make disciples, then to produce people whom we call Christians but who do not have the love of Christ abiding in their hearts, is to misrepresent the gospel of Christ. ${ }^{9}$

The key mark of discipleship is love. Jesus said, "By this shall all men know that ye are my disciples, if ye have love one to another" (John 13:35). The context of this passage is the foot-washing episode. This principle of the love is intrinsically related to service. Melvyn R. Hillmer says,

Following Jesus and showing love for one another are directly related to service, as is dramatically portrayed in the episode of Jesus washing His disciples' feet. The relationship of the disciples with Jesus is one in which He calls them His friends. But this does not negate his call to service. Rather, it heightens it. The disciples call Him Teacher and Lord, and correctly so (John 13:13). It is in these roles that He washes their feet and in this context of service that He calls them friends. ${ }^{10}$

Love and service are sisters. They belong together. Jesus asked Peter three times if he loved Him. For each time Peter confesses his love for Jesus, he is called to service. Jesus said to him three times "Feed my sheep." Love for Jesus and service to the people, therefore, are interwoven.

6. The disciple is obedient to the Lord's commandments (John 14:15).

\footnotetext{
${ }^{9}$ Russell Burrill, Radical Disciples in a Revolutionary Church (Fallbrook, CA: Hart Research Center, 1996), 36.
}

${ }^{10}$ Melvyn R. Hillmer, "They Believed in Him: Discipleship in the Johannine Tradition," in Patterns of Discipleship in the New Testament, ed. Richard N. Longenecker (Grand Rapids, MI: Eerdmans, 1996), 91. 
Another characteristic of discipleship is obedience. Obedience is the fruit of love. Jesus requires loving obedience of His disciples. He taught that love equals obedience, that the very act of obedience is love. That is the reason Jesus said, "If you love me, keep my commandments" (John 14:15). The context of this passage is when Jesus was talking with His disciples in the upper room the night He took the Passover with them. Hillmer comments, "Discipleship involves keeping the word or words of Jesus and keeping his commandments. And keeping his words and commandments is also directly connected with one's love for Jesus." 11

The obedience factor is one of the elements included in the Great Commission, "Teaching them to obey everything I have commanded you" (Matt 28:20). The book of Revelation portrays an obedient church in the last days. In the context of the Three Angels' Messages, John says, "Here is the patience of the saints, they that keep the commandments of God and the faith of Jesus" (Rev 14:12). The Adventist Church has claimed to be the remnant church according to Rev 12:17: "And the dragon waxed wroth with the woman, and went away to make war with the rest of her seed that keep the commandments of God, and hold the testimony of Jesus."

As a remnant church that claims to keep the commandments of Jesus, the church also has to obey the commandment included in the Great Commission to make disciples. The Three Angels' Messages are connected with the Great Commission. The Three Angels' Messages are the base for our mission, as Russell Burrill states:

Adventism, then, must see as the basis of its mission this passage in Revelation 14:612. Yet the Three Angels' Messages can be properly understood only against the background of the Great Commission. Revelation 14 must be seen as an extension of John's commentary on the Great Commission as it is to be carried out in the last days

\footnotetext{
${ }^{11}$ Ibid.
} 
of human[ity] to the goal of the Great Commission - the making of disciples who keep the commandments of God and remain faithful to Jesus. Such a people are spiritually developed, mature Christian disciples who are, in the fullest sense, ready to meet Jesus when He returns. ${ }^{12}$

So, the function of the Adventist Church is to make disciples that can produce other disciples in order that they can be ready to meet Jesus at His second coming. This task is urgent, considering the promptness of Jesus' return.

7. The disciple makes others disciples (Matt 28:19; John 15:8).

The task of making disciples is vital in discipleship. This is the special command of Jesus before He was taken to heaven (Matt 28:19). If the disciples had not accomplished this commandment, the gospel would not have gone to the whole world. Moreover, it is the only way to finish the preaching of the gospel. This is the law of reproduction. That was the case of Andrew who, after recognizing the Lord Jesus as the Messiah, brought his brother, Simon, whom Jesus called Peter. Likewise, Phillip after being called by Jesus, went to his friend Nathanael and invited him to come to see the Messiah (John 1:40-45).

One test of discipleship is bearing fruit. In John chapter 15:1-8 we find the parable of the True Vine. Jesus is represented as the True Vine and the Father as the Vinedresser who cares for the well-being of the vine and its branches, the disciples. The disciples must abide in Christ in order to bear fruit (v. 5). As a result of abiding in Christ, the branches (the disciples) will produce abundant fruit and, consequently, the Father will be glorified and they will show that they are indeed Jesus' disciples. What is this fruit? Some commentators suggest that Jesus was thinking of the fruits of the Spirit enunciated

\footnotetext{
${ }^{12}$ Burrill, 81.
} 
by the apostle Paul in the book of Galatians. ${ }^{13}$ The context of this passage is that Jesus is referring to Himself as the true vine and the disciples as the branches. The work of the branches is to produce because of the living connection to the Vine. Otherwise, the branches are cut off and burned in the fire. The context of this passage appears to be related to the mission of making disciples. Russell Burrill, commenting on this, says,

The whole context of this passage seems to center on a mission understanding. The Christian who is not reproducing by creating other disciples is not really disciple. It is impossible, then, to be a follower of Jesus and not share Him. Disciples must not only share, they must also make disciples; otherwise, they cannot be considered disciples. Jesus' discipleship invites people into a lifetime of disciples making. Jesus wants us to produce much fruit; this is not to be a casual convert once in lifetime. ${ }^{14}$

Inherent in the call to be a disciple of Jesus is the call to be a fruit-bearing Christian. In this sense, Jesus Christ declares that Christian discipleship cannot exist unless those who are following Him are involved in the process of making disciples. This concept is implied in the Great Commission, where Jesus demands that His followers go and make disciples.

Kent R. Hunter says that "every Christian should grow up to the maturity of discipleship and then reproduce other disciples. Every disciple should be a spiritual parent for other growing disciples, then a grandparent, then a great grandparent."

The early church followed the order of Jesus. The book of Acts registers that the disciples were actively teaching and preaching every day. "And every day, in the temple and at home, they ceased not to teach and to preach Jesus as the Christ" (Acts 5:42). As a

${ }^{13}$ Hull, 69.

${ }^{14}$ Burrill, 37.

${ }^{15}$ Kent R. Hunter, Foundations for Church Growth: Biblical Basics for the Local Church (Corunna, IN: Church Growth Center, 1994), 85. 
result, Luke registers that the numbers of disciples increased in a marvelous way (Acts $6: 1,7)$

Even though the Greek word for disciple does not appear in the epistles and the book of Revelation, ${ }^{16}$ the concept of reproducing disciples is implied.

The apostle Paul followed this pattern of discipleship with his spiritual son, Timothy, "So then, my child, be strong in the grace which is in Christ Jesus. And the things which I have said to you before a number of witnesses, give to those of the faith, so that they may be teachers of others" (2 Tim 2:1-2).

What Paul was doing with Timothy was being a model in discipleship. Timothy had to imitate the life of his teacher, but also had to share his faith with others. Not only that, Timothy had to train others to be teachers of others as well. We can see that the chain of discipleship has continued until our time. We can understand this chain of discipleship when we go back to the Great Commission (Matt 28:19-20), because there is a promise made by Jesus, that He will be with the disciples, who were making more disciples, until the end of the world. The promise of His presence in His church will not only be in terms of protection, as many have considered it, but was to ensure His disciples that the process of making disciples would succeed.

\section{Marks of a Disciple}

Michael W. Foss, pastor of Prince of Peace, a congregation of the Evangelical Lutheran Church in America in Burnsville, Minnesota, presents six simple marks of discipleship in his book. This list is not in any particular hierarchical order.

\footnotetext{
${ }^{16}$ Wilkins, "The Concept of Disciple in Matthew's Gospel," 283.
} 


\section{The First Mark of a Disciple: Daily Prayer}

It seems that all Christian believers should know how to pray. But this is not true. We sometimes think we know how to pray, but even Jesus' disciples asked Him to teach them about prayer: Michael W. Foss adds, "This problem of not knowing how to pray is not a new one. Some two thousand years ago Jesus was praying in a certain place, and after he had finished, one of his disciples said to him. 'Lord teach us to pray' (Luke 11:1). Prayer can be taught and learned." 17

The disciple of Jesus should not only pray himself, but he has to understand that Jesus is praying on his behalf. Ellen G. White wrote: "For hours He continued pleading with God. Not for Himself but for men were those prayers. . . In travail and conflict of soul He prayed for His disciples ... For them, the burden was heavy upon His heart, and He poured out His supplications with bitter agony and tears." 18

Philip Samaan, in his book Christ's Way to Pray, states: "Jesus prayed not only for His disciples but also for all others who would believe in Him (John 17:6-26). His earnest prayer was saturated with love for all. He prayed that they be one with Him and each other, and that they be with Him forever in glory."19

Discipleship churches are schools of prayer. Prayer is power. Every disciple needs the power of prayer in his Christian life, because the devil is attacking constantly.

Prayer is necessary to carry on God's work properly. E. M. Bounds states that:

Prayer is absolutely necessary if we want to carry on God's work properly. God has intended it to be so. The Twelve in the early church knew the importance of prayer.

\footnotetext{
${ }^{17}$ Michael W. Foss, Power Surge: Six Marks of Discipleship for a Changing Church (Minneapolis, MN: Fortress Press, 2000), 90.

${ }^{18}$ White, The Desire of Ages, 379.

${ }^{19}$ Philip Samaan, Christ's Way to Pray (Hagerstown, MD: Review and Herald, 2006), 50.
} 
In fact, when they heard the complaint that certain widows had been neglected in the daily distribution, they did not handle it all by themselves. (See Acts 6:1-2.) The Twelve called all the disciples together and told them to select seven men, 'full of the Holy Ghost and wisdom' (Acts 6:3) whom they would appoint over that benevolent work. They added this important statement: 'But we will give ourselves continually to prayer and to the ministry of the word' (Acts 6:4). They surely realized that the success of the Word and the progress of the church were dependent in preeminent sense on their giving themselves to prayer. ${ }^{20}$

\section{The Second Mark of a Disciple: Worship}

The human being was created by God for the purpose of worshiping. The last battle between good and evil will be defined by whom we worship, the Beast or God (Rev 13, 14). Therefore, the true disciple is devoted to worship the true God. Jesus said, "God is a Spirit: and they that worship him must worship in spirit and truth" (John 4:24).

Foss comments, "Since the very beginning of the church, in the days after Jesus' resurrection and ascension, the life of the community of faith has revolved around the regular gathering of believers for worship, common prayer, and eating the bread and drinking wine in remembrance of the one in whose name they gathered." 21

Worship is the linchpin of a discipleship church. It is in the gathering of God's people around the study of the Word and communion that the church affirms its calling, receives the gifts of grace, is nourished and strengthened, and is sent back into the world to love as God loves.

Worship was an essential part for the apostolic church. Luke says that the disciples, after Jesus' ascension, "returned to Jerusalem with great joy, and were continually in the temple, praising God" (Luke 24:52, 53). The book of Acts registers the

\footnotetext{
${ }^{20}$ E. M. Bounds, The Weapon of Prayer (New Kensington, PA: Whitaker House, 1996), 11, 12.

${ }^{21}$ Foss, 94.
} 
occasion when Peter and John were going to the temple at the ninth hour, the hour of prayer (Acts 3:1), suggesting that worship was something essential for them. Worship was a need for the disciples, and should be a need for us today. Besides, God is worthy to be worshipped, $\mathrm{He}$ is our Creator, and He is our Sustainer and Redeemer. The angelic hosts in heaven are delighted to worship the Lamb (Rev 5:11-14).

By worship, it does not mean only a corporate assembly that meets together once or twice a week in what is commonly referred to as a worship service, although that is involved. Such meetings and other activities are very important as expressions of true worship. However, worship is more than going to church or other places with the objective of adoring God. William Webster says, "But worship is not primarily an action as much as a state of spirit which is foundational to the activities of worship. True worship involves the entirety of one's life every day of the week. It cannot be confined to something that happens only on one or two hours in the week. True worship is a way of life. ${ }^{22}$

The Third Mark of a Disciple: Bible Reading

Not long ago, George Barna presented these statistics: (1) 91 percent of all households in the United States own at least one Bible, (2) the typical household owns three Bibles; (3) 38 percent of adults in the U.S. read the Bible in a typical week; and (4) among Bible readers, the average amount of time spent reading the Bible during an entire week is fifty-two minutes, or about ten minutes a day. ${ }^{23}$

\footnotetext{
${ }^{22}$ William Webster, The Christian, Following Christ as Lord (Carlisle, PA: The Banner of Truth Trust, 1990), 51 .

${ }^{23}$ George Barna, Data and Trends (Ventura, CA: Barna Research Group, 1998), 1.
} 
As we can see, the statistics are alarming. The new generations are not taking time to read the Word of God. That is producing weak Christians and, therefore, weak disciples. It is imperative for the disciple of Christ to go back to the Bible and deepen his or her study of the Scriptures in order to maintain a good relationship with the Lord.

Arthur W. Pink wrote, "We must have the Scriptures before we can have Christ, for they are they which testify of Him (John 5:39): where the Bible has not gone Christ is unknown." 24

\section{The Fourth Mark of a Disciple: Service}

For Foss, "Service is a key mark of discipleship." ${ }^{, 25}$ In the Old Testament, the prophet Micah challenges the people of Israel with a question, "What does the Lord require of you but to do justice, and love kindness, and to walk humbly with your God?" (Mic 6:8). The life of a disciple involves service. There are two Greek words for service. ${ }^{26}$ One is diakoneo, the other one is douleuo. Diakoneo means to minister, to render any kind of service, is translated "to serve" in Luke 10:40; 12:37; 17:8; 22:26, 27. The other word, douleuo, means to serve as a servant or slave. Servant in two directions, first to the Lord as the apostle Paul states in Rom 1:1, "Paul, a servant.of Jesus Christ, called to be an apostle, separated unto the gospel of God." Second, service one to another, as it is written in Galatians 5:13, "Because you, brothers, were marked out to be

\footnotetext{
${ }^{24}$ Arthur W. Pink, Spiritual Growth (Grand Rapids, MI: Baker Book House, 1971), 129.

${ }^{25}$ Ibid., 99.

${ }^{26}$ Paul Nathanail, "Service," New College Greek and English Dictionary (Lincolnwood, IL: NTC Publishing Group, 1996), 55, 62.
} 
free; only do not make use of your free condition to give the flesh its chance, but through love be servants one to another."

Jesus Himself gave us a good example of service. He said, "Just as the Son of Man did not come to be served, but to serve, and to give His life a ransom for many" (Matt 20:28). His service was sacrificial; He had to die to pay the price of sin. During the last supper, He washed the feet of the disciples showing not only meekness but also the importance of service. In that event, Jesus showed that He was God's Servant, and taught the disciples to wash each other's, because He was their example.

In the book of Philippians, the apostle Paul mentions that Jesus emptied Himself taking the form of a bond-servant, and being made in the likeness of men. The purpose of His servanthood was to die on the cross (Phil 2:5-8).

As followers of Jesus, disciples must also be willing to serve as Jesus did. Jesus' attitude of being humble with the purpose of service should be the disciples' attitude. This attitude is so vital that true discipleship is related to eschatological reward. In the parable of the talents, Jesus said to the faithful servants "Well done, good and faithful servant; you have been faithful over a few things, I will make you ruler over many things. Enter into the joy of your lord" (Matt 25:21,23).

The Fifth Mark of a Disciple: Spiritual Friendship

The most effective method of Christ to reach sinners was to become their friend. Jesus ate with them, went to their parties, and socialized with them (Luke 15:1,2). That was the reason the Pharisees and the Scribes criticized Him. But for Jesus, eating and drinking with sinners was a pleasure. That was His mission. He did not care what people thought about Him, because His main goal was to reach the sinner's heart. Ellen G. 
White states, "Christ's method alone will give true success in reaching the people. The Savior mingled with men as one who desired their good. He showed His sympathy for them, ministered to their needs, and won their confidence. Then He bade them, 'Follow Me'.,27

Some studies show that a high percentage of all people who come to Jesus have been introduced by a friend. Mark Cahill, in his book One Thing you Can't Do in Heaven, comments, "Studies have shown that 87 percent of all people who come to Jesus were introduced through a friend. We need to be about the business of making friends who do not know Jesus. This isn't so they can pull us away from Jesus, but so the Lord can use us to draw them to Him.. ${ }^{28}$

To be friendly is a gift from the Holy Spirit, and those who want to win souls for the Lord have to practice this virtue. Today, many new converts to the faith have left the church only because they did not find friendly members. It is the duty of a true disciple to be courteous, amicable, and friendly. These virtues make those who are attending the church feel well and help them remain in their faith. On the other hand, a rough and unsanctified character makes a person reject the offer of salvation, because those who are looking for a better spiritual life are interested in seeing if those who profess being Christians are living what they preach. Ellen G. White adds, "Love will do that which argument will fail to accomplish. But a moment's petulance, a single gruff answer, a lack

\footnotetext{
${ }^{27}$ Ellen G. White, The Ministry of Healing (Mountain View, CA: Pacific Press, 1959), 143.

${ }^{28}$ Mark Cahill, One Thing You Can't Do in Heaven (Rockwall, TX: Biblical Discipleship Publishers, 2004), 79.
} 
of Christian politeness and courtesy in some small matter, may result in the loss of both friends and influence."29

Jesus Christ should be our example in everything, especially, when we talk about discipleship. He was pure, polite, and courteous. His life was a true illustration of courtesy. Ellen G. White comments,

What Christ was on this earth, the Christian worker should strive to be. He is our example, not only in His spotless purity, but in His patience, gentleness, and winsomeness of disposition. His life is an illustration of true courtesy. He had ever a kind look and a word of comfort for the needy and the oppressed. His presence brought a purer atmosphere into the home. His life was as leaven working amid the elements of society. Pure and undefiled, He walked among the thoughtless, the rude, the uncourteous; among unjust publicans, unrighteous Samaritans, heathen soldiers, rough peasants, and the mixed multitude. He spoke a word of sympathy here and a word there. As He saw men weary, and compelled to bear heavy burdens, He shared their burdens, and repeated to them the lessons He had learned from nature, of the love, the kindness, the goodness of God. ${ }^{30}$

The practice of being friendly will increase the kingdom of Jesus on this earth.

The church will multiply more rapidly. Foss says, "It is interpersonal, caring

relationships between committed disciples that real growth takes place."31 And White adds, "If we would humble ourselves before God, and be kind and courteous and tenderhearted and pitiful, there would be one hundred conversions to the truth where now there is only one." 32

\footnotetext{
${ }^{29}$ White, Colporteur Ministry, 73.

${ }^{30}$ Ellen G. White, Testimonies for the Church 9 vols. (Mountain View, CA: Pacific Press, 1948), $9: 189$

${ }^{31}$ Foss, 103

${ }^{32}$ Ellen G. White, Welfare Ministry (Hagerstown, MD: Review and Herald, 1952), 86.
} 


\section{The Sixth Mark of a Disciple: Giving}

The true disciple is willing to give himself to the Lord. Jesus asks not only our life, our time, our talents, but also our possessions. The true disciple recognizes the Lordship of Jesus Christ. He knows that everything in life comes from the Lord. We have nothing. Everything belongs to the Lord. The purpose of giving is to teach us that giving is the law of God's kingdom. "For God so loved the world, that He gave His only begotten Son, that whoever believes in Him should not perish, but have eternal life" (John 3:16). Luke, in his gospel, said that the first disciples left everything and followed Him (Luke 5:11). To be willing to leave everything and follow Jesus is a mark of true discipleship. Matthew registered the story of the rich young man. When Jesus invited the young man to follow Him, he rejected the invitation because he did not want to get rid of his possessions (Matt 19:16-22).

Basically, the young man was not able to give his whole life to Jesus. Jesus was not asking him for his possessions. Jesus was offering him the most important opportunity in his life, to be part of His team, to be His disciple. Jesus offered the young man to fellowship with Him. Dietrich Bonhoeffer, commenting about the encounter Jesus had with the young man, says, "He went away sorrowful, disappointed and deceived of his hopes, unable to wrench himself from his past. He had great possessions. The call to follow means here what it had meant before, adherence to the person of Jesus Christ and fellowship with him. ${ }^{, 33}$

Ellen G. White wrote, "The true disciple will not live to gratify beloved self, but for Christ, and for the good of his little ones. He is to sacrifice his ease, his pleasure, his

\footnotetext{
${ }^{33}$ Dietrich Bonhoeffer, The Cost of Discipleship (New York: Touchstone, 1959), 76.
} 
comfort, his convenience, his will, and his own selfish wishes for Christ's cause, or never reign with him on his throne. ${ }^{34}$

Pastor Foss makes this commentary regarding his church and the offering issue: "In a membership-driven church the offering is analogous to the payment of dues, a fee for services received. In a discipleship church, the offering is symbolic of the giving of one's self to God who loves us with an everlasting love ... For disciples, giving should be as natural as receiving."

Even tough Foss does not include love as a characteristic of a true disciple; love is a prerequisite to all these characteristics.

\section{Conclusion}

In this chapter we have seen the most important characteristics and marks of a disciple. Obviously, there are many more qualities, such as patience, faithfulness, selfcontrol, to mention a few, that characterize the disciple of Christ. The format of this paper does not allow going into the more detailed discussion of these. However, the ones discussed, are the most significant and most needed in church today.

\footnotetext{
${ }^{34}$ White, Testimonies for the Church, 1:85, 86 .

${ }^{35}$ Foss, 103.
} 


\section{CHAPTER 4}

\section{STUDY OF DISCIPLESHIP MODELS}

The word "model" suggests something more than a two-dimensional flat diagram. According to Wikipedia a model is "a pattern, plan, representation, or description designed to show the structure or workings of an object, system, or concept. Also, it is a study of a miniature of the actual. Models may refer to abstractions, concepts, theories, representations of objects, occupations, history and culture, and are used in human and animal behavior."1 Models can be used to represent exterior forms, such as cars and planes, but they can also represent internal systems, such as the human body. In the scientific field, models are used as teaching tools, but they may also serve to suggest new direction for advanced research. For example, the discovery of the double helix model for the DNA molecule by Watson and Crick, triggered major developments in modern biochemistry and genetics.

In the field of evangelism, we also use models of discipleship. It is our intention to study various models, starting of course with the best model, the Jesus' model. Another model of interest is the Pauline' model, because Paul is one of the apostles who had vast experience dealing with evangelism in general, but he also had experience with planting churches, affirming the faith of the new believers and making disciples. Some

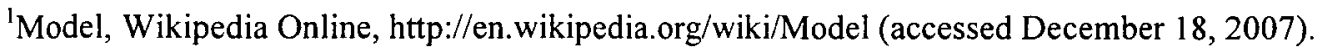


other contemporary models of discipleship will be discussed also.

\section{Jesus' Model of Discipleship}

Jesus' model of discipleship was unique. Jesus did not operate a formal school, but his disciples took quite a course. He discipled them over a three year period, not only establishing the course subject matter, but setting the pattern by which future disciples should walk. His curriculum is difficult to institutionalize because of its rigorous standards.

The process of discipling was not new to the Jewish world of Jesus. Jewish rabbis had been followed by disciples for quite some time before Jesus' arrival, but the manner by which Jesus discipled was radically different. The rabbis bound their disciples to the Torah, the Jewish Bible, and to the instruction of previous rabbis. On the other hand, Jesus bound his disciples to Himself. Jesus required His disciples to surrender without reservation to Him and to the Kingdom of God that he was inaugurating. The relationship between Jesus and the Twelve had no parallel in the Hebrew religion. The Twelve were not official brass following their governor. Being a disciple of Jesus meant nothing less than complete personal commitment to Him. The commitment to Jesus included being committed to His message of the Kingdom of God and to His method of bringing about God's Kingdom.

Jesus followed a process for making disciples. The process Jesus followed had at least six stages: praying, choosing, inviting, training, empowering, and deploying.

First Stage: Praying

The Bible records that before Jesus called his disciples, He spent the whole night 
in prayer with God: "And it was at this time that He went to the mountain to pray, and He spent the whole night in prayer with God. And when day came, He called his disciples to Him, and chose twelve of them, whom He also named apostles" (Luke 6:12, 13).

It is evident that prayer is very important for any purpose. For Jesus, the process of choosing his disciples did not depend upon himself. Jesus needed the direction of His Father and selecting His disciples was a matter of high interest. The disciples would be the base of His platform. Jesus needed a type of people with whom He could work. Jesus spent the whole night praying to His Father, because he knew that His Father would answer His prayers and would help Him to find the best men to build His church.

Ellen G. White comments on this,

He chose the stillness of night, when there would be no interruption. Jesus could heal the sick and raise the dead. He was Himself a source of blessing and strength. He commanded even the tempests, and they obeyed Him. He was unsullied with corruption, a stranger to sin; yet He prayed, and that often with strong crying and tears. He prayed for His disciples and for Himself, thus identifying Himself with our needs, our weaknesses, and our failings, which are so common with humanity. $\mathrm{He}$ was a mighty petitioner, not possessing the passions of our human, fallen natures, but compassed with like infirmities, tempted in all points even as we are. Jesus endured agony which required help and support from His Father. ${ }^{2}$

Today there is no difference. Christ is our example, so before we try to recruit disciples, we need to spend enough time in prayer with God our Father, in order to hear His voice and be blessed to find those whom He is calling to be His disciples.

What occurred in the days of Pentecost will happen when the church is focused in prayer. Multitudes were convinced about the message of salvation, and many of them were converted to Christianity and became followers and disciples of Christ. Jesus'

\footnotetext{
${ }_{2}^{2}$ Ellen G. White, God's Amazing Grace (Hagerstown, MD: Review and Herald, 1973), 167.
} 
desire is that his disciples always be faithful and loyal to him. Jesus wants his disciples to be faithful until the end. For that reason, He commanded them, "Keep watching and praying that you may not enter into temptation, the spirit is willing, but the flesh is weak" (Matt 26:41).

\section{Second Stage: Choosing}

The act of choosing has always been a divine act. God is sovereign, and $\mathrm{He}$ chooses whom He desires according to His will and wisdom. God chose Abraham from Tare's family to be the father of the Jewish nation. God chose Jacob instead of his brother Esau. In the book of Deuteronomy we find that God chose the nation of Israel among all nations:

For you are a holy people to the Lord your God; the LORD your God has chosen you to be a people for His own possession out of all the peoples who are on the face of the earth. The LORD did not set His love on you nor choose you because you were more in number than any of the peoples, for you were the fewest of all peoples, but because the LORD loved you and kept the oath which He swore to your forefathers, the LORD brought you out by a mighty hand, and redeemed you from the house of slavery, from the hand of Pharaoh king of Egypt (Deut7:6-8).

The disciples did not choose to be followers of Jesus. They probably never imagined that Jesus, the Son of God, the Messiah, could call them to be his companions in the greatest enterprise of their lives. The call to be disciples was Jesus' initiative. The disciples were not chosen on the basis of their special abilities or virtues, they were chosen on the basis of God's grace alone. Jesus' summons is an act of grace, calling unworthy sinners to follow him. He summoned the fisherman as well as the tax collector and zealot. A decisive factor is that Jesus called to himself those who, in the eyes of the majority, did not seem to have the necessary qualifications for fellowship with him.

Jesus accepted the outcast, the despised of society, and in doing this He demonstrated that 
they have been adopted into fellowship with God.

Although discipleship was a voluntary initiative with other types of masterdisciple relationships in the first century, Jesus' initiative depended on His call of those who would be His disciples.

Of course, the election of the disciples was subject to respect for the individual's freedom. Jesus made the call; the individual had to respond. This response was essential and critical. Michal J. Wilkins calls it "the pivotal response." He writes,

Once Jesus extended his call, a response has to be made. That response was the pivotal point of the person's life. From that point, a person was either a disciple of Christ or turned away from him. It was an either-or situation, because Jesus said that "who is not with me is against me" (Luke 11:23a). The response to Jesus' call involved recognition and belief in Jesus' messianic identity (John 2:11; 6:68-69), obedience to His summons (Mk 1:18,20), and a personal commitment that was undertaken after giving allegiance to Him (Mt 19:23-30; Luke 14:25-33). ${ }^{3}$

Since the individual's freedom is infected by sin, God has to work through His Holy Spirit in the disciples' mind to bring them to Jesus. Jesus said, "No man can come to me, except the Father that sent me draw him: and I will raise him up in the last day" (John 6:44). All of this tells us that the entire process of being a disciple is an act of grace, and the individual responds to a call which is a product of the Holy Spirit.

\section{Third Stage: Invitation, "Tell Them What" and "Tell Them Why"}

After Jesus chose the disciples He invited them to follow Him. He never demanded to be followed; He simply extended invitations. The disciples had to choose if they would like to follow Him. The purpose of Jesus was for the disciples to spend time with Him, in order that they could be inspired, motivated and modeled by Jesus.

\footnotetext{
${ }^{3}$ Wilkins, Following the Master, 108.
} 
According to the gospel of John, two disciples asked Jesus, "Where are you staying?" and then Jesus replied, "Come and See" (John 1:38, 39).

Bill Hull called this stage a "Come and See"" phase. This phase was an introduction to Jesus and His work. Hull adds that "five disciples followed Him, learned from Him, and then returned home to consider if they wanted to go farther." "The 'Come and See' phase is recorded in John 1:35 to 4:46; this passage is not found in the synoptic." During this phase, Jesus would teach the disciples, the "what" and the "why" of discipleship.

"The What." The "what" had to do with the core of His ministry. Jesus came to seek and to save the lost. The disciples had to understand clearly the mission. For that reason when Jesus had the encounter with the Samaritan woman, He said to His disciples, "Do you not say, 'There are four months, and then comes the harvest'? Behold, I say to you, lift up your eyes, and look on the fields, that they are white for harvest" (John 4:35).

Furthermore, on several occasions Jesus set before the disciples, the purpose of the mission. Luke recorded the Great Catch of Fish. They had returned to fishing once again. After toiling all night, Jesus ordered them to cast the net in the deep. The disciples were amazed with the results; they got a great catch. Peter realized that he was before God, because he fell at Jesus' feet saying, "Depart from me, for I am a sinful man, O Lord" (Luke 5:8). Jesus responded, "Do not fear, from now on you will be catching men. And when they had brought their boats to land, they left everything and followed

\footnotetext{
${ }^{4}$ Hull, 216.

${ }^{5}$ Ibid.

${ }^{6}$ Ibid., 191.
} 
Him" (Luke $5: 10,11)$. The disciples left everything because they had understood the reason for the task.

Another declaration of the task took place just before the twelve were commissioned. "And seeing the multitudes, He felt compassion for them, because they were distressed and downcast like sheep without a shepherd. Then He said to His disciples, 'The harvest is plentiful, but the workers are few. Therefore, beseech the Lord of the harvest to send out workers into His harvest'" (Matt 9:36-38).

Jesus caused the disciples to see the magnitude of the task. The need of workers was huge. The multitudes were dispersed; they needed direction. Immediately following this pronouncement, Jesus sent them out two by two to make the application. Jesus made that important connection between the work that needed to be done and the reason for the work. In all of these instances, Jesus was instilling in the disciples' mind the truth about the Great Commission. Bill Hull explains,

He built the disciples' convictions through a healthy portion of life experience. They had a great deal of hands-on ministry in and around the calls to reach out. The Great Commission didn't suddenly plop into the disciples' laps just prior to the ascension. It was a simple culmination of priorities already taught. For thirty-four months Jesus progressively and gradually taught the disciples what they must do.?

After His resurrection, Jesus appeared to His disciples several times. During these appearances, Jesus gave them the commands called the Great Commission:

Mark 16:15-16: "Go into all the world and preach the gospel to every creature. He who believes and is baptized will be saved; but he who does not believe will be condemned."

Luke 24:46-47: "And He said to them, 'Thus it is written, that the Christ should

${ }^{7}$ Hull, 193. 
suffer and rise again from the dead the third day; and that repentance and forgiveness of sins should be proclaimed in His name to all nations, beginning from Jerusalem."

John 20:21: "Jesus therefore said to them again, Peace be with you, as the Father has sent Me, I also send you."

Acts 1:8: "But you shall receive power when the Holy Spirit has come upon you; and you shall be My witnesses both in Jerusalem, and in all Judea and Samaria, and even to the remotest part of the earth."

Bill Hull says that the four occurrences mentioned above are a beginning but are incomplete. There is no methodology in these commands. That is why the Great Commission found in Matthew is the most often quoted. It provides a specific methodology, it gives a blueprint to follow, a prescribed plan for taking the good news to the ends of the earth. "Go therefore and make disciples of all the nations, baptizing them in the name of the Father and the Son and the Holy Spirit, teaching them to observe all that I commanded you, and lo, I am with you always, even to the end of the age" (Matt $28: 19,20)$.

The words "going," "baptizing," and "teaching" are subservient to the imperative verbal action, "make disciples." When we take all the passages concerning the Great Commission, we find that Jesus did not refer only to preaching the gospel, or baptizing people, or even making new converts. To Jesus making disciples meant the process of reproduction.

The disciple-making process is not only winning souls for Christ. It is a process of converting followers of Christ into persons whose desires are to reproduce themselves

${ }^{8}$ Hull, 194. 
and to teach others to do the same. This is a process of multiplication. Without this process it would be impossible for the church to keep pace with world population growth. A disciple can introduce another person to Jesus, and that means that he has reproduced, but if the new convert is not trained to do the same, then reproduction has taken place but not multiplication. In the Great Commission, Jesus made a call not only to reproduce but also to train those newly converted into coaches who would train others to make disciples. Jesus' call requires men and women consecrated and committed to give time, effort and money.

"The Why." During this phase Jesus explained to His disciples not only the reason of the task, which was enormous, but the passion for the mission. Jesus had told them what ought to be done, but now He needed to tell them why the task was very important. The "why" was centered in Jesus' mission. Several passages explain His mission:

John 3:16: "For God so loved the world, that He gave His only begotten Son, that whoever believes in Him should not perish, but have eternal life."

Mark 10:45: "For even the Son of Man did not come to be served, but to serve, and give His life a ransom for many."

John 12:32: "And I, if I be lifted up from the earth, will draw all men to Myself." Jesus established clearly that His mission was to die for humanity; His sacrifice would be accepted by His Father, in order to reconcile the sinner with God. This message will be the center of preaching. When the disciples preached about Jesus' sacrifice for the whole world, they were preaching the essence of salvation. The world needed forgiveness, reconciliation, and hope for their lives. Without Christ, the world was alienated from God. After Jesus' ascension, the disciples were on fire. They 
preached with power; the message was that there is salvation only through Jesus Christ. The apostle Peter exclaimed "And there is salvation in no one else; for there is no other name under heaven that has been given among men, by which we must be saved" (Acts $4: 12)$.

Fourth Stage: Training, "Show Them How," and "Do It with Them"

During this phase Jesus was dedicated to training His disciples. This phase is called by some writers as the "Come and follow me" phase. ${ }^{9}$ During this period Jesus took time for modeling, explaining, experimenting, and clarifying. The disciples had to learn new things and to unlearn old ones. Jesus was a different teacher, He said, "No one sews a patch of unshrunk cloth on an old garment; otherwise the patch pulls away from it, the new from the old, and a worse tear results. And no one puts new wine into old wineskins; otherwise the wine is lost, and the skins as well; but one puts new wine into fresh wineskins" (Mark 2:21, 22).

Teaching and training new truths would take time. Matthew 11:1 tells us that Jesus spent time giving instructions, "And it came about that when Jesus had finished giving instructions to His twelve disciples, He departed from there to teach and preach in their cities."

Bill Hull explains that the most effective teaching tool is a model. He says, They knew how to teach, because they saw Him teach. They knew how to cast out demons, pray for the sick, care for the weak, because He modeled it. They understood the importance of working through others, because He demonstrated it through them. Because it had been done to them, they could do it to others. The

${ }^{9}$ Hull, 235. 
disciple's golden rule is "you will do unto others as it has been done unto you."

Through Jesus' modeling process, the disciples learned how to teach others, and how to convert others in the disciple-making process.

The church has to be a training school. To train others in the ministry is the main task of the pastor. E. G. White comments, "Many church members would be willing to work if they were taught how to begin ... Every church should be a training school for Christian workers." 11

Philip Samaan, in his book Christ's Way of Making Disciples, cites a Gallup poll which showed "that only 10 percent of all laypersons were involved in the ministry of the church. Interestingly, 40 percent who are not involved would like to be involved, but they have never been asked to or shown how." ${ }^{\prime 2}$ LeRoy Eims says that "every pastor has in his congregation men who today are merely spectators in the kingdom of God, but who would pay any price to be involved with him in the real heart of the ministry." 13

Jesus showed the disciples how to do it, and He did it with them. This same process is a model for the church in the last generation. The disciples today must follow Jesus' example. The problem is that this task takes time and risks, and sometimes we do not want to pay the price.

${ }^{10}$ Ibid., 198.

"White, The Ministry of Healing, 148.

${ }^{12}$ Philip Samaan, Christ's Way of Making Disciples (Haggerstown, MD: Review and Herald, 1999), 74, 75. 1978), 33.

${ }^{13}$ LeRoy Eims, The Lost Art of Disciple Making (Grand Rapids, MI: Zondervan Publishing House, 
Fifth Stage: Empowering, the Promise of the Holy Spirit

Jesus knew that, without the power of the Holy Spirit, the disciples would not go further. During the training process, He taught them about the Holy Spirit. Jesus said, "But I tell you the truth, it is to your advantage that I go away, for if I do not go away, the Helper shall not come to you, but if I go, I will send Him to you. And He, when He comes, will convict the world concerning sin, and righteousness, and judgment" (John $16: 7,8)$.

The Holy Spirit would be the Person who would work to convince the world of sin. The disciples would be only channels through which the Holy Spirit would work.

When Jesus appointed the seventy to go before Him to prepare the way, the seventy were empowered by Jesus to have authority over all the power of the enemy. Luke registered Jesus' command, "Behold, I have given you authority to tread upon serpents and scorpions, and over all the power of the enemy, and nothing shall injure you" (Luke 10:19).

It was evident that without the power of the Holy Spirit, the disciples could not have success over the power of evil. No one who is disconnected from heavenly power can overcome the evil spirits. The seventy disciples had success in their mission, they returned with joy, saying, "Lord, even the demons are subject to us in your name" (Luke 10:17).

The promise of the Holy Spirit was so essential that Jesus ordered the disciples to stay in Jerusalem until they received the power from on high. Jesus said, "You are witness of these things. And behold, I am sending forth the promise of My Father upon 
you; but you are to stay in the city until you are clothed with power from on high" (Luke $24: 48,49)$.

In the book of Acts Luke recorded the words of Jesus referring to the Holy Spirit, "He said to them, 'It is not for you to know times or epochs which the Father has fixed by His own authority; but you shall receive power when the Holy Spirit has come upon you; and you shall be My witnesses both in Jerusalem, and in all Judea and Samaria, and even to the remotest part of the earth"' (Acts 1:7, 8).

Fifty days after His resurrection, the Holy Spirit descended upon the incipient church. The disciples were filled by the Holy Spirit and they began to speak in other languages. There were thousands of conversions. The disciples were equipped to start the long journey of discipleship. Then, discipleship became a lifestyle of the disciples. Only with the empowering of the Holy Spirit did the disciples accomplish the Great Commission commanded by Jesus before His ascension. Ellen G. White, comments, "After the descent of the Holy Spirit, the disciples were so filled with love for Him and for those for whom He died, that hearts were melted by the words they spoke and the prayers they offered. They spoke in the power of the Spirit; and under the influence of that power, thousands were converted."14

The Holy Spirit would be the person in charge of leading the church. The Holy Spirit would be the present, vicarious Christ. The Holy Spirit not only would lead the church, but He also would be an agent of change. Craig A. Dossman Sr. wrote,

Not only did the Spirit of God direct the church, but it also transformed the believers. In the book of Galatians 5:16 we are urged to walk in the Spirit, because the fruit that the Holy Spirit produces is love, joy, peace, patience, kindness, goodness,

\footnotetext{
${ }^{14}$ White, Acts of Apostles, 22.
} 
faithfulness, gentleness, and self-control (Gal 5:22-23 NIV). As the early church was transformed by the Spirit, it also reaped the results of being shaped by the Spirit. ${ }^{15}$

\section{Sixth Stage: Deploying}

The last phase in Jesus' discipleship process was to deploy them. The disciples had been trained for three and a half years. They were ready to do the work. The Holy Spirit had descended upon them. During the three-and-a-half-year training period, they were sent to practice what they had learned, but now, after having received the Holy Spirit, they were prepared to start the real work. The disciples had to accomplish the Great Commission. The gospel needed to be carried to the whole world. In the book of Acts, we find a pattern of discipleship multiplication:

1. Acts 2:41: Peter's Sermon on Pentecost day: 3,000 were baptized.

2. Acts 4:4: Peter's Sermon at Temple: 5,000 believed the Word of God.

3. Acts 4:32: There were a multitude of believers.

4. Acts 5:14: And believers were the more added to the Lord, multitudes both of men and women.

5. Acts 6:1: The number of disciples was multiplied.

6. Acts 6:7: And the word of God increased; and the number of the disciples multiplied in Jerusalem exceedingly.

7. Acts 11:21: And the hand of the Lord was with them: and a great number that believed turned unto the Lord.

8. Acts 17:6: The disciples had turned the world upside down.

\footnotetext{
${ }^{15}$ Craig A. Dossman Sr., From House to House, A New Testament Model for Church Growth (Lincoln, NE: BBMRC, 1994), 31.
} 


\section{The Pauline Model}

Apostle Paul was a unique disciple. He was not among the twelve, but he claimed that he was called by Jesus, and his credentials are not less than the other disciples (Gal 2:8). Nevertheless, Paul did not go in a different direction than Jesus' discipleship model. He knew that the only way to accomplish the Great Commission was to make disciples and to encourage them to follow this pattern.

Even though Paul did not teach much about discipleship, there is a passage where he outlined a discipleship model: "You therefore, my son, be strong in the grace that is in Christ Jesus. And the things which you have heard from me in the presence of many witnesses, these entrust to faithful men, who will be able to teach others also" (2 Tim 2: 1-2).

First, we notice the affection Paul had for his young Christian friend. Paul's model of discipleship was based on a personal relationship. He calls Timothy "my son."

Second, we notice the model of discipleship that Paul was passing on to Timothy. It is a model of teaching and equipping new Christians and bringing them to maturity so that they too may teach others. "What you have learned from me, teach others so that they may also teach." It is still a simple, profound principle.

Third, in this passage we find four generations of believers. First, Paul made Timothy a disciple. Timothy was then to disciple reliable men. Then these men would be qualified to teach or to disciple others.

\section{Discipleship Pyramid}

In the above passage, we can see how the apostle Paul understood the Great Commission as the base of a discipleship pyramid. It envisions one person having 
several disciples who would in turn have even more disciples and so on. There are four levels that Paul mentioned here: Paul, Timothy, faithful people, and others. It should be considered that Paul had other disciples too, such as Titus, Luke, and Silas. This pyramid chart can be pictured this way:

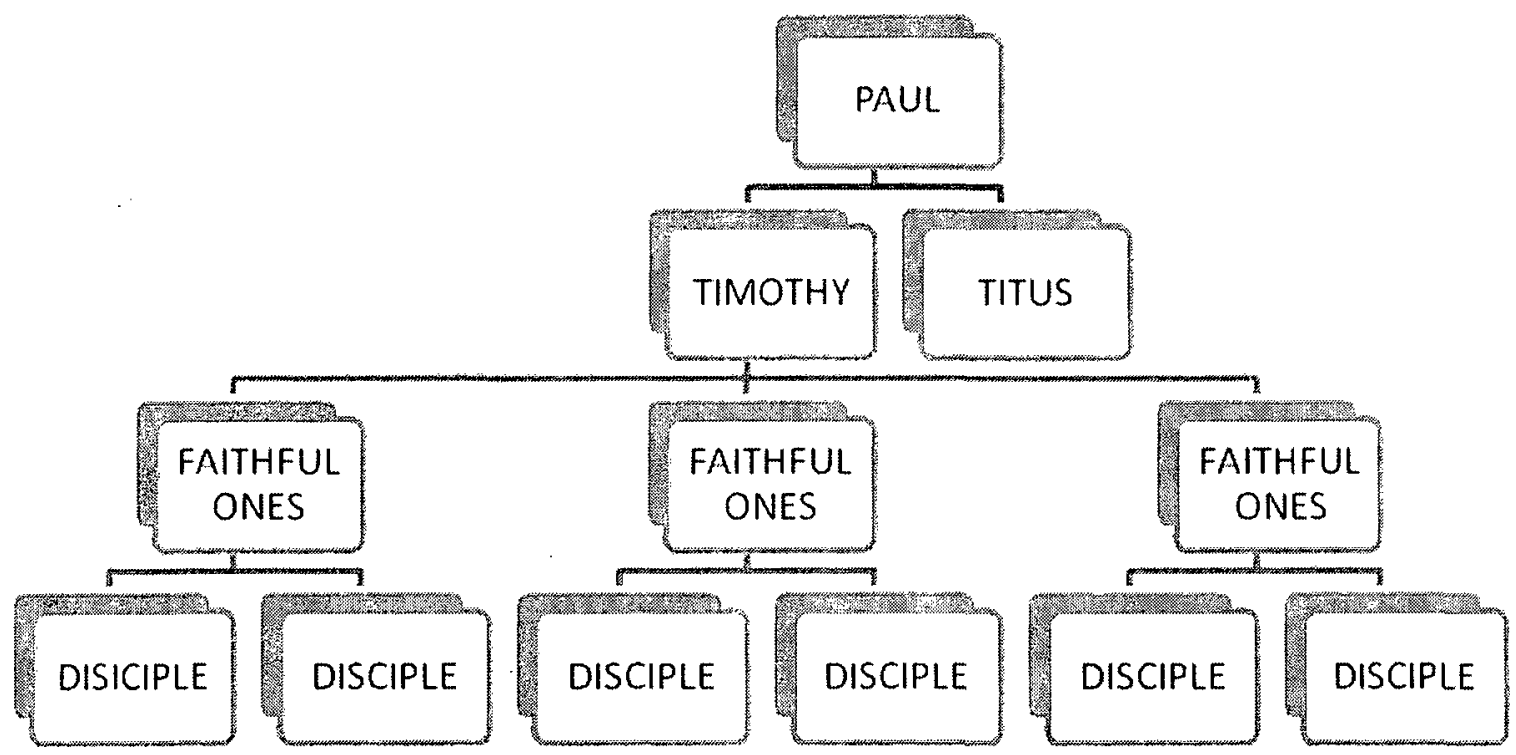

Figure 1. Discipleship Pyramid.

According to this model, the preaching of the gospel will reach the whole world. This was Paul's objective. Obviously, it is the model that the modern church has to follow in order to reach the unbelievers.

\section{Contemporary Models of Discipleship}

The G12 Model

The G12 model started in Colombia, South America, in 1983. Today, this model is a worldwide movement that has trespassed borders and it is being adopted in Europe, 
India, the United States, and other countries. The web site Reachouttrust.org describes the origin of this model like this:

César Castellanos Dominguez the pastor of a church in Colombia felt that traditional methods of growing a church were not working, so he resigned from his pastorate and began to pray about a solution. In 1983 feeling that the Lord was giving him specific direction he formed the $\mathrm{MCI}$ [Misión Carismatica Internacional or International Charismatic Mission] with the aim of reaching 200 people within 6 months. Pastor Castellanos was encouraged to be able to reach his target in 3 months. In 1986 the opportunity came to visit Dr Yonggi Cho's church in Seoul Korea. He was so impressed by the cell church method that he returned to Colombia and adapted the Yonggi Cho cell church model for his own church. The adoption of the cell church principle made a difference to Pastor Castellanos' church and by the end of 1991 there were 70 effective cells. Although confident that he was on the right lines Pastor Castellanos was not satisfied and felt he needed something which would accelerate growth. ${ }^{16}$

For Castellanos the adoption of the cell church principle gave him beneficial results. According to some observers, his church has used this discipleship principle to build the largest small group network in the world: 30,000 small groups in a single congregation. $^{17}$

The reason why this model is growing is because there are some well-known people around the world promoting it.

This new model for doing church is also growing elsewhere because a number of well-known people are involved in promoting this new church model of discipleship. In Singapore are Lawrence and Nina Khong. England has Colin and Amanda Dye at Kensington Temple. In the United States of America, we have Pr. Dick Bernal Jubilee Christian Center, Pr. Larry \& Melanie Stockstill at Bethany World Prayer Center and Pr. Ken \& Lois Gott. ${ }^{18}$

\footnotetext{
${ }^{16}$ Reachout Trust, "A Look at G12," http://www.reachouttrust.org/articles/relatedsubjects/g12.htm (accessed October 15, 2008).

${ }^{17}$ G12 Revolution, "The G12 Vision," http://g12revolution.com (accessed October 15, 2008).

${ }^{18}$ Let us Reason Ministries, "G12 - The Government of 12," http://www.letusreason.org/ Pent55.htm (accessed October 15, 2008).
} 


\section{The G12 Principle}

The G12 principle is based upon a government of twelve. According to some supporters of this movement, the number twelve is a government number.

The Principle of Twelve: Jesus' vision for the world is to "win souls and make disciples": "Therefore go and make disciples of all nations ..." (Matthew. 28:19-20). His method was to work closely together with twelve men who He mentored to take His place. The apostle Paul also mentored a number of young men (Timothys) who later became the great leaders of the New Testament Church. The mentoring principle Christ demonstrated we call the "Principle of Twelve." Why did He choose "twelve"? Twelve is the number of government in the Bible. He established His kingdom and government on the same principle that God established Israel in the Old Testament: twelve tribes. He intended to show us a pattern of how to disciple the nation. $^{19}$

\section{Methodology of Model G12}

The G12 model works this way: a pastor trains twelve people to be cell leaders.

These cell leaders are each responsible for discipling twelve others in a cell group, usually with a minimum number coming from the community and not from within the church they attend.

The G12 model facilitates the multiplication of cell groups, the training of new leaders, and the discipleship of every member of the body. The aim of the model is that everybody be involved in reaching the lost through an open cell.

The goal is for everybody to become a leader and to run his/her own open cell. Everyone is ministered to, and everyone is a minister. The cell groups do not divide instead they multiply. When a person becomes a part of a cell he or she starts to pray and fast for three non-Christians. One by one the non-Christians are led to Christ and become

\footnotetext{
${ }^{19}$ Solid Rock Ministries International, "G12 History," http://www.solidrockg 12.org/g12.html (accessed October 20, 2008).
} 
part of the cell. When the cell has grown to a certain size, multiplication takes place. Each person in the cell then starts to build a new cell. They continue to receive help, mentoring and encouragement from the original cell, but they also start their own cell. When all the members of the original cell have started their own new cell, the original cell becomes a Primary 12 group. A Primary 12 group is made up of leaders who have their own cells and meet for leadership training, to share about their progress, and meet for encouragement and support.

Everyone is encouraged to attain leadership qualification in a short period of time. People are developed into leaders through a process that is called the "Ladder of Success," which consists of winning, consolidating, discipling, and sending.

\section{The Method of Four Stages in G12 Model}

Win

New believers are added to the church through personal evangelism, weekend celebration church services, and monthly "net" meetings.

Consolidate

Both new believers and new church members are "plugged in" to the church through the consolidation process. Members of the consolidation team are assigned to new believers or new members to help enroll them in a weekly cell meeting, guide them through a short Pre-Encounter course, and register them to attend an Encounter Retreat.

\section{Disciple}

After completing the consolidation process, the new disciple enters the School of Leaders, which consists of three ten-week trimesters of study. During the second 
trimester, the students open their own cells but also continue meeting in their original cells, which become their leadership, or G-12 groups.

Send

As the disciple progresses through the School of Leaders, he opens his own cell and begins to develop his twelve, taking them through each step of the process of the vision: winning them, consolidating them, discipling them, and eventually sending them "to make disciples of all nations."

\section{Factors of Growth of G12 Model ${ }^{20}$}

These are factors which have an impact on the ability of the system to create and sustain growth:

1. Strong leadership creates a cohesive group.

2. Each leader has only a small number of people for whom he or she is responsible, and this facilitates effective discipling.

3. Because each member operates in a group of 12 , it maintains a sense of family with the dynamics of loyalty, empathy and caring while eliminating one common church problem, that of alienation.

4. It benefits from due emphasis on initial care for each new believer at rebirth.

5. It deals immediately with spiritual problems in the new life that will clear the way for a more rapid maturing.

\footnotetext{
${ }^{20}$ Reachout Trust, "A Look at G12," http://www.reachouttrust.org/articles/relatedsubjects/g12.htm (accessed October 15, 2008).
} 
6. It takes emphasis away from expensive buildings and trappings and frees finances for more efficient use.

7. It deals with the "hanger on" or "back-row" mentality and ensures that each member is active.

\section{Some Critics of G12 Model}

Some critics have suggested that this model has some difficulties, especially in the level of hermeneutic principles. The author of the article "A look at G12," says,

An important principle of hermeneutics is that we must be careful to differentiate between the clear teachings of the Bible, as understood by mainstream Evangelicals, and logical inferences drawn from it. I have no doubt that G12 has much to commend it as a method of church growth, but under the scrutiny of the Word of God some of the teaching in its support appears to be at best logical inference rather than clear biblical teaching. ${ }^{21}$

For instance, the principle of the number twelve is questioned in the same article above mentioned. The author says,

There is no doubt that the number 12 in scripture is a significant number and that it carries the meaning of government and authority among men. It figures largely in the genealogy of the Jewish nation; it has a large place in the prophetic sections of the Bible, and Jesus certainly chose 12 apostles in the pre-Christian period before he instituted the Church. Pastor César Castellanos' claim that he has had special divine revelation concerning the use of 12 in the G12 movement is impossible to refute. How can it be established whether or not a man has heard from God? What must be firmly stated however is that there is neither teaching nor precedent for this use of 12 with regard to church government in the entire New Testament. ${ }^{22}$

Other issues that cause concern are the doctrine of the movement, franchising the

G12 model, and the exclusiveness of having an International Church.

The doctrinal stand of the movement as can easily be observed belongs in the word of faith school; this is a quote from Pastor Castellanos: "Once you know the miracle you

\footnotetext{
${ }^{21}$ Ibid.

${ }^{22}$ Ibid.
} 
want and can see it clearly, you only have to give the word of authority for it to be revealed exactly as you dreamt. Then what we conquer in the spiritual realm can be brought by faith to the natural realm. And so in this way the Lord can transform the chaotic into something beautiful. He had only to decide and then speak in order to see the miracle of creation fulfilled. And we are participants in this divine nature., ${ }^{, 3}$

In other words, Pastor Castellanos' position is that they visualize the miracle which they want; which then only requires their word of authority; which is (according to them) the same authority as Christ's, to make it happen.

A concern with the franchise problem is that every church that wants to follow this model has to sign a contract with the International Charismatic Mission promising to follow their rules and use their materials. This leads to the conclusion of having an International Church with the founder as the head.

In an article written by Tricia Tillin, she cites the author Joel Cominskey about the concern regarding to the franchise problem, saying,

"Franchising is the new talk circling around the G12 world. You have to follow the entire G12 model, just as a McDonalds franchise has to follow exact standards ... This wasn't always true. When I first studied the ICM G12 strategy back in 19961997, I observed a carefree excitement and open sharing of information. Yet in 1998 and beyond, I've noticed a certain exclusivity that has progressively become more iron-clad and closed minded. ${ }^{24}$

In spite of all critics about this model, some principles can be implemented, especially those principles that help the church to grow and consolidate the new members in the church. The principle of the "Ladder of Success," which consists of winning, consolidating, discipling, and sending, is a principle that could help ostensibly to keep in the church those who otherwise would neglect the faith after being baptized.

\footnotetext{
${ }^{23}$ Ibid.

${ }^{24}$ Tricia Tillin, Croos + Word, "The Transforming Church (9)," http://www.intotruth.org/ apostasy/cell-church9.htm (accessed October 15, 2008).
} 


\section{The Jethro Model}

This is a model that is currently being used around the world for structuring the Cell Church. Its name is derived from the advice given to Moses by his father in law, Jethro. When the load became too heavy for Moses to carry on his own, Jethro suggested that Moses should restructure Israel into groups of tens, fifties, hundreds, and thousands.

From the passage of Exod 18, we read:

When his father-in-law saw all that Moses was doing for the people, he said, 'What is this you are doing for the people? Why do you alone sit as judge, while all these people stand around you from morning till evening? ...' 'What you are doing is not good. You and these people who come to you will only wear themselves out. The work is too heavy for you; you cannot handle it alone. ... You must be the people's representative before God and bring their disputes to him. Teach them the decrees and laws, and show them the way to live and the duties they are to perform. But select capable men from all the people ... and appoint them as officials over thousands, hundreds, fifties, and tens. Have them serve as judges for the people at all times, but have them bring every difficult case to you; the simple cases they can decide themselves. That will make your load lighter, because they will share it with you. If you do this and God so commands, you will be able to stand the strain, and all these people will go home satisfied" (Exod 18:14-23).

From this passage, it is clear that Moses was trying to do all the work himself. He felt that since he was God's anointed leader, all of the work rested upon his shoulders.

The counsel of Jethro not only liberated Moses to concentrate only on the 'difficult cases', but it also provided a better system of care for the people. Carl George wrote,

No one can listen to a hundred voices at once. Most leaders have a hard enough time keeping track of ten without the flock starting to feel uncared for. Further, just as Jethro's judges were unsalaried locals who did their work when they could, out of their shepherding time so church lay workers can handle only so much span of care before they themselves burn out. For these reasons, small groups that grow beyond ten need to divide. ${ }^{25}$

${ }^{25}$ Carl George, Prepare Your Church for the Future (Grand Rapids: Baker Book House, 1991), 
One of the churches that have applied this principle is the Yoido Full Gospel Church, located in Seoul Korea. This church was founded by Dr. David Yonggi Cho in 1958. This church has had an incredible growth that has become a model to be studied for many researches and copied by many congregations. Dr. Joel Cominskey, in his $\mathrm{PhD}$ dissertation, wrote,

The Korean model seems to be the most widely watched and copied model in the worldwide cell church today. Paul Cho's Yoido Full Gospel Church is credited with being the foundational model of the modern cell group movement (Hadaway, Wright, Dubose 1987:19-21). Cho's system of pastoral care (Hurston 1995:62-80) has been replicated by many pastors and churches, and his success at cell multiplication is esteemed by all. It is very hard to dispute the incredible church growth that has taken place at Cho's church. With more than 625,000 members-and 22,000 cell groups, pastor Cho's church grows at a rate of 140 new members per day. Due to this incredible growth, Cho has found it necessary to plant churches of 5,000 members (Neighbour 1990:24). ${ }^{26}$

\section{The Jethro Structure ${ }^{27}$}

This is an extract taken from the book "The Essentials of a Cell Church", found in the web site www.cellchurchonline.com. The abstract starts with "The $5 \times 5$ Structure.

\section{The 5 X 5 Structure}

This is the "classic" structure for cell churches around the world. Its major user is David Yonggi Cho, who has built the largest church in the world in South Korea.

The Cell Group in the Jethro Structure

The cell groups in the Jethro structure never grow larger than fifteen members and

\footnotetext{
${ }^{26}$ Small Groups Articles, "History of the Cell Movement," http://members.tripod.com/ celycecomiskey/new_page_2.htm (accessed October 17, 2008).

${ }^{27}$ Cell Church International, "The Essentials of a Cell Church," http://www.cellchurchonline.com/ default.cfm?nav=qa\&qa=ga\&faq=5 (accessed October 17, 2008).
} 
will multiply when they reach that figure. When the group reaches about seven to eight believers, they start training up members in the cell for ministry. Usually one of the members is identified as an intern (potential cell leader). This intern completes the leadership training and is given opportunities to lead different parts of the cell, e.g., week 1- the Welcome section; week 2- the Worship section of the cell meeting. Soon afterwards the intern cell leader will lead the whole cell meeting under the supervision of his cell leader. Once the maximum size of the cell has been reached, the cell multiplies into two cells of seven and eight members. The intern leads the new cell that has multiplied from the existing cell. These 2 new cells begin the process again and evangelize their social contacts to grow their cell Group to fifteen members and then repeat the cycle.

The Sub Zone

This structure is called the $5 \times 5$ structure because of the way that it groups cells together to form a Sub Zone. When there are five cell groups, a successful cell leader is promoted to become a sub-zone supervisor. This sub-zone supervisor serves these five cell leaders. The size of a Sub Zone is approximately fifty to seventy people. These Sub Zones are usually formed geographically, i.e., the Cell Groups are all from the same geographical area. It is important to maintain no more than five cell groups per sub-zone supervisor. If this standard is not maintained then the lack of supervision and mentoring can cause serious problems. The sub-zone supervisors are usually not paid workers, but they volunteer their services. 


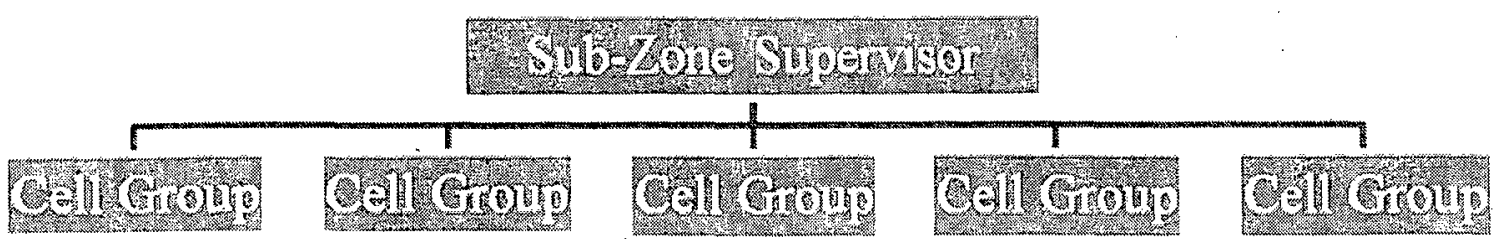

Figure 2. Sub-Zone Supervisor.

The Zone

A zone is formed when five sub-zones are grouped together. A successful subzone supervisor is promoted to become a zone pastor. This zone pastor serves these five sub-zone supervisors and their twenty-five cell groups. A zone averages about 250 people. At this level, most Jethro-structured churches hire the zone pastors full time.

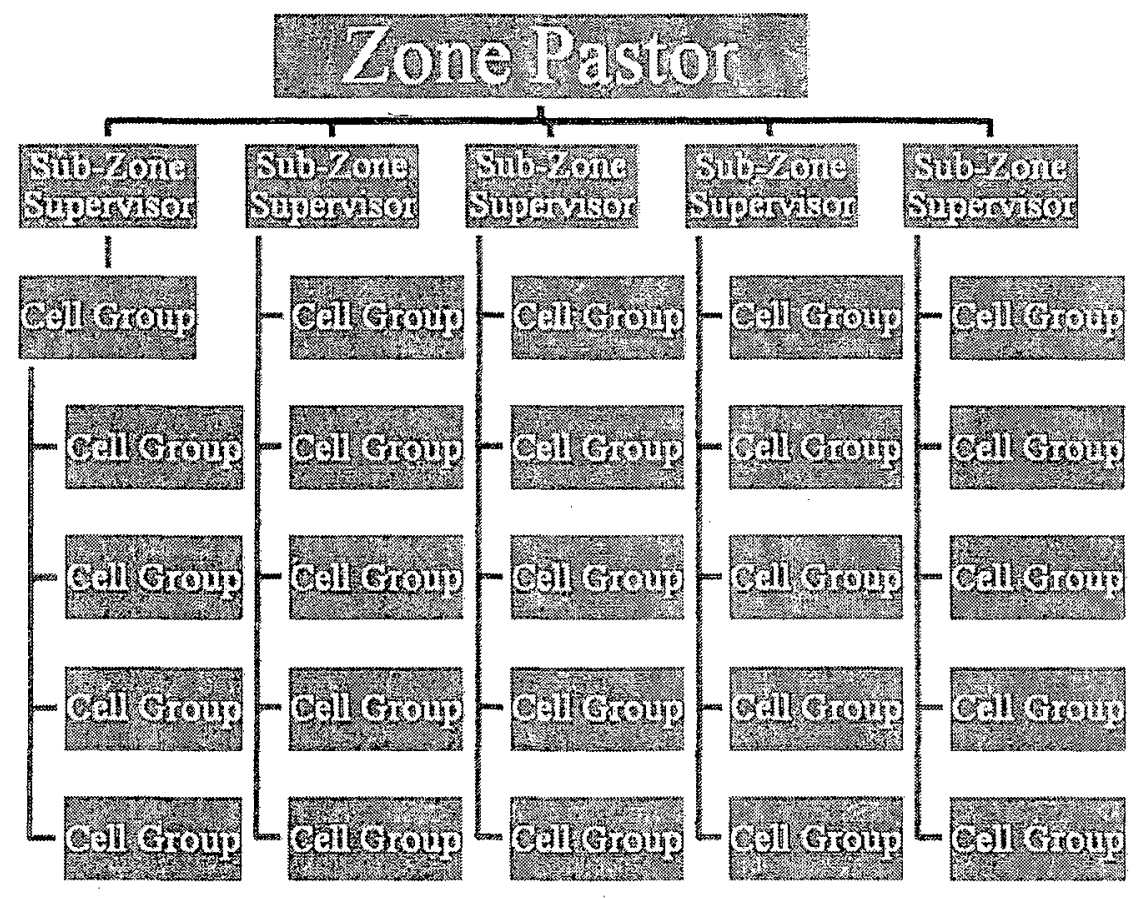

Figure 3. Zone Pastor. 
The District

A district is formed when five zones are grouped together. A successful zone pastor is promoted to become a district pastor. A district pastor serves five zone pastors, twenty-five sub-zone supervisors and 125 cell groups. An average district is at least 1,000 people.

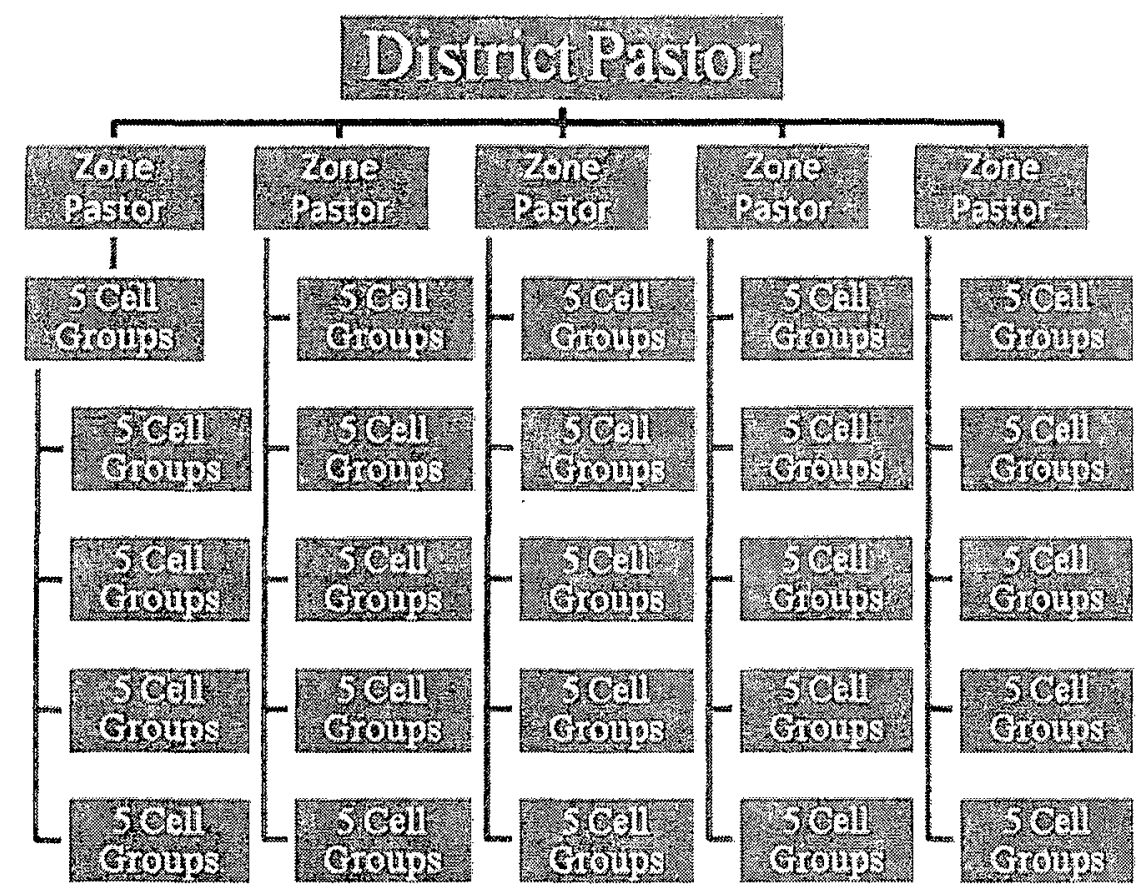

Figure 4. District Pastor.

Basic Principles of the $5 \times 5$ Model

1. There must be a comprehensive training track (for example the E1-E4 equipping steps $)^{28}$ that takes new believers to the level where they can lead cells. The time period

${ }^{28}$ E1-E4 means equipping steps: E1=Encounter 1: "Welcome to your New Family," deals with basic principles. E2=Encounter 2: "Spiritual Victory Guidebook" shares basic concepts and values on how to be free from sin. E3=Encounter 3: "Reaching the Lost" explains the great commission and how to 
for this is six months to a year. If this does not happen then, there would soon be a shortage of leaders to take the new cell groups.

2. Each Cell leader in the $5 \times 5$ structure is responsible to mentor two to three members in his cell. Out of these members the cell leader will choose his intern which will take the new cell group. Without intern leaders, the cells will not be able to multiply.

3. A constant sense of urgency must be created to see every cell member reach out to unbelievers. The structure will become ineffective if the primary purpose of evangelism is not maintained.

\section{Conclusion}

In this chapter we have seen different models of discipleship. Any model is worthless unless there is a strong willingness to put it into practice. We might conclude that the best model is an eclectic one. The principles found in the Jesus' model are vital since He is the disciple-maker par excellence. The principles found in Pauline's model are essential for the pyramid principle. The principles found in the G12 and Jethro's models are important especially in the methodology of the four stages: Win, Consolidate, Disciple, and Send.

practically win souls to the Lord. E4=Encounter 4: "Developing Your Leadership Potential" deals with important principles on how to be an effective leader. 


\section{CHAPTER 5}

\section{THE PRESENTATION OF THE SEMINAR “GO AND MAKE DISCIPLES" AT HHSDA CHURCH IN BIRMINGHAM}

\section{History of the Church}

The Hoover Hispanic Seventh-day Adventist Church started in January of 2004. The president of Gulf States Conference, Pastor Mel Eisle, and the ministerial secretary, Pastor Don Shelton, approached me in November 2003 with the plan of planting a new church in the Birmingham area. I accepted the challenge and started praying for divine help. In December 2003, I made the first visit to the area. I visited the Roebuck Seventhday Adventist Church because I was told that there were some Hispanic members attending that church. In fact, I found five Hispanic SDA members, three of them from Mexico and one couple from Puerto Rico. I visited with them and presented the plan of planting a Hispanic church in the area. They received the news with joy and embraced the idea of having a vibrant church where they could worship in their own language. We planned to have the first meeting the first week of January 2004, at the First Birmingham SDA Church in Hoover, Alabama. Pastor Adam Evans from the First Birmingham Church was very receptive and supportive. I met with the church board and they decided to help us with the usage of the church gym. An English lady, Gladys Sherrer, was very helpful to our group. She speaks Spanish and decided to join the Hispanic group. Gladys paid for some newspaper advertising to announce that a new Hispanic church would be 
starting in the English church building. The first meeting we held had about fifteen people including members and visitors.

From the beginning, the Lord has blessed the HHSDA Church. By 2008, the church's membership reached about seventy, but the leaders in the church are aware that there is much more work to do. There is an increasing Hispanic population in the city of Birmingham and its suburbs. According to the 2006 U.S. Census, the Hispanic population in Birmingham was 1.6 percent of $229,424 .^{l}$ This statistic represents only those who are in the country legally. If we add those who are here and are not residents, the total would be bigger. Due to the increase in the church's membership and the Hispanic population, it was necessary to prepare and equip the church to meet these challenges.

\section{Presentation of the Seminar "Go and Make Disciples"}

The presentation of the seminar "Go and Make Disciples" took several phases.

\section{Phase 1: Preparation}

The first step was to have a church board meeting in order to show the board members the necessity of having a training program. This church board was held during the first week of September 2008. It was voted to start a discipleship seminar as soon as the researcher would be ready with all the resources. On September 13, I preached a sermon in the church presenting the importance of the Great Commission, which is to make disciples, and the difference between a disciple and a believer. I explained that there are at least four distinctions between a disciple and a believer. 
Distinction \# 1: Abiding in the Word. This is a primary requirement to be Jesus' disciple. Jesus said, "You will know the truth. and the truth will make you free" (John 8:32) and this is often taken out of context for use in evangelism. That verse is not about salvation. It is about being a disciple. Look at the context. John 8:30 states that, "Many came to believe in Him." Then Jesus spoke directly to those believers, not to the unsaved. He spoke "to those Jews who had believed Him," and said, "If you continue in (abide in) my word, then you are truly disciples of Mine; and you will know the truth, and the truth will make you free" (John 8:31-32). Abiding is much more than visiting His Word once a week or even once a day. It is living in, being rooted in, His Word. To be His disciple, you must know and live in His Word. A Christian who does not know and abide in His word is just a believer.

Distinction \# 2: Loving one another. This is another essential requirement for being His disciple. Jesus said, "By this all men will know that you are my disciples, if you have love for one another" (John 13:35). The word translated in that verse as love is the word for unconditional love in Greek. It is the word agape as compared to the word phileo. The word phileo indicates the brotherly love of friendship. Agape love brings with it unlimited co-liability, friendship does not. Disciples truly love one another in deed and in truth, considering each other to be more important than themselves. That level of love, exemplified by Jesus, openly identifies them in the world as His disciples. However, too many Christians love one another in word but not in deed. Agape love is more than meeting together in rows in a church sanctuary or in a classroom circle. It is

\footnotetext{
${ }^{1}$ US Census Bureau, Birmingham (city) Alabama, http://quickfacts.census.gov/qfd/states/ 01/0107000.html (accessed January 21, 2009).
} 
more than meeting together in a home as part of a small group. Jesus prayed that His disciples would be one as He and the Father are one, that they might be one so that the world might know that the Father sent Him into the world (John 17:11,21-23). That oneness comes from agape love, from the distinctive love that disciples have for one another.

Distinction \# 3: Bearing fruit. This is another primary requirement for becoming and being His disciple. Simply stated, a disciple bears fruit. A fruitless disciple is a contradiction of terms. A fruitless Christian is just a believer. Jesus said, "By this is My Father glorified, that you bear much fruit, and so prove to be my disciples" (John 15:8). The word translated from Greek as "prove" in that verse means to become, come into existence, begin to be, or be made. An appropriate translation of that verse could be, "By this is My Father glorified, that you bear much fruit, and so become my disciples." What are the fruits? From the context of John 15, the fruits are new believers and disciples. It is not simply the fruit of the Spirit (Gal 5:22-23). The fruit of John 15 is the fruit of the branch abiding in Jesus the vine. The branch abiding in the vine and bearing fruit is the one becoming His disciple.

Distinction \# 4: Following Him at great cost. Believers come to Jesus. Disciples also follow Him. The cost for someone to come to Jesus (become a believer) was fully paid by Jesus. The cost of following Jesus (being His disciple) is paid by the one who follows. It is costly to follow Jesus, to be His disciple. Paying the price is a requirement for His disciples. Jesus defined the cost in Luke 14:25-33. In the first three verses, we see two types of people among those who were going along with $\mathrm{Him}$, those who come to Him, and those who could come after Him (i.e., they follow Him). 
Disciples do more than come to Him, they follow Him. They pay the price to follow the One who paid the ultimate price for them.

After having motivated the church to participate in a discipleship seminar where they were going to learn more about discipleship principles, I began to collect the material that was going to be used during the seminar. On December 13, 2008, I met with the church board to define the best date to present the seminar. The date that was voted was January 16-21, 2009.

Phase 2: The Presentation of the Discipleship Seminar

"Go and Make Disciples"

The presentation of the discipleship seminar "Go and Make Disciples" started Friday, January 16,2009 , at 7:00 p.m. at the HHSDA Church in Birmingham, Alabama. Before I started the presentation of the first lesson I reviewed the objectives and purpose of the seminar with the participants.

\section{Purpose}

The purpose of the Discipleship Seminar "Go and Make Disciples" is to awaken the church members regarding the main task of the church, which is to preach the gospel and fulfill the Great Commission of making disciples.

\section{Objectives}

1. That each participant understand the concept of discipleship.

2. That each participant learn the difference between a disciple and a believer.

3. That each participant become a committed witness for Christ. 
4. That each participant improve his/her devotional life, having a deeper relationship with Jesus through praying and Bible study.

5. That each participant learn about the different models of discipleship.

6. That each participant participate in missionary work.

After discussing the purpose and objectives of the seminar, we then looked at the order of the program to be developed each night. The program to be followed was:

1. Song service

2. Bible reading

3. Prayer

4. Short devotional

5. Instructions and filling out 2 forms: Informed Consent Form and PreSeminar Questionnaire (only the first session)

6. Lecture

7. Questions and comments

8. Closing hymn

9. Closing prayer

10. Dismissal

\section{The Seminar Lessons}

The lessons that were presented during the seminar were the following:

1. What Is a Disciple?

2. The Difference between a Disciple and a Believer

3. Jesus' Definition of a Disciple

4. Marks of a Disciple 


\section{Models of Discipleship}

\section{The Dynamic of Presentation}

The presentation of the lessons took about forty-five minutes every night for five consecutive nights. After the preliminaries, I had a short devotional of about three to four minutes. I chose a Bible passage that had to do with the topic to be discussed that night, and then we entered directly into the lesson study. I usually asked a participant to read the first question or statement. When a Bible passage was read, I asked a participant what they understood about that passage. Sometimes a participant raised his/her hand to give the answer. At the end of the lesson there was a worksheet to be completed. The purpose of completing the worksheet was to reinforce the concepts and teachings of the lesson. Before finishing the lesson I gave a chance for questions and answers clarifying doubts. Finally, we closed by singing a missionary hymn and praying.

\section{Timetable of the Presentations}

1. Friday night: Lesson 1 -What Is a Disciple?

2. Sabbath morning (Worship Service): Sermon Title - "A Call to be a Disciple"

3. Sunday night: Lesson 2-The Difference between a Disciple and a Believer

4. Monday night: Lesson 3-Jesus' Definition of a Disciple

5. Tuesday night: Lesson 4-The Marks of Discipleship

6. Wednesday night: Lesson 5-Models of Discipleship

\section{Summary of Each Presentation}

Lesson 1: What Is a Disciple?

The purpose of this study was to help the student to understand the origin and 
meaning of the term "disciple" in order that he/she could comprehend the importance of being a true, committed disciple. During this lesson we explored in detail the Great Commission passage of Matt 28:18-20. We emphasized that Jesus did not send His disciples to make believers or converts, Jesus sent His disciples with a specific order, to make disciples.

Lesson 2: The Difference between a Disciple and a Believer

The purpose of this lesson was to explain the difference between a disciple and a believer. It is true that every disciple is a believer, but not every believer is a disciple. The following chart explains not only the plain truth that every disciple is a believer but not every believer is a disciple, but also explains the reality that, in most churches, there are more believers than disciples. In the following chart we can see in an illustrated way the difference between believers and disciples.

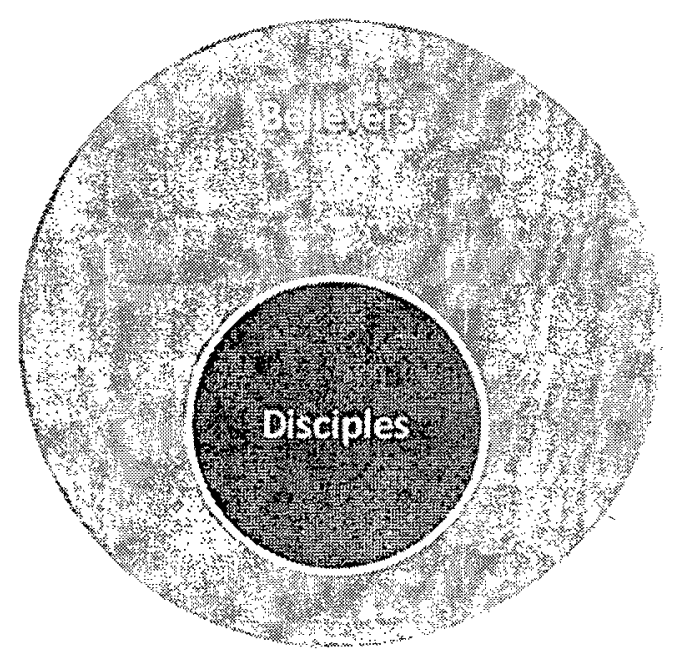

Figure 5. Difference between a Disciple and a Believer. 
In this lesson we studied that there are four major differences between disciples and believers:

1. A disciple is somebody who is very committed to the Word of God.

2. Disciples love one another as Jesus loved them.

3. A disciple bears fruit.

4. A disciple is willing to pay the cost.

Lesson 3: Jesus' Definition of a Disciple

The purpose of this lesson was for the church member to understand what a disciple is according to Jesus' definition. In this lesson, we studied that, since Jesus was a disciple-maker par excellence, He outlined seven basic principles about discipleship:

1. The disciple makes Jesus pre-eminent in his life (Luke 14:26-33).

2. The disciple has to remain in the Word of God (John 8:31).

3. The disciple is willing to deny himself, take up his cross daily, and follow Him (Luke 9:23).

4. The disciple is a reproduction of his Master (Matt 10:24, 25).

5. The disciple loves others as Christ loves them (John 13:34, 35).

6. The disciple is obedient to the Lord's commandments (John 14:15).

7. The disciple makes other disciples (Matth 28:19, 20; John 15:8).

Lesson 4: The Marks of a Disciple

The purpose of this lesson was to emphasize that the true disciple is somebody who has distinctive characteristics or marks. We studied the six basic marks of a disciple:

1. Prayer 
2. Worship

3. Daily study of the Bible

4. Service

5. Spiritual Friendship

6. Giving

Lesson 5: Models of Discipleship

The purpose of this lesson was to teach the church members the models of discipleship and let them decide what model is most suitable for them. During this lesson we learned about four models:

1. Jesus' model.

2. Pauline model.

3. Jethro model.

4. The G12 model.

In this lesson the members were challenged to make radical changes and work aggressively in missionary work. We learned that if a single person is committed to the Lord and is sent to the mission field where there are no Adventists, this person could plant a church of 59,049 in ten years (see chart in lesson 5).

Another good principle we learned in this lesson was the "Ladder of Success" from the G12 model. This "Ladder of Success" has four steps:

1. Winning

2. Consolidating

3. Discipling

4. Deploying 
If these steps are followed by the new converts, they will remain in the church as consolidated members and committed disciples. The members at HHSDA Church were excited about these principles because they did not want to lose members. They want to retain, as much as possible, those who enter the church with their first love for Jesus.

Finally, in this lesson we also studied the principle of the cell group. Jesus started His church by calling not a big crowd but a small group. Jethro's model shows the concept of the cell group.

Joel Comiskey says that the three major components of all cell groups include:

1. Seeking God (worship, prayer, lesson).

2. Developing relationships with one another (ice-breaker, ministry to one another, refreshment time).

3. Reaching out to non-Christians (friendship evangelism, special cell activity). ${ }^{2}$ With some of the principles learned during the seminar, we decided to organize the church into four cells or groups of thirteen members, following the principle of Jesus and the G12 model.

\section{Phase 3: Organizing the Church}

The seminar was concluded on Wednesday night, January 21, 2009. After concluding the seminar, we called for a meeting the following Sunday, January 25, 2009, in order to have enough time for organization. We met at 9:00 a.m. and, after having a short devotional and prayer, we started the process of organizing the church.

\footnotetext{
${ }^{2}$ Joel Comiskey, Cell Church Strategies, Strategies of Cell-Based Ministry Today, http:// comiskeypark.tripod.com/ cell_church_strategies.htm (accessed January 25, 2009).
} 
Step 1: The first step was to choose four leaders called "Discipler-Elders." These leaders are in the first level of the four levels of discipleship (see figure 1). The purpose was to divide the church into four groups. Each group has thirteen members including the "Disiciple-Elder." These groups are called "Matrix Cells."

Step 2: In this step, the "Discipler-Elder" had to choose three "DisciplerLeaders." The "Disciple-Elder" is in charge of supervising his three "Discipler-Leaders." Each "Discipler-Leader" has to render a report to his supervisor (Discipler-Elder).

Step 3: In this step, the "Discipler-Leader" chose three "Disciplers." In this stage we had a matrix cell formed by thirteen members. From this point forward we now have three sub-groups in the matrix cell that are called "Cell-Daughters."

Step 4: In this step, each cell daughter that is composed of four members looks for Bible studies. The goal is that each member of the cell have at least two persons having Bible studies. If that goal is reached, each matrix cell will have twenty-six persons having Bible studies. Eventually, when those prospects make a decision for Jesus and are baptized, they will become new disciples.

\section{Levels of Discipleship}

The following chart shows the hierarchy that works in the matrix cell. The "Discipler-Elder" is the one who is in charge of the whole group. Then the "DiscipleLeader," who has under him three "Disciplers" and every "Discipler" will be giving Bible studies in order to have two "New Disciples." 


\section{Discipler- Elder}

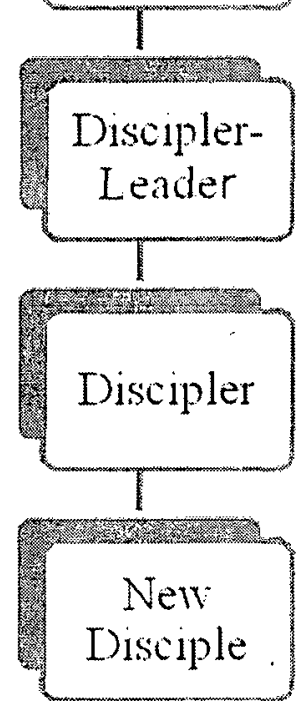

Figure 6. Four Levels of Discipleship.

\section{Matrix-Cell}

The "Matrix-Cell" is a group of twelve members of the church under the supervision of an elder. The purpose of this cell is to be structured for cohesion and support: moral, spiritual, and logistic. Each member of this cell, including the elder, has the goal to reach two new disciples.

The following chart explains the structure of the "Matrix-Cell." 


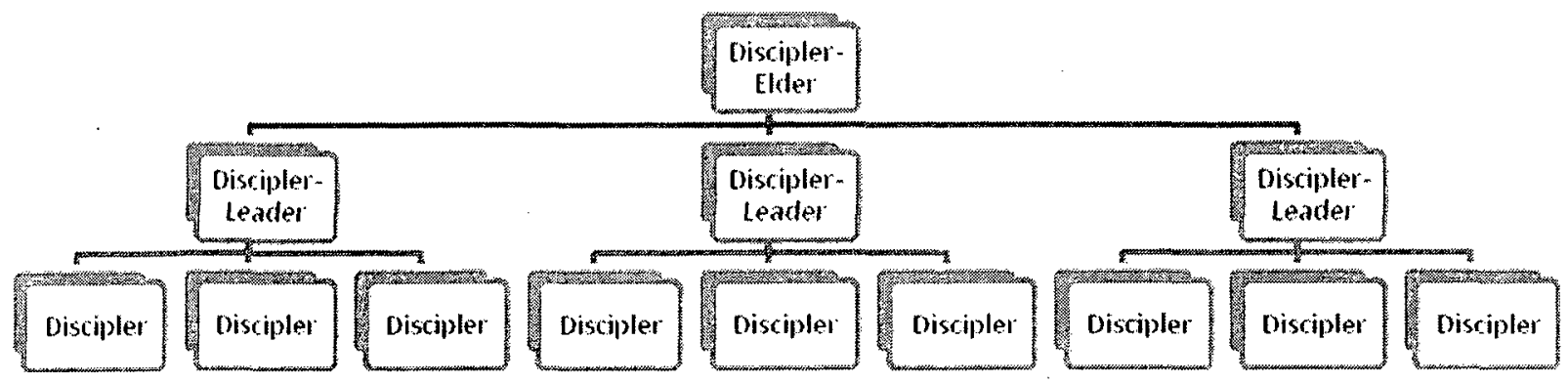

Figure 7. Matrix-Cell.

\section{Cell-Daughter}

The "Matrix-Cell" is divided into three "Cell-Daughters." The "Cell-Daughter" is led by the "Discipler-Leader." The "Discipler-Leader has three "Disciplers" under his supervision. The goal for this group is for each member to reach two new disciples, including the supervisor. That means that the "Cell-Daughter" would have eight new disciples.

The following chart shows the structure of the Cell-Daughter. 


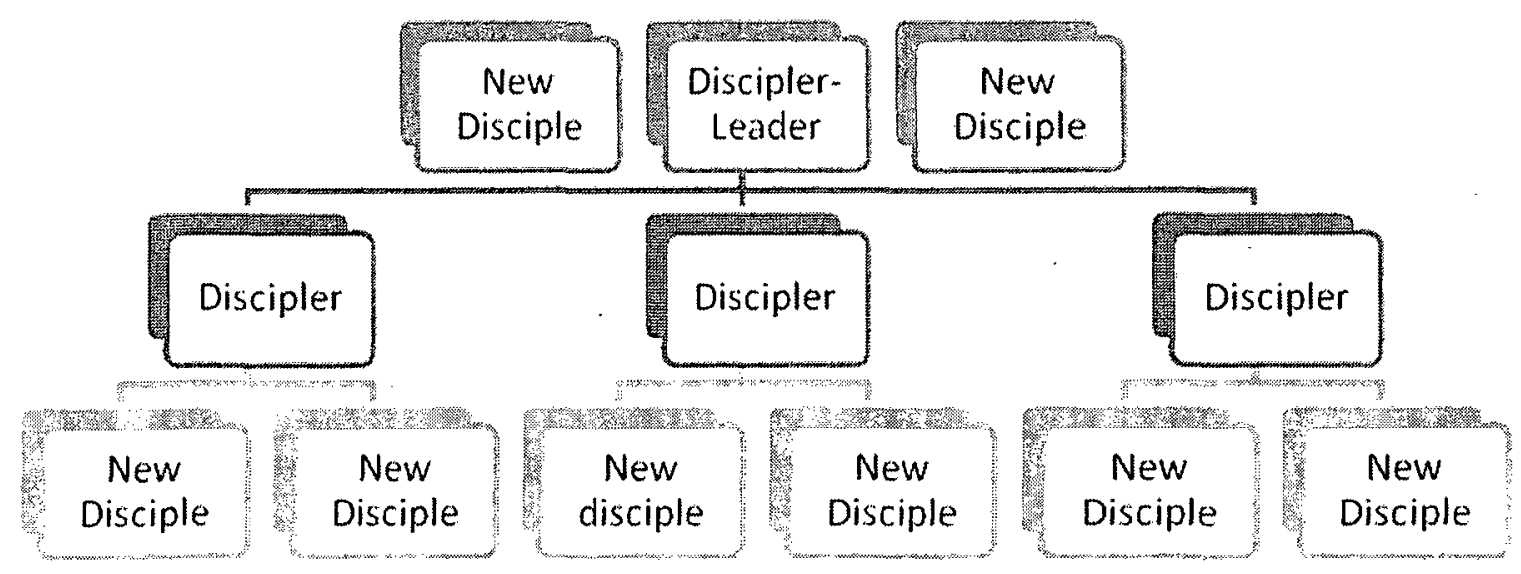

Figure 8. Cell-Daughter.

\section{Conclusion}

The experience of having had the Discipleship Seminar "Go and Make Disciples" at the HHSDA Church was positive and profitable. Most members were encouraged and motivated to work for Jesus. At the end, we close with a call to surrender our lives to Jesus and ask Him to send His Holy Spirit to bless and lead the church. We ended the seminar on Wednesday night, January 21, 2009. The same week, on January 24, 2009, the church had scheduled an evangelistic meeting. It seems that the motivation from the classes taken from the seminar caught the spirit of church members, because the first night of the evangelistic meetings the church was packed and more than thirty-five visitors were registered.

The church members were very supportive in bringing visitors every night. The meetings ended on Saturday night, January 31 . The results were wonderful一ten 
precious souls were baptized and more than twelve visitors made their decision to continue studying the Word of God for future baptism. 


\section{CHAPTER 6}

\section{SUMMARY AND RECOMMENDATIONS}

The purpose of this thesis was to develop a seminar of discipleship based upon biblical principles and the writings of E. G. White. In addition, the purpose of the discipleship seminar was to teach, train, and equip the saints of the HHSDA church in Birmingham, Alabama. The research and findings of this project will be discussed in this final chapter. Those findings and experiences encountered during the seminar as well as the results of the seminar and the recommendations for further study will be summarized.

\section{Summary}

The starting point of this thesis was the Great Commission in Matt 28:19-20. In this passage Jesus gave the command "Go and Make Disciples." Jesus never said, "Go and make believers, converts or followers." Even though each true disciple has to be a believer, follower, and convert, Jesus' command was very specific. Jesus knew that unless the process of making disciples took place, the goal of reaching the world with the gospel would be impossible. The understanding of this concept in the church is pivotal.

The Greek word for disciple is "mathetes" from the verb "manthanein" which means, "to learn." The word disciple was not only used for Jesus' followers. Moses, John the Baptist and the Pharisees also had disciples. Myung Soo Cho says, "In the Gospels, the term mathetes (disciple) is applied not only to the followers of Jesus but also 
to those of John the Baptist, the Pharisees and Moses."1

To be a follower and disciple of Jesus implied a different paradigm. Jesus was a different teacher and He demanded more from His disciples. Cho adds,

The verb manthano (learn) is used chiefly in the Gospels. The scribes understood manthano as the academic study of the written and oral Torah. However, Jesus taught that genuine Torah learning was based on a relational aspect, which included the acceptance of Jesus as the scatological messianic Torah the Jews had expected. Jesus' claim as the scatological Torah teacher indicates that manthano means the surrender of one's own judgment or will to obey the will of God. This leads to obedience to Jesus and His teachings. ${ }^{2}$

Jesus defined a disciple as one who loves others reciprocally, remains in the Word of God, makes Him preeminent in his life, is willing to deny himself, reproduces His character, obeys His commandments, and is willing to make disciples.

Jesus definition of a disciple is understandable, He was an excellent disciplemaker, and wants us to follow His example.

Jesus called His disciples to follow Him, to be with Him, and to learn from Him. The process of making disciples took three-and-a-half years for Jesus. At the end of this period, the disciples were trained and equipped by their Master to accomplish the mission. The disciples only had to wait for the outpouring of the Holy Spirit. Pentecost came, and the disciples were filled with the Holy Spirit. The results were amazing. The apostle Peter preached a sermon in which 3,000 people were convinced by the Holy Spirit and were baptized.

Through these acts, Jesus created a new paradigm of discipleship. Jesus' goal was to save the person. The disciples themselves had to experience salvation in order to

\footnotetext{
'Myung Soo Cho, "Christ-centered Discipleship: A Biblical Concept of Religious Education" (PhD dissertation, Andrews University, 1990), 169.

${ }^{2}$ Ibid.
} 
share with others what they had. That was the case with the paralytic who sat at the gate called "beautiful" when Peter told him: "Silver and gold I do not have, but what I do have I give you: In the name of Jesus Christ of Nazareth, rise up and walk" (Acts 3:6).

What is required in order to be a disciple? The concept could be expanded upon at length, but the following citation more succinctly describes it:

Are there distinct characteristics that describe disciples of Christ? Who can become one of His disciples?

First of all, a disciple of Jesus Christ is someone who has accepted by faith God's free gift of salvation. The word disciple refers to a follower of Jesus, a learner, or a pupil. So, in order to be a follower of Jesus, one must believe His Gospel and accept it by faith. Disciples of Christ display other characteristics as well:

Commitment - 2 Corinthians 4:8-11 says, "We are hard pressed on every side, but not crushed; perplexed, but not in despair; persecuted, but not abandoned; struck down, but not destroyed. We always carry around in our body the death of Jesus, so that the life of Jesus may also be revealed in our body." When troubles come into a disciple's life, he or she does not become troubled or fall into despair. Instead the disciple displays commitment and overcomes the trial through Jesus Christ. Even when he or she faces intense opposition, commitment prevails.

Consecration - Romans 12:1-2 says, "Therefore, I urge you, brothers, in view of God's mercy, to offer your bodies as living sacrifices, holy and pleasing to God-this is your spiritual act of worship. Do not conform any longer to the pattern of this world, but be transformed by the renewing of your mind. Then you will be able to test and approve what God's will is-his good, pleasing and perfect will." Consecration is the act of setting apart or dedicating someone or something for God's purposes. A disciple is consecrated unto the Lord.

Perspective - Colossians 1:24 says, "Now I rejoice in what was suffered for you, and I fill up in my flesh what is still lacking in regard to Christ's afflictions, for the sake of his body, which is the church." A disciple of Jesus Christ has an eternal focus and is not overcome with thoughts of the past or present. ${ }^{3}$

In addition to the above characteristics of a disciple, the six marks of a disciple were discussed: (1) daily prayer, (2) worship, (3) Bible reading, (4) service, (5) spiritual friendship, and (6) giving.

\footnotetext{
${ }^{3}$ All About Following Jesus, Disciples of Christ, http://www.allaboutfollowingjesus.org/disciplesof-christ-faq.htm (accessed February 10, 2009).
} 
A true disciple is someone who sets time apart for personal devotion, prayer, and Bible reading. The first three marks are in the vertical level, because the disciple is having communion with God. Service, spiritual friendship, and giving have to do with the horizontal level, because the disciple is dealing with people. The apostle Paul mentions that he had the marks of Christ, "From now on let no one trouble me, for I bear in my body the marks of the Lord Jesus" (Gal 6:17). It is obvious that the marks that Paul is talking about are the attacks, trials and hardships that he endured during his ministry for Jesus' sake. Paul was persecuted several times. He was scourged, beaten, jailed, stoned and finally executed by the Roman Empire (2 Cor 11:23-27).

In this dissertation four basic models of discipleship were discussed: (1) Jesus' model, (2) the apostle Paul's model, (3) Jethro's model, and (4) the G12 model.

In Jesus' model, I found that, for Jesus, discipleship meant a total surrender to Him. For Jesus, discipleship was not an event but a lifestyle, a long journey in which every day the disciple would reflect the life of his Master. At the same time, the disciple would produce fruits for the Kingdom of Heaven bringing others to Jesus and teaching them to also be disciples.

In the Apostle Paul's model, I found the multiplication principle. It was necessary, during the early church, that the disciples take their work seriously. The book of Acts records that church growth was extraordinary, saying, "And the Lord added to their number daily those who were being saved" (Acts 2:47).

Among the contemporary models, I found Jethro's model and the G12 model. Both models have revolutionized the church growth movement around the world. Both models are based on the cell and small group concept. The small group or cell concept 
gives to the church unity, cohesiveness and structure. The most relevant principle found in these models was the "Ladder of Success" which contains four steps: winning, consolidating, discipling, and sending.

If the four steps of the "Ladder of Success" are followed, the chances of losing members who initially come to the church are minimal. These principles will help the church to retain members and to avoid apostasy.

\section{Experience and Results during the Seminar}

The presentation experience of the seminar "Go and Make Disciples" at the HHSDA church was a blessing. The members were receptive and they were willing to learn about this new concept: discipleship. During the seminar they learned that to be a disciple is different from being just a simple member of the church. They also learned that the only way to see the church grow is through a real commitment to the Lord. Jesus is still calling people to accept His invitation and expects His followers to become His disciples.

During the presentation of the seminar "Go and Make Disciples," I emphasized the four permanent principles found in the Great Commission:

1. Permanent Power (Matt 28:18)

2. Permanent Discipleship Process (Matt 28:19)

3. Permanent Teaching Process (Matt 28:20)

4. Permanent Divine Presence (Matt 28:20)

After Jesus' resurrection, He received all power in heaven and on earth. The disciples' task of making disciples was guaranteed to be successful. Jesus would empower them with His Holy Spirit. The promise of that power would be a warranty of 
the success for the disciples in the process of making disciples. The teaching process would become continuous as the apostle Paul did with Timothy ( $2 \operatorname{Tim} 2: 1-2)$. Then, the divine presence would accompany those who faithfully would accomplish the commission.

\section{Results}

The results of the discipleship seminar "Go and Make Disciples" were quite positive. Thirty-eight people were registered the first night. They filled out the consent form and the pre-seminar questionnaire. Most of the members who were registered attended the whole seminar, except for a few who missed some of the lessons for occupational reasons. At the end of the seminar, twenty-six members finished the course and took the "Seminar Evaluation." Twenty-two of the twenty-six said they were more motivated to work for Jesus due to the seminar (see Seminar Evaluation-Results, appendix C). Some of them made the following comments:

(a) "The seminar was excellent."

(b) "I learned the difference between a disciple and believer."

(c) "The seminar was very helpful to me."

(d) "The seminar helped to wake me up regarding my spiritual condition."

(e) "I would like to learn more about discipleship."

(f) "We need more seminars like this."

(g) "The seminar was biblical."

(h) "The seminar helped me in my spiritual life. It would be good if all church members would come."

(i) "With the Lord's help, I will try to be a good disciple." 
On February 15, 2009, one month after the conclusion of the discipleship seminar "Go and Make Disciples," the post-seminar questionnaire was given to the participants. From the 38 registered, 29 filled out the post-seminar questionnaire. From the total, 20 out of 29 (69 percent) answered that a disciple is a person who makes disciples. Twentyeight out of 29 ( 97 percent) answered that there is a difference between a disciple and a believer. Forty-five percent have won souls for Jesus, and 34 percent are actually giving Bible studies.

Most of the members are taking time to study the Word of God and are praying. As a result, the attendance at church is significant; 76 percent attend all the church services. Seventy-nine percent said that it is easy to talk about Jesus with other people, and all 29 attendees ( 100 percent) responded by saying that the seminar improved their understanding about discipleship and helped them to develop new skills for witnessing.

\section{Recommendations}

The assumption of this thesis was that most members in our SDA churches are not witnessing for Christ because they have not understood the implications in the Great Commission given by Jesus before His ascension. The SDA church has been winning souls, and we praise the Lord for that, but rarely making disciples. Many people are being added to the church as believers but few as disciples, and unless there is a change in the paradigm the promise of the second coming of Jesus could be delayed (Matt 24:14).

Bertrand L. Melbourne puts it this way:

Matthew 28:19, 20, the Great Commission, contains Jesus' last instructions to His disciples. After three and a half years of training, He commissioned them to go and give to others what $\mathrm{He}$ had given to them. This essentially is the ultimate mission of 
discipleship. While the commission was given to the original disciples, it was not theirs alone. The commission was for them, their successors, the successors of their successors, and thus, disciples of every age. This says it is inclusive in its scope and timeless in its application. ${ }^{4}$

The participation of all believers is needed in the accomplishment of the Great

Commission. Ellen G. White wrote,

The Saviors' commission to the disciples included all the believers. It includes all believers in Christ to the end of time. It is a fatal mistake to suppose that the work of saving souls depends alone on the ordained minister. All to whom the heavenly inspiration has come are put in trust with the gospel. All who receive the life of Christ are ordained to work for the salvation of their fellow men. For this work the church was established, and all who take upon themselves its sacred woes are thereby pledged to be co-workers with Christ. ${ }^{5}$

Bertrand L. Melbourne adds that

The commission Jesus gave to the disciples on the Galilean mountain prior to His ascension is four dimensional. The disciples were instructed to go, make disciples, baptize, and teach. This suggests that discipleship cannot be static or sedentary. The gospel must be taken from place to place. Discipleship involves going where people are to take the gospel to them. ${ }^{6}$

After having studied and researched the theory and principles of discipleship in the Bible and in the E. G. White writings, and having discussed these principles during the discipleship seminar, some recommendations are suggested for those who want to use these principles and teachings in their ministry:

1. It is recommended that each church should have the Great Commission as the core of its mission statement.

2. It is recommended for every church to designate disciple-making as its

${ }^{4}$ Bertrand L. Melbourne, Called to Discipleship: Lessons from the Life of Jesus (Nampa, ID: Pacific Press, 2007), 110, 111.

${ }^{5}$ White, The Desire of Ages, 822.

${ }^{6}$ Melbourne, 111. 
primary goal and formulate plans and methods to accomplish the task.

3. It is recommended to mobilize, as long as possible, all church members for involvement in discipleship.

4. It is recommended to institute a permanent program of discipleship training.

5. It is recommended to discover the types of people living in the community surrounding the church and their needs. The creation of bridge-building programs that will break down the barriers and will make it easier to reach them.

6. It is recommended to develop programs that will assist members, especially new converts, to discover, develop and use their spiritual gifts. This will help members a have a deeper commitment to Christ.

7. It is recommended for pastors and church leaders to develop leadershiptraining programs to equip those who have leadership skills to lead small groups or cells.

8. It is recommended for pastors and church leaders to structure the membership of the church in small groups or cells following the principles found in Jethro's and G12 models.

9. It is recommended for pastors and church leaders to follow the principles found in the Apostle Paul's model according to 2 Tim 2:1-2. Following these principles will increase the membership.

\section{Conclusion}

Jesus' order to His disciples, "Go and make disciples," is still the order for His church in the 21 st century. It is no easy task, but Jesus, the Son of God, the Almighty, the Alpha and Omega, the One who won the victory on Calvary's cross for all those who 
believe in Him, promised to be with us until the end of the world. Jesus is our best example in everything, we should follow His example, and Ellen G. White says that the best method is Jesus' method: "Christ's method alone will give true success in reaching the people. The Savior mingled with men as one who desired their good. He showed His sympathy for them, ministered to their needs, and won their confidence. Then He bade them, 'Follow Me." "7

${ }^{7}$ Ellen G. White, The Ministry of Healing (Mountain View, CA: Pacific Press, 1959), 102. 
APPENDIX A

SEMINAR LESSONS 


\section{DISCIPLESHIP SEMINAR FORMAT \\ “GO AND MAKE DISCIPLES” \\ Presenter: Pastor Ezequiel Osorio}
A. Song service
B. Bible reading
C. Prayer
D. Short devotional
E. Lecture
F. Questions and Answers
G. Final Thoughts
H. Announcements

I. Prayer

J. Dismissal 


\section{HANDBOOK}

\section{CONTENTS}

\section{DISCIPLESHIP SEMINAR: "GO AND MAKE DISCIPLES"}

1. What is a Disciple?

2. The Difference between a Disciple and Believer.

3. Jesus' Definition of a Disciple.

4. Marks of a Disciple.

5. Models of Discipleship 


\section{DISCIPLESHIP SEMINAR \\ "GO AND MAKE DISCIPLES"}

\section{BY}

\section{PASTOR EZEQUIEL OSORIO}

Welcome to the Discipleship Seminar "Go and Make Disciples." The purpose of this seminar is to help you understand the concept of discipleship according with the Word of God, in order that you can become a true disciple of Christ who can testify to Him and be a true soul winner.

This seminar is composed of five topics as you can see in the handbook. Each topic will be covered in one session which means that we are going to have five sessions or classes.

This seminar is composed in a manner that provokes each student to think. Each question assumes a variety of answers. Some questions do not have the "right" answer and are principally designed to elicit thoughtful and meaningful application. The questions at the end of the seminar are designed to inspire the students to explore the biblical passages more thoroughly in order that they can be more effective in the ministry. The true disciple is the one who takes time every day to be more prepared, not only for-himself/herself but to help others to be ready for the most glorious event, the Second Coming of our Lord Jesus Christ.

It is our hope that this seminar can help every member in our church (HHSDA) to be a more effective disciple for Christ and also to help other individuals who can use this material that was prepared with the objective of helping our members accomplish the 
Great Commission: "Go therefore and make disciples of all the nations, baptizing them in the name of the Father and of the Son and of the Holy Spirit" (Matthew 28:20). 


\section{Discipleship Seminar}

"Go and Make Disciples"

LESSON 1

\section{WHAT IS A DISCIPLE?}

Purpose:

The purpose of this study is to help the student to understand the origin and the meaning of the term "disciple" in order that the student can comprehend the importance of being a true committed disciple.

\section{Objectives}

1. The disciple will understand that being a disciple involves dedicated discipline and pursuit of the purposes of our Heavenly Father.

2. The disciple will see that discipleship is both an Old and New Testament principle.

3. The disciple will experience a reinforcement of the principles Jesus had in mind for reaching the world.

\section{Definition}

I. Origin of the word disciple: The Greek word mathetes (disciple) comes from the Greek verb manthano, which means "to learn."

II. A disciple is: A learner who submits to discipline or one who becomes a disciplined learner. 
III. The following variables are descriptions of a disciple - one who truly follows Jesus.

A) A disciple is a learner, Proverbs 9:8-10; Matthew 4:19; John 6:6066. As such, he is open and teachable. He does not have an attitude of "knowing it all." Learning and growing is a lifetime venture.

B) A disciple is one who has made a firm commitment to the Lordship of Jesus, putting Him first in every aspect of his life. This commitment is for a lifetime, Matthew 6:9-13, 24, 33; Luke 9:23; John 13:13; 2 Corinthians 5:15.

C) A disciple is committed to a life of obedience, 1 Corinthians 6:1920; Ephesians 4:22-5:5.

D) A disciple has a daily devotional time and is developing his prayer life, Psalm 27:4; 42:1-2; Mark 1:35; Luke 11:1-4.

E) A disciple demonstrates faithfulness and a desire to learn and apply the Word of God through hearing it preached and taught, reading it frequently, studying the Bible, memorizing Scripture, and meditating on the Scriptures, John 8:31; Acts 17:11;

Colossians 3:16; 2 Timothy 2:15.

F) A disciple has a heart for witnessing, gives his testimony clearly, and presents the Gospel regularly with increasing skill, Matthew 28:18-20; Acts 1:8; Romans 1:16; 1 Thessalonians 2:4. 
G) A disciple is a regular attendee of church services where his spiritual needs are met and where he makes a contribution to the body of believers, Psalm 122:1; Acts 16:5; 1 Corinthians 12:1227; Hebrews 10:25.

H) A disciple has fellowship regularly with other believers, 1 John $1: 3$.

I) A disciple is a servant and is actively engaged in helping others in practical ways, Act 6:1-4.

J) A disciple honors God with his finances, 1 Corinthians 16:1-2.

K) A disciple practices spirituality and demonstrates the fruit of the Spirit in his life, Galatians 5:22-23.

\section{Worksheet}

This is a careful look at Scripture and what it means to be a disciple. You are encouraged to look up the following verses and see the characteristics of a disciple.

A. Please read Matthew 28:19-20, and answer the following questions:

1. Who gave the order to preach thegospel?

2. Jesus said: "Go and Make

3. To whom did Jesus say to make disciples?

4. How can we makedisciples 
B. Matthew 28: 18-20 teaches us four permanent principles:

1. Permanent Power

2. Permanent Discipleship Process

3. Permanent Teaching Process

4. Permanent Divine Presence

C. Please read Matthew 10:1-15, and answer the following questions:

1. How many disciples did Jesus call/appoint?

2. Can you name the disciples?

3. What was the mission Jesus gave to His first disciples?

a)

b)

c)

D. According to the following passages, mention the different backgrounds of the disciples:

1. Mark 1:16-20: Peter, Andrew, John and James were:

2. Matthew 9:9: Matthew was

3. Luke 6:15: Simon was

E. Did Jesus have only male disciples or did he also have female disciples? Read Acts 9:36. Name of this female disciple: 
F. Jesus used some parables to illustrate discipleship. He said that the disciples are: 1) Matthew 5:13: , and (2) Matthew5:14

G. In order to accomplish the commission of preaching the gospel, what did the disciples need to receive? Acts $1: 8$ :

\section{Reflections}

According to the above cited:

1. What will be the major adjustments you need to make in your life in order to be a true disciple of the Lord Jesus?

2. Some have considered the cost of discipleship too great. Where are you in relation to this cost? 


\section{Discipleship Seminar}

"Go and Make Disciples"

LESSON 2

\section{THE DIFFERENCE BETWEEN A DISCIPLE AND A BELIEVER}

\section{Purpose}

The purpose of this lesson is to explain the difference between a disciple and a believer. It is true that every disciple is a believer, but not every believer is a disciple.

\section{Objectives}

1. The disciple will understand that a disciple is more than a believer in Jesus Christ.

2. The disciple will understand that being a disciple is being fully committed to the Lord Jesus Christ.

3. The disciple will understand that to be a disciple is a process of growing spiritually.

4. In this lesson we will study the four major differences or distinctions between a disciple and a believer.

\section{Distinctions}

1. Abiding in the Word: This is a primary requirement for His disciples — one specifically stated by Jesus. "You will know the truth, and the truth will make you free" (John 8:32). John 8:32 is often taken out of context for use in evangelism; however, that verse is not about salvation. It is about being a disciple. Look at the context. John 8:30 states that "many came to believe in Him." Then Jesus spoke 
directly to those believers, not to the unsaved. He spoke "to those Jews who had believed Him" and said, "if you continue in (abide in) My word, then you are truly disciples of Mine; and you will know the truth, and the truth will make you free" (John 8:31-32). Abiding is much more than visiting His Word once a week or even once a day. It is living in, being rooted in, His Word. To be His disciple, you must know and live in His Word. A Christian who does not know and does not abide in His Word is just a believer. Do you really know His Word? Is your life rooted in His Word? Do you abide in His Word, or are you just a visitor?

2. Loving one another. This is another essential requirement for being His disciple. Jesus said, "By this all men will know that you are my disciples, if you have love for one another" (John 13:35). The word translated in that verse as "love" is the word for unconditional love in Greek. It is the word "agape" as compared to the word "phileo." The word "phileo" indicates the brotherly love of friendship. Agape love brings with it unlimited co-liability; friendship does not. Disciples truly love one another in deed and in truth, considering each other to be more important than themselves. That level of love, exemplified by Jesus, openly identifies them in the world as His disciples; however, too many Christians love one another in word but not in deed. Agape love is more than meeting together in rows in a church sanctuary or in a classroom circle. It is more than meeting together in a home as part of a small group. Jesus prayed that His disciples would be one as He and the Father are one, that they might be one so that the world might know that the Father sent Him into the world (John 17:11, 21-23). That oneness comes from agape love-from the distinctive love that disciples have for one another. Jesus said, "This is My 
commandment, that you love one another, just as I have loved you. Greater love has no one than this that one lay down his life for his friends. You are My friends if you do what I command you" (John 15:12-14).

3. Bearing fruit. This is another primary requirement for becoming and being His disciple. Simply stated, a disciple bears fruit. A fruitless disciple is a contradiction of terms. A fruitless Christian is just a believer. Jesus said, "By this is My Father glorified, that you bear much fruit, and so prove to be My disciples" (John 15:8). The word translated from Greek as "prove" in that verse means to become, come into existence, begin to be, or be made. An appropriate translation of that verse could be, "By this is My Father glorified, that you bear much fruit, and so become My disciples." What is the fruit? From the context of John 15, the fruit is new believers and disciples. It is not simply the fruit of the Spirit (Galatians 5:2223). The fruit of John 15 is the fruit of the branch abiding in Jesus the vine. The branch abiding in the vine and bearing fruit is the one becoming His disciple. The disciple is an instrument to bring the lost to Jesus. The believer is happy just to be one of the fruits.

4. Following Him at great cost. Believers come to Jesus. Disciples also follow after Him. The cost for someone to come to Jesus (become a believer) was fully paid by Jesus. The cost for following after Jesus (being His disciple) is paid by the one who follows. It is costly to follow Jesus, to be His disciple. Paying the price is a requirement for His disciples. Jesus defined the cost in Luke 14:25-33. In the first three verses, we see two types of people among those who were going along with Him: those who come to Him, and those who could follow after Him. Disciples 
do more than come to Him; they follow after Him. They pay the price to follow after the One who paid the ultimate price for them.

\section{Worksheet}

Discipleship has a high cost. Only true disciples are willing to pay that price.

Unfortunately, those who are only believers don't make any effort to pay that price.

\section{The cost of discipleship}

1. Read Luke 14:25-33. Find out the four levels of the cost of discipleship.
A. First level (Luke 14:25-26): the cost of relationship
B. Second level (Luke14:26): the cost of oneself
C. Third level (Luke 14:26, 27): a costly decision (Notice the emphatic negative exclusion "cannot be My disciple" in both Luke 14:26 and 27 of the one who will not pay the price to follow after Him.)
D. Fourth level (Luke 14:33) A disciple's open hand. (Jesus continued to explain the cost as, "So then, none of you can be My disciple who does not give up all his own possessions.")

\section{Believing is important, but it is not enough}

1. Read James $2: 19,20$

What is the difference between a believer and a disciple? 


\section{The difference between believers and disciples chart}

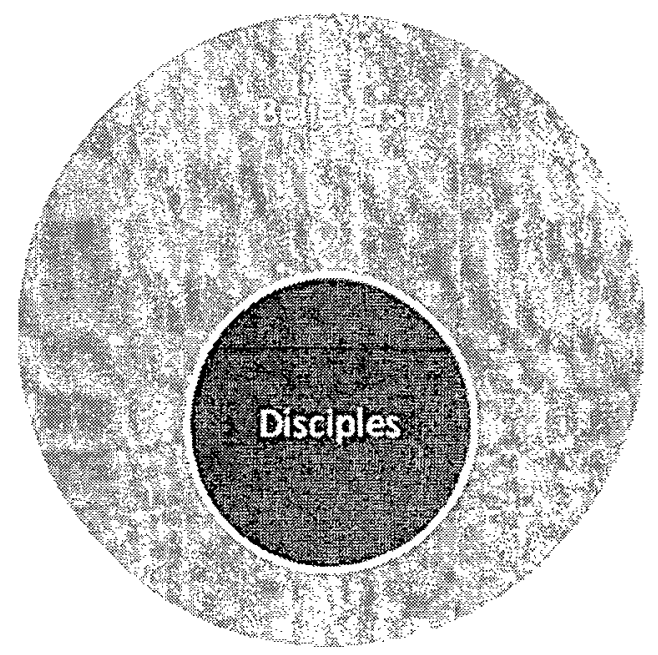

\section{Summary}

1. Jesus told us to make "disciples" of all nations-not "believers" or "converts." 2. According to James $2: 19$, mere "believers" have no better standing of faith than demons.

3. The difference between a believer and a disciple is: A believer merely believes he doesn't need to practice the Word; disciples have a deep desire to learn, obey and grow.

4. Disciples are not as apt to fall into deception and self-delusion. They are more likely to discover all that God has for them; mere believers probably will not.

5. Believers stay spiritual babes; disciples grow up spiritually. 


\section{Discipleship Seminar \\ "Disciple or Believer"}

\section{Lesson 3}

\section{JESUS' DESCRIPTION OF A DISCIPLE}

\section{Purpose}

The purpose of this lesson is that the church member can understand what a disciple is according to Jesus' description.

\section{Objectives}

1. The church member will comprehend what Jesus meant when He called his disciples.

2. The church member will be challenged to follow what Jesus taught.

3. The church member will understand the reward of being a true disciple.

\section{How Jesus Describes a Disciple}

Since Jesus was the disciple maker by excellence, his description of disciple is the most important factor in defining a disciple. Christ was speaking to the disciples when He gave the Great Commission to the church. He said, "Make disciples." Jesus suggested seven basic essentials for becoming a disciple:

1. The disciple makes Jesus preeminent in his life (Luke 14:26-33).

2. The disciple has to remain in the Word of God (John 8:31).

3. The disciple is willing to deny himself, take up a cross daily, and follow Him (Luke 9:23).

4. The disciple is a reproduction of his Master (Matthew 10:24, 25).

5. The disciple loves others as Christ loves them (John 13:34, 35). 
6. The disciple is obedient to the Lord's commandments (John 14:15).

7. The disciple makes others disciples (Matthew 28:19, 20; John 15:8).

\section{Worksheet}

1. How does a disciple make Jesus preeminent in his life?

2. What is meant by the word "hate" in Luke 14:26?

3. What is the requirement to be a true disciple that Jesus mentioned in Luke 14:33?

4. In John 8:31 Jesus gave another condition to be a true disciple, which is:

5. Luke 9:23 mentions three conditions Jesus established to be a disciple. What are they?

6. Read Matthew 10:24-25. What is Jesus saying regarding disciples?

7. In John $13: 34,35$, what commandment did Jesus give his disciples as another sign of true discipleship? 
8. In John 15:1-8 Jesus established other principles to be a disciple. What are they?

9. In John 15:14 Jesus called his disciples "friends" under what circumstances?

10. In Matthew 28:19-20 Jesus said that a true disciple makes another disciple. How did the disciples do it?

\section{Reflections}

a. According to Jesus' definition of a disciple, do you believe you are a disciple, or a simple believer?

b. Would you like to move to a higher scale to accomplish the requirements Jesus established to be a disciple?

c. Are you willing to commit to the work of the Lord and make disciples for Jesus? 


\section{Discipleship Seminar}

"Go and Make Disciples"

Lesson 4

\section{Marks of a Disciple}

\section{Purpose}

The purpose of this lesson is to show that besides the concept of a disciple according to Jesus, the Bible mentions the marks of a disciple.

\section{Objectives}

1. The church member will understand more deeply the characteristics and marks of a disciple.

2. The church member will recognize his/her actual condition and will be challenged to make some changes.

3. The church member will understand that it is imperative to have these characteristics and marks to be a productive disciple.

\section{The Marks of a Disciple}

1. Prayer

2. Worship

3. Daily study of the Bible

4. Service

5. Spiritual Friendship

6. Giving 


\section{Worksheet}

1. Prayer was an important practice of the disciples. According to Luke 11:1, what was Jesus doing and what did the disciples ask him?

2. According to Matthew $26: 41$, why is it very important to pray?

3. Worship is fundamental in discipleship. Find three examples in the Bible where the disciples worshipped Jesus.
a. Luke 5:8
b. Matthew 28:17
c. Matthew 14:33:

4. Read John 5:39. What did Jesus recommend to his listeners?

5. Read Matthew 4:1-10. How did Jesus confront the temptations?

6. Jesus mentioned service as a key element in the discipleship. Read Matthew 20:25-28. What did Jesus tell his disciples and what was his example?

7. Having friends is very important in making disciples. Jesus gave us an example of friendship when He visited the Lazarus' home. Why do you believe that we have to have friends in order to make disciples? 
8. Jesus said that a true disciple gives up everything he has. What does God want us to give?

Proverbs 23:26

Malachi 3:8-10

Matthew 6:31-33

9. What was the condition for the rich young ruler to follow Jesus? Read Matthew 19:16-21:

\section{Reflections}

1. How many of these characteristics do you have?

2. What can you do to improve your close relationship with Jesus to be a true disciple?

3. Would you like to make some changes in your life? If yes, what are they? 
Discipleship Seminar

"Go and Make Disciples"

Lesson 5

\section{Models of Discipleship}

\section{Purpose}

The purpose of this lesson is to teach the church members the Models of

Discipleship and let them decide what model is more suitable for them.

\section{Objectives}

1. The church member will learn the practical concept of discipleship.

2. The church member will understand that it is important to follow a pattern in discipleship.

3. The church member will be prepared to practice a better method of making disciples.

\section{Models of Discipleship}

1. The Jesus Model

2. The G12 Model

3. The Jethro Model

4. The Pauline Model

\section{The Jesus Model}

\section{Jesus invested time}

How much time did Jesus invest in forming His 12 disciples? 


\section{The Process}

Jesus followed a process to make disciples. This process had at least six stages:

1. Praying

2. Choosing

3. Inviting

4. Training

5. Empowering

6. Deploying

\section{Stages}

\section{Praying}

Jesus spent the whole night praying before he chose His disciples.

That means that if we want to make disciples, we have to pray earnestly too.

\section{Choosing}

Jesus chose His disciples. We have to ask Him to choose for us.

\section{Inviting}

Jesus invited His disciples to follow Him. He never used any form of pressure.

\section{Training}

Jesus did not send His disciples without training.

\section{Empowering}

Jesus empowered His disciples with the Holy Spirit.

\section{Deploying}

In this stage the disciple becomes an apostle. 


\section{The G12 Model}

\section{History}

This model began in Colombia, South America in 1983 with Pastor Cesar Castellanos. At this time, his congregation has approximately more than 300,000 people.

\section{The G12 Principle}

The letter G stands for Government. The G12 principle is based in a government of twelve.

\section{Methodology}

The methodology is based on what they called the "Ladder of Success," which consists of winning, consolidating, discipling, and sending.

\section{Winning}

During this stage new converts are brought to the church through personal evangelism.

\section{Consolidating}

In this stage the new converts are being cared for by a consolidating team. Their work is to nurture them into the Word of God.

\section{Discipling}

During this phase the new convert learns the process of discipleship, and he is prepared to become a leader. 


\section{Sending}

The new convert is deployed to open his own cell of 12 new converts and teach them to start the process of discipleship in order that they can become disciplers.

\section{The Jethro's Model}

This is a model that is currently being used around the world for structuring the Cell Church. Its name is derived from the advice given to Moses by his father in law, Jethro. When the load became too heavy for Moses to carry on his own Jethro suggested that he should restructure Israel into groups of tens, fifties, hundreds, and thousands. Read Exodus 18: 14-23 and answer why Jethro advised Moses to divide the people in different groups:

\section{The Pauline Model}

\section{Introduction}

This model is based on the Apostle Paul's teachings.

\section{Methodology}

The methodology is very simple. It is based on the passage of 2 Timothy 2:1-2:

"You therefore, my son, be strong in the grace that is in Christ Jesus. And the things which you have heard from me in the presence of many witnesses, these entrust to faithful men, who will be able to teach others also." 


\section{The Discipleship Pyramid Method}

The apostle Paul envisions the Great Commission. One disciple makes another disciple. The new disciple has to do the same.

2. The four levels:
a) Paul
b) Timothy
c) The Faithful Ones
d) The Others (Disciples)

\section{The Pyramid Chart}

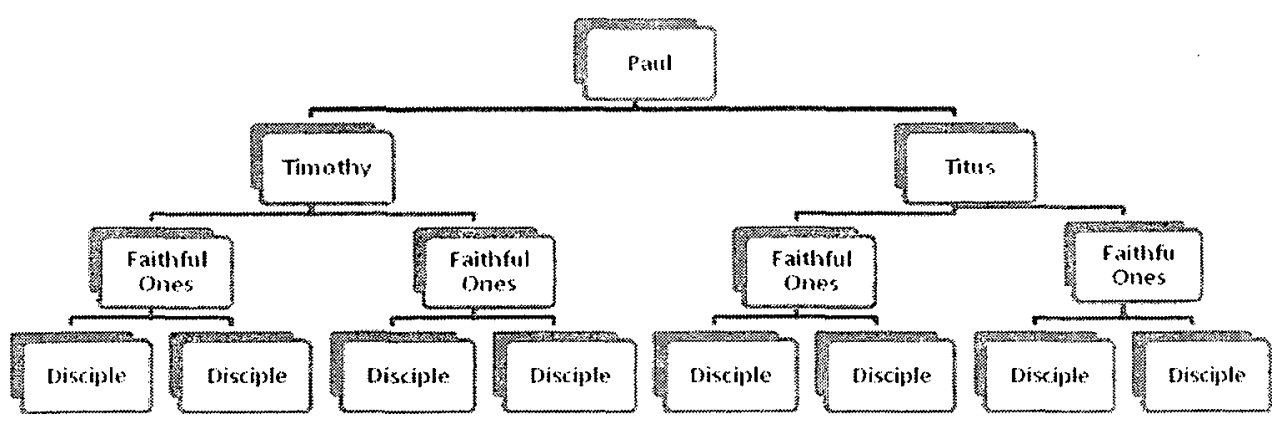


IV. How to have a 59,049 member church in 10 years

\begin{tabular}{|c|l|c|c|}
\hline Year & New Disciples per Year & $\begin{array}{c}\text { Plus } \\
\text { Previous } \\
\text { Disciples }\end{array}$ & $\begin{array}{c}\text { Total Disciples } \\
\text { at the End of } \\
\text { the Year }\end{array}$ \\
\hline $1^{\text {st }}$ & 1 disciple makes 2 disciples & 0 & 3 \\
\hline $2^{\text {nd }}$ & 3 disciples make 6 disciples & 3 & 9 \\
\hline $3^{\text {rd }}$ & 9 disciples make 18 disciples & 9 & 27 \\
\hline $4^{\text {th }}$ & 27 disciples make 54 disciples & 27 & 81 \\
\hline $5^{\text {th }}$ & 81 disciples make 162 disciples & 81 & 243 \\
\hline $6^{\text {th }}$ & 243 disciples make 486 disciples & 243 & 729 \\
\hline $7^{\text {th }}$ & $\begin{array}{l}729 \text { disciples make 1,458 } \\
\text { disciples }\end{array}$ & 729 & 2,187 \\
\hline $8^{\text {th }}$ & $\begin{array}{l}2,187 \text { disciples make 4,374 } \\
\text { disciples }\end{array}$ & 2,187 & 6,561 \\
\hline $9^{\text {th }}$ & $\begin{array}{l}6,561 \text { disciples make 13,122 } \\
\text { disciples }\end{array}$ & 6,561 & 19,683 \\
\hline $10^{\text {th }}$ & $\begin{array}{l}19,683 \text { disciples make 39,366 } \\
\text { disciples }\end{array}$ & 19,683 & 59,049 \\
\hline
\end{tabular}

\section{SUMMARY}

We hope every one of the members who has taken this seminar will be encouraged to work for Jesus in order to fulfill the commandment of the Great Commission. 
APPENDIX B

QUESTIONNAIRES 
Discipleship Seminar

"Go and Make Disciples"

\section{Pre-Seminar Questionnaire}

Instructions

Circle or write the appropriate answer that best describes your knowledge of the following questions.

1. What is a disciple?
a) A pastor
b) A lay member
c) A teacher
d) A believer
e) A follower of Christ
f) An evangelist
g) One who makes disciples
h) Don't know

2. Is there any difference between a disciple and a believer? $\mathrm{R}$ :

3. During your Christian life how many new converts have you won for Jesus?
a) 0
b) $1-5$
c) $5-10$
d) More than 10

4. Are you presently witnessing to anyone?
a) Yes
b) No

5. How much time are you spending in reading the Word of God daily?
a) Less than an hour
b) An hour
c) More than an hour

6. How much time are you spending in prayer daily?
a) Less than an hour
b) An hour
c) More than an hour

7. How often do you come to church?

a) From time to time 
b) Only on Saturdays

c) All the services

8. In a scale from 1 to $\mathbf{1 0}$ what is your participation in the church?

$\begin{array}{llllllllll}\mathrm{R}: 1 & 2 & 3 & 4 & 5 & 6 & 7 & 8 & 9 & 10\end{array}$

9. Do you find it easy to dialogue with others about Christ?
a) Yes

b) No

10. If you had the opportunity to learn more about how to be a disciple for Jesus, would you attend a discipleship seminar?

a) Yes

b) No 
Discipleship Seminar

"Go and Make Disciples"

\section{Post-Seminar Questionnaire}

\section{Instructions}

Circle or write the appropriate answer that best describes your knowledge of the following questions.

1. What is a disciple?
a) A pastor
b) A lay member
c) A' teacher
d) A believer
e) A follower of Christ
f) An evangelist
g) One who makes disciples
h) Don't know

2. Is there any difference between a disciple and a believer? $\mathrm{R}$ :

3. During your Christian life how many new converts have you won for Jesus?
a) 0
b) $1-5$
c) $5-10$
d) More than 10

4. Are you presently witnessing to anyone?
a) Yes
b) No

5. How much time are you spending in reading the Word of God daily?
a) Less than an hour
b) An hour
c) More than an hour

6. How much time are you spending in prayer daily?
a) Less than an hour
b) An hour
c) More than an hour

7. How often do you come to church?

a) From time to time 
b) Only on Saturdays

c) All the services

8. In a scale from 1 to 10 what is your participation in the church?

$\begin{array}{llllllllll}\mathrm{R}: 1 & 2 & 3 & 4 & 5 & 6 & 7 & 8 & 9 & 10\end{array}$

9. Do you find it easy to dialogue with others about Christ?
a) Yes

b) No

10. Did the seminar improve your understanding of discipleship and help you to develop new witnessing skills?
a) Yes
b) No 
APPENDIX C

EVALUATIONS AND RESULTS 
Discipleship Seminar

"Go and Make Disciples"

\author{
RESULTS \\ Pre-Seminar Questionnaire
}

\title{
Instructions
}

Circle or write the appropriate answer that best describes your knowledge of the following questions.

1. What is a disciple?
a) A pastor
2
b) A lay member
c) A teacher
d) A believer
e) A follower of Christ
11
f) An evangelist
g) One who makes disciples
21
h) Don't Know

2. Is there any difference between a disciple and a believer?

$\mathrm{R}: \quad \mathrm{Yes}=$
$\mathrm{No}=$

35

3

3. During your Christian life how many new converts have you won for Jesus?
a) 0
25
b) $1-5$
13
c) $5-10$
0
d) More than 10
0

4. Are you presently witnessing to anyone?
a) Yes
16
b) No
22

5. How much time are you spending in reading the Word of God daily?
a) Less than an hour
26
b) An hour
12
c) More than an hour
0

6. How much time are you spending in prayer daily?
a) Less than an hour
30
b) An hour
6
c) More than an hour
2 
7. How often do you come to church?
a) From time to time
8
b) Only on Saturdays
c) All the services
23

8. In a scale from 1 to $\mathbf{1 0}$ what is your participation in the church?

$\begin{array}{lllllllllll}\text { R: } & 1 & 2 & 3 & 4 & 5 & 6 & 7 & 8 & 9 & 10 \\ \text { Score } & 6 & 3 & 0 & 2 & 6 & 3 & 5 & 6 & 0 & 7\end{array}$

9. Do you find it easy to dialogue with others about Christ?
a) Yes
31
b) No
7

10. If you had the opportunity to learn more about how to be a disciple for Jesus, would you attend a discipleship seminar?
a) Yes
38
b) No
0 
Discipleship Seminar

"Go and Make Disciples"

\section{RESULTS \\ Post-Seminar Questionnaire}

\section{Instructions}

Circle or write the appropriate answer that best describes your knowledge of the following questions.

1. What is a disciple?
a) A pastor
4
b) A lay member
0
c) A teacher
0
d) A believer
0
e) A follower of Christ 5
f) An evangelist 0
g) One who makes disciples 20
h) Don't know
0

2. Is there any difference between a disciple and a believer?
$\mathrm{R}$ : $\quad \mathrm{YES}=$
$\mathrm{NO}=$
28
1

3. During your Christian life how many new converts have you won for Jesus?
a) 0
b) $1-5$
16
c) $5-10$
13
d) More than 10
0
0

4. Are you presently witnessing to anyone?
a) Yes
10
b) No
19

5. How much time are you spending in reading the Word of God daily?
a) Less than an hour
b) An hour
16
c) More than an hour
0

6. How much time are you spending in prayer daily?
a) Less than an hour
20
b) An hour
9
c) More than an hour
0 
7. How often do you come to church?
a) From time to time
b) Only on Saturdays
c) All the services

8. In a scale from 1 to 10 what is your participation in the church?

$\begin{array}{lllllllllll}\text { R: } & 1 & 2 & 3 & 4 & 5 & 6 & 7 & 8 & 9 & 10 \\ \text { Score: } 4 & 2 & 1 & 0 & 7 & 0 & 6 & 2 & 2 & 5\end{array}$

9. Do you find it easy to dialogue with others about Christ?
a) Yes
23
b) No
6

10. Did the seminar improve your understanding of discipleship and help you to develop new witnessing skills?
a) Yes
29
b) No 


\section{DISCIPLESHIP SEMINAR \\ "GO AND MAKE DISCIPLES"}

\section{EVALUATION OF THE SEMINAR BY THE PARTICIPANTS}

Please circle the number that you think is most appropriate in how you rate the effectiveness of the seminar.

Key:

1. Very poor

2. Poor

3. Average

4. Good

5. Very good

1. Was the content of each lesson clear to you?

Scale: $1 \quad 2 \quad 3 \quad 4 \quad 5$

2. Was the content of each lesson helpful to your Christian experience?

Scale: $1 \quad 2 \quad 3 \quad 4 \quad 5$

3. Was the presenter clear in his presentation?

Scale: $1 \quad 2 \quad 3 \quad 4 \quad 5$

4. Did the presenter know the material?

Scale: $1 \quad 2 \quad 3 \quad 4 \quad 5$

5. Did the presenter answer the questions properly?

Scale: $1 \quad 2 \quad 3 \quad 4 \quad 5$

6. As a result of what you learned, were you more motivated to work for Jesus?

Scale: $1 \quad 2 \cdot 3 \quad 4 \quad 5$

7. Did the seminar start on time and end on time?

Scale: $1 \quad 2 \quad 3 \quad 4 \quad 5$

8. Was the environment of the seminar in good condition?

Scale: $1 \quad 2 \quad 3 \quad 4 \quad 5$

9. Quality of the seminar as a whole

Scale: $1 \quad 2 \quad 3 \quad 4 \quad 5$

10. Would you recommend this seminar?

Scale: $1 \quad 2 \quad 2 \quad 3 \quad 4 \quad 5$


11. Comments:

a)

b)

c) 


\section{DISCIPLESHIP SEMINAR \\ "GO AND MAKE DISCIPLES" \\ RESULTS \\ EVALUATION OF THE SEMINAR BY THE PARTICIPANTS}

Please circle the number that you think is most appropriate in how you rate the effectiveness of the seminar.

Key:

1. Very poor

2. Poor

3. Average

4. Good

5. Very good

1. Was the content of each lesson clear to you?

Scale:

2

Score:

$\begin{array}{lll}3 & 4 & 5 \\ & 8 & 18\end{array}$

2. Was the content of each lesson helpful to your Christian experience?

Scale: 1

Score

$\begin{array}{llll}2 & 3 & 4 & 5 \\ & 2 & 3 & 21\end{array}$

3. Was the presenter clear in his presentation?

Scale: $1 \quad 2 \quad 3 \quad 4 \quad 5$

Score $\quad 5 \quad 21$

4. Did the presenter know the material?

$\begin{array}{lllll}\text { Scale: } 1 & 2 & 3 & 4 & 5 \\ \text { Score } & & & & 4\end{array}$

5. Did the presenter answer the questions properly?

$\begin{array}{lllll}\text { Scale: } 1 & 2 & 3 & 4 & 5 \\ \text { Score } & & 1 & 5 & 20\end{array}$

6. As a result of what you learned, were you more motivated to work for Jesus?

$\begin{array}{lllll}\text { Scale: } 1 & 2 & 3 & 4 & 5 \\ \text { Score } & & & & 4\end{array}$

7. Did the seminar start on time and end on time?

Scale: $1 \quad 2 \quad 3 \quad 4 \quad 5$

$\begin{array}{llll}\text { Score } & 1 & 7 & 18\end{array}$

8. Was the environment of the seminar in good conditions?

Scale: $1 \quad 2 \quad 3 \quad 4 \quad 5$ 
Score

$1 \quad 12 \quad 13$

9. Qualify the seminar as a whole

Scale:

2

34

Score

323

10. Would you recommend this seminar?

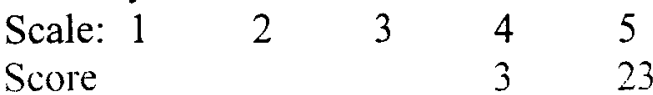

11. Comments:

a) The seminar was excellent.

b) I learned the difference between a disciple and believer.

c) The seminar was very helpful to me.

d) The seminar helped to wake me up regarding my spiritual condition.

e) I would like to learn more about discipleship.

f) We need more seminars like these.

g) The seminar was biblical.

h) The seminar helped me in my spiritual life. It would be good if all church members would come.

i) With the Lord's help, I will try to be a good disciple. 


\section{BIBLIOGRAPHY}




\section{BIBLIOGRAPHY}

Albright, W. F., and C. S. Mann. Matthew. Anchor Bible. Vol. 26. Garden City, NY: Doubleday, 1976.

All About Following Jesus. Disciples of Christ. http://www.allaboutfollowingjesus.org/ disciples-of-christ-faq.htm (accessed February 10, 2009).

Barclay, William. The Gospel of Mark. Buenos Aires, Argentina: Asociacion Editorial La Aurora, 1974.

Barna, George. Data and Trends. Ventura, CA: Barna Research Group, 1998.

Blackaby, Henry. Experiencing the Cross. Sisters, OR: Multnomah, 2005.

Bonhoeffer, Dietrich. The Cost of Discipleship. New York: Touchstone, 1959.

Bounds, E. M. The Weapon of Prayer. New Kensington, PA: Whitaker House, 1996.

Burrill, Russell. Radical Disciples for Revolutionary Churches. Fallbrook, CA: Hart Research Center, 1996.

Cahill, Mark. One Thing You Can't Do in Heaven. RockWall, TX: Biblical Discipleship Publishers, 2004.

Cell Church International. "The Essential of a Cell Church." http://www.cellchurchonline $. c o m /$ default.cfm?nav=qa\&qa $=$ ga\&qa $=5$ (accessed October 17,2008$)$.

Chennattu, Rekha M. Johannine Discipleship as a Covenant Relationship. Peabody, MA: Hendrickson Publishers, 2006.

Cho, Myung Soo. "Christ-centered Discipleship: A Biblical Concept of Religious Education." Ph.D. dissertation, Andrews University, 1990.

Coléman, Robert E. The Master Plan of Evangelism. Grand Rapids, MI: Fleming H. Revell, 1980. 
Comiskey, Joel. "History of the Cell Movement." Ph.D. Tutorial, Fuller Theological Seminary, 1996. http://members.tripod.com/celycecominskey/new page $2 . \mathrm{htm}$ (accessed October 15, 2008).

Conn, Harvie, ed. Theological Perspectives on Church Growth. Phillipsburg, NJ: Presbyterian and Reformed Publishing, 1977.

Culpepper, R. Allan. "The Johannine School: An Evaluation of the Nature of Ancient Schools." SBL Dissertation Series, no. 26. Missoula, MT: Scholars, 1975.

Dewey, Joanna. Mark on Discipleship. Cincinnati, OH: Education and Cultivation Division, 1976.

Dixon, Michael. "Discipleship in 1 Peter as a Model for Contextual Mission." D.Min. dissertation, Southern Baptist Theological Seminary, 1989.

Dossman, Craig A. Sr. From House to House. A New Testament Model for Church Growth. Lincoln, NE: BBMRC, 1994.

Eims, LeRoy. The Lost Art of Disciple Making. Grand Rapids, MI: Zondervan Publishing House, 1978.

"The Essentials of a Cell Church." Cell Church International. http://www.cellchurch.info/ Articles/Cell_models.htm (accessed October 17, 2008).

Foss, Michael W. Power Surge: Six Marks of Discipleship for a Changing Church. Minneapolis, MN: Fortress Press, 2000.

G 12 Revolution."The G 12 Vision," http//g12revolution.com/index.php?option=com_ content\&task=view14\&Itemid=48 (accessed October 15, 2008).

George, Karl. Prepare Your Church for the Future. Grand Rapids, MI: Baker Book House, 1991.

Hill, David. The Gospel of Matthew. London: Marshall, Morgan and Scott, 1972.

Hillmer, Melvyn R. "They Believed in Him: Discipleship in the Johannine Tradition." In Patterns of Discipleship in the New Testament, ed. Richard N. Longnecker, 91. Grand Rapids, MI: Eerdmans, 1996.

Hull, Bill. The Disciple Making Pastor. Old Tappan, NJ: Fleming H. Revell, 1988.

Hunter, Kent R. Foundations for Church Growth: Biblical Basis for the Local Church. Corunna, IN: Church Growth Center, 1994. 
Kaiser, Walter C. "Lamad." Theological Wordbook of the Old Testament. Chicago, IL: Moody, 1980.

Kittel, Gerhard. "Akoloutheo." Theological Dictionary of the New Testament. Grand Rapids, MI: Eerdmans, 1965. 1:213-14.

Kohlenberger, John R. "Mimetes." The Expanded Vine's Expository Dictionary of New Testament Words. Minneapolis, MN: Bethany House, 1984.

Lenski, R. C. H. St. John's Gospel. Minneapolis, MN: Augsburg Publishing House, 1961.

Let us Reason Ministries. "G12 - The Government of 12," http:/www.letusreason.org/ Pent 55.thm (accessed October 15, 2008).

Longnecker, Richard N., ed. Patterns of Discipleship in the New Testament. Grand Rapids, MI: Eerdmans, 1996.

"A Look at G-12." http://www.reachouttrust.org/articles/relatedsubjects/g12.htm (accessed October 15, 2008).

McIntosh, Gary L. Biblical Church Growth. Grand Rapids. MI: Baker Books, 2003.

Melbourne, Bertrand L. Called to Disicipleship, Lessons from the Life of Jesus. Nampa, ID: Pacific Press, 2007.

Meye, Robert P. Jesus and the Twelve. Grand Rapids, MI: Eerdmans, 1968.

Michaelis, Wilhem. "Mimetes." Theological Dictionary of the New Testament. Grand Rapids, MI: Eerdmans, 1965. 4:673.

“Model." Wikipedia Online, http://en.wikipedia.org/wiki/Model (accessed December 18, 2007).

Moorehead, Bob. The Growth Factor. Joplin, MO: College Press, 1991.

Moulton, James Hope, and George Milligan. The Vocabulary of the Greek Testament. Grand Rapids, MI: Eerdmans, 1952.

Nathanail, Paul. "Service." New College Greek and English Disctionary. Lincolnwood, IL: NTC Publishing Group, 1996.

Omartian, Stormie. The Power of a Praying Woman. Eugene, OR: Harvest House Publisher, 2002.

Patte, Daniel. The Challenge of Discipleship: A Critical Study of the Sermon on the Mount as Scripture. Harrisburg, PA: Trinity Press International, 1999. 
Pink, Arthur W. Spiritual Growth. Grand Rapids, MI: Baker Book House, 1971.

Reachout Trust. "A Look at G12." http//www.reachouttrust.org/articles/relatedsubjects/ g12.htm (accessed October 15, 2008).

Rengstorf, Karl H. "Manthano." Theological Dictionary of the New Testament. Grand Rapids, MI: Eerdmans, 1965. 4:406-457.

Rose, Walton H. Sr. "The Use of Small Groups as an Element of Discipleship in the Fairhaven, Flint, Michigan, Seventh-day Adventist Church." D.Min. dissertation, Andrews University, 1996.

Samaan, Philip. Christ's Way of Making Disciples. Hagerstown, MD: Review and Herald, 1999. . Christ's Way to Pray. Hagerstown, MD: Review and Herald, 2006.

Small Groups Articles. "History of the Cell Movement." http//members.tripode.com/ Celycecomiskey/new_page_2.htm (accessed October 17, 2008).

Solid Rock Ministries International, "G12 History." http//www.solidrock12.org/g12.html (accessed October 15, 2008).

Tenney, Merril C. The Gospel of John. The Expositor's Bible Commentary. Vol. 9. Edited by Frank E. Gaebelein and J. D. Douglas. Grand Rapids, MI: Zondervan, 1981.

Tillin, Tricia. Cross + Word, "The Transforming Church (9). " http://www.intotruth.org/ Apostasy/cell-church9.thm (accessed October 15, 2008).

U.S. Census Bureau, Birmingham (city) Alabama. http://quickfacts.census.gov/qfd/states 101/0107000.html (accessed January 21, 2009).

Wagner, Peter. Leading your Church to Growth. Ventura, CA: Regal, 1984.

Watson, David. Called and Committed: World Changing Discipleship. Wheaton, IL: Harold Shaw, 1982.

Webster, William. The Christian. Following Christ as Lord. Carlisle, PA: The Banner of Truth Trust, 1990.

White, Ellen G. Acts of the Apostles. Mountain View, CA: Pacific Press, 1911. 1990 . Colporteur Ministry and Help in Daily Living. Nampa, ID: Pacific Press, 
. The Desire of Ages. Mountain View, CA: Pacific Press, 1940.

. Evangelism. Hagerstown, MD: Review and Herald, 1970.

. God's Amazing Grace. Hagerstown, MD: Review and Herald, 1973.

. The Ministry of Healing. Mountain View, CA: Pacific Press, 1959.

. Testimonies for the Church. 9 Vols. Mountain View, CA: Pacific Press, 1948.

. Welfare Ministry. Hagerstown, MD: Review and Herald, 1952.

Wilkins, Michael James. "The Concept of Disciple in Matthew's Gospel." Ph.D. dissertation, Fuller Theological Seminary, 1986.

. Following the Master: Discipleship in the Steps of Jesus. Grand Rapids, MI: Zondervan Publishing House, 1992.

World Church Statistics. http://www.adventiststatistics.org/view_Summary.asp?FieldAbr $=\mathrm{GC}$ (accessed April 23, 2009). 


\section{VITA}

Name: Ezequiel Osorio

Place and Date of Birth: Guatemala, March 29, 1954

Wife: Maria Gabriela Osorio - married January 29, 1984

Children: Marianela Osorio - born January 4, 1985

Flor de Maria Osorio - born October 30, 1987

Edgar David Osorio - born March 17, 1989

\section{EDUCATION}

1974 High School, Escuela de Comercio, Guatemala

1982 Bachelor of Arts in Theology, Unadeca, Costa Rica

1990 Master in Administration and Leadership, Loma Linda University Extension Costa Rica

1995 Master Divinity Equivalence, Andrews University, Berrien Springs, Michigan

2009 Doctor of Ministry, Andrews University, Berrien Springs, Michigan

\section{WORK EXPERIENCE}

1982 - 1984, District Pastor, Northeast Guatemala

1984 - 1986, District Pastor, Guatemala City, Guatemala

1986 - 1990, Publishing Director, Guatemala Mission, Guatemala

1990 - 2000, Publishing Associate Director. Lake Union, Michigan

2000 - 2006, District Pastor, Mississippi, Gulf States Conference

2006 - Present, District Pastor, Alabama, Gulf States Conference 